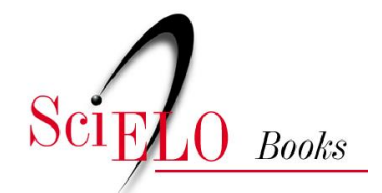

\title{
Psicologia social e pessoalidade
}

\author{
Mary Jane P. Spink \\ Pedro Figueiredo \\ Jullyane Brasilino \\ (orgs.)
}

SPINK, MJP., FIGUEIREDO, P., and BRASILINO, J., orgs. Psicologia social e pessoalidade [online]. Rio de Janeiro: Centro Edelstein de Pesquisas Sociais; ABRAPSO, 2011, 192 p. ISBN: 97885-7982-057-1. Available from SciELO Books $<$ http://books.scielo.org $>$.

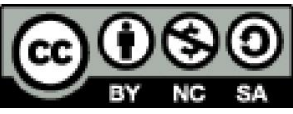

All the contents of this chapter, except where otherwise noted, is licensed under a Creative Commons Attribution-Non Commercial-ShareAlike 3.0 Unported.

Todo o conteúdo deste capítulo, exceto quando houver ressalva, é publicado sob a licença Creative Commons Atribuição Uso Não Comercial - Partilha nos Mesmos Termos 3.0 Não adaptada.

Todo el contenido de este capítulo, excepto donde se indique lo contrario, está bajo licencia de la licencia Creative Commons Reconocimento-NoComercial-CompartirIgual 3.0 Unported. 


\section{Biblioteca Virtual de Ciências Humanas}

\section{PS I C OLOG I A}

SOC I A L

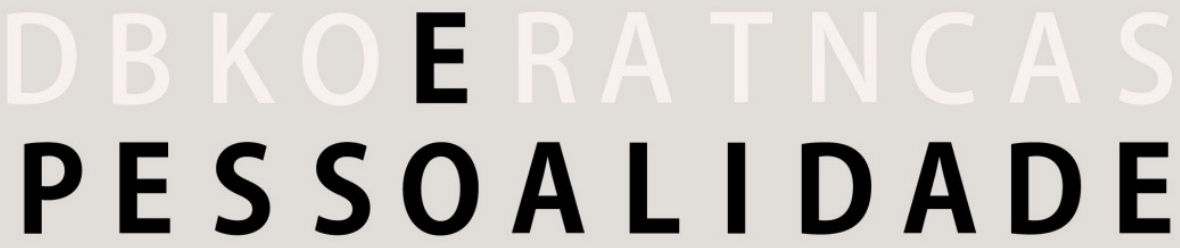

Mary Jane P. Spink

Pedro Figueiredo

Jullyane Brasilino

Organizadores 


\section{Mary Jane P. Spink Pedro Figueiredo Jullyane Brasilino \\ Organizadores}

\section{PSICOLOGIA SOCIAL E PESSOALIDADE}

Centro Edelstein de Pesquisas Sociais ABRAPSO

Rio de Janeiro
Esta publicação é parte da Biblioteca Virtual de Ciências Humanas do Centro Edelstein de Pesquisas Sociais - www.bvce.org

Copyright (c) 2011, Mary Jane P. Spink, Pedro Figueiredo e Jullyane Brasilino (organizadores)

Copyright (C) 2011 desta edição on-line: Centro Edelstein de Pesquisas Sociais e ABRAPSO (Associação Brasileira de Psicologia Social)

Capa: Simon Spink

Nenhuma parte desta publicação pode ser reproduzida ou transmitida por qualquer meio de comunicação para uso comercial sem a permissão escrita dos proprietários dos direitos autorais. A publicação ou partes dela podem ser reproduzidas para propósito não comercial na medida em que a origem da publicação, assim como seus autores, seja reconhecida.

ISBN: 978-85-7982-057-1

Centro Edelstein de Pesquisas Sociais

www.centroedelstein.org.br

Rua Visconde de Pirajá, 330/1205

Ipanema - Rio de Janeiro - RJ

CEP: 22410-000. Brasil

Contato: bvce@centroedelstein.org.br

ABRAPSO (Associação Brasileira de Psicologia Social) www.abrapso.org.br 


\section{Sumário}

Agradecimentos

Apresentação

\section{Pessoa, Indivíduo e Sujeito:}

Notas sobre efeitos discursivos de opções conceituais

Mary Jane P. Spink

Das ontologias e selves:

Singularidades e multiplicidades na noção de pessoa

Pedro Paulo Viana Figueiredo

Ideias do Teatro na formulação da ideia de Pessoa

José Estevam Salgueiro

Juventude(s), modos de subjetivação e violência:

Um diálogo com aportes de Michel Foucault

Beatriz Akemi Takeiti

Relações conjugais violentas:

Processos de subjetivação e suas várias dobras

Jullyane Brasilino

Sujeito na Psicanálise:

$\mathrm{O}$ ato de resposta à ordem social

Patrícia do Prado Ferreira-Lemos

O cuidado em saúde mental e a noção de sujeito:

Pluralidade e movimento 109

Emanoel José Batista de Lima

A questão do reconhecimento:

Axel Honneth e a atualização do modelo conceitual hegeliano a partir

da Psicologia Social de George Herbert Mead. 135

Sheila Ferreira Miranda
A noção de pessoa e a persona corporativa

Heli de Andrade

A transformação através do processo de Coaching

Fernando Fernandes Pimenta

A constituição do $e u$ trabalhador 


\section{Agradecimentos}

Este livro é resultado de discussões realizadas em sala de aula com alunos de doutorado do Programa de Estudos Pós-Graduados em Psicologia Social da Pontifícia Universidade Católica de São Paulo. Mais especificamente, é fruto de reelaborações de textos apresentados como trabalho de conclusão de disciplina alguns dos quais, por opção dos respectivos autores, foram encaminhados, em uma segunda versão, no formato de capítulos para inclusão nessa coletânea. Neles estão presentificadas muitas vozes: de todos e todas que participaram das discussões em sala de aula; da professora que os avaliou como trabalhos de conclusão de disciplinas e dos pareceristas alocados para cada texto. A todos e todas que assim se fazem presentes neste livro, nossos agradecimentos.

Mary Jane Spink Pedro Figueiredo Jullyane Brasilino

São Paulo, setembro de 2011

\section{Apresentação}

Este livro apresenta onze ensaios que exercitam a analítica de nossos modos humanos de viver. Ou seja, não se trata apenas de buscar as várias maneiras de conceituar o ser humano, mas de ver nas palavras/saberes as ações/fazeres que juntos se materializam no efeito de ser pessoa.

Todos os textos são de autoria de doutorandos do Programa de PósGraduação em Psicologia Social da PUC-SP, que aceitaram o desafio de escrever sobre a noção de pessoa ou acerca dos modos de subjetivação que permeavam suas pesquisas. Tal proposta feita por Mary Jane Spink indica não só a sua apreciável capacidade de trabalho na parceria de estudos e pesquisas com temas-estampas tão diversificadas, mas também aponta seu dedo concedendo a bordados tão diferentes uma postura teóricometodológica que procura as condições de produção de algo, isto é, as redes que constituem modos de viver humanos. Sobretudo, os ensaios são reunidos em torno de uma prática que sempre esquadrinha a desfamiliarização crítica do que se torna trabalho de pesquisa.

Podemos falar que são ensaios sobre regimes de ser pessoa que colocam em ação, pessoas jurídicas, pessoas de gênero, pessoas de direitos, pessoas de deveres, pessoas de sexo, etc. Vivemos a era dos regimes em que nos é proposto que cuidemos de nosso "si mesmo" encontrando a "direção ideal" para que possamos suportar o peso da vida. A isso se costuma chamar "qualidade de vida". Com efeito, não faltam dispositivos para nos indicarem os regimes que devemos seguir. São "regimes de verdade" localizados historicamente e constituídos em jogos de saber-poder: "cada sociedade tem seu regime de verdade, sua política geral de verdade" (Foucault, 1985, p.12). ${ }^{1}$ As relações de poder disciplinar estabelecidas em nossas sociedades são positivas, na medida em que instituem e criam espaços, arquiteturas, cidades, sociedades, corpos, além das individualidades: as pessoas, os sujeitos em

\footnotetext{
${ }^{1}$ Foucault, M. (1985) Microfísica do poder. $5^{\mathrm{a}}$ ed. Rio de Janeiro: Graal.
} 
processos de subjetivação. O poder despersonalizado, anônimo, pode personalizar nos tornando alguém-pessoa.

Muitas peças se unem em redes para nos produzir. Uma série de agenciamentos construídos coletivamente nos torna um acontecimento humano, cujo desdobramento é criar a si mesmo. Ser um efeito de si mesmo. Nesse processo, a Psicologia tem sido uma disciplina fundamental, tendo em vista que produz saberes e fazeres, indicando-nos o que e como devemos nos organizar como efeito de si. Propõe a arte de governar a si mesmo, em especial pela via da psicologia da consciência. Consequências inúmeras advêm disso e poderão ser observadas nos ensaios que se apresentam neste livro. Poderíamos dizer que o foco, ao tratar do conceito de pessoa/sujeito, é expor a arte de governar a si mesmo. Governo entendido como certa forma de disposição das coisas dirigidas por um regime de verdade (no caso sobre si).

Como bem nos mostrou Foucault, a partir do século XVI-XVIII, a população foi sendo o objetivo de governo das ciências (políticas, econômicas, estatísticas, etc.). Gerir a população nos mínimos detalhes foi a empreitada humana levada ao extremo na Era Moderna que se estende aos nossos dias. Gerirmo-nos é a palavra de ordem. Desta feita, criamos dispositivos e tecnologias para tal. Mas, sem a menor dúvida, termos voltado a gerir a nós mesmos foi a maior das tarefas humanas, para a qual criamos ciências (humanas). E o que não dizer quando o foco do gerenciamento se fecha em um controle micro?

Usando uma imagem forte: se antes o "bobo" deveria animar a corte para não sucumbir, agora essa estratégia não basta, contudo é preciso incitar a si mesmo, conhecer-se e se responsabilizar pela gerência de sua vida. Mas o Estado paira como o grande irmão que tudo olha: se o seu "eu/si mesmo" não der conta de gerir-se, que chamem a polícia, a Justiça ou o psicólogo (uma espécie de bombeiro/SAMU do eu).

Pelo exposto, a proposta do livro é interessante: coloca-nos diante de diversos movimentos da vida humana. Para onde vamos? Ou como diria
Foucault: "o que estamos fazendo das nossas vidas?”. O objetivo dos ensaios não é revelar finalmente o que somos, mas apontar esses movimentos que nos fazem viver a si e viver com outros, como se fôssemos humanos. Apresentam-se textos com focos epistêmicos distintos, uma diversidade de pontos de partida indagativos, sem hierarquias valorativas e apenas um mote que desencadeou cada escrita: empreender a interpelação à nossa constituição como pessoas/sujeitos, à nossa constituição como singularidades humanas.

Ao fazer esse convite a estudantes que participaram de seu curso no Programa de Pós-Graduação em Psicologia Social da PUC-SP, Mary Jane Spink aposta no projeto de construção descontínua dos saberes humanos; indaga sobre os jogos de verdade que circulam nas nossas academias de ensino, propondo a contínua desfamiliarização de seus sistemas de saberpoder. Ela introduz o livro com o texto "Pessoa, Indivíduo e Sujeito: reflexões sobre efeitos discursivos de opções conceituais". Seus escritos mostram-se bastante oportunos, em virtude do intenso uso (por vezes abuso) que se tem feito de termos como "subjetivação", "subjetividade", "eu", "self", "indivíduo", "pessoa", "consciência de si" e "identidade", em estudos na área da Psicologia Social e afins. É de extrema pertinência a dedicação para dar a conhecer os usos que se fazem dessas categorias, caracterizando domínios de explicação, esclarecendo posturas teórico-metodológicas, esmiuçando possíveis contribuições de autores de referência. A consequência de seu texto é a problematização não apenas de conceitos, mas também da vida das pessoas, suas estratégias de constituição/sujeição e, ao mesmo tempo, de resistência/enfrentamento à naturalização de nossas vidas humanas. Sua viagem inclui passeios pelas obras de Marcel Mauss, George Herbert Mead, Nikolas Rose, Michel Foucault e Rom Harré. Sua dedicação é bem-sucedida porque solicita a um urgente e vigoroso mergulho nas superfícies dessas categorias, convidando-nos a problematizar esse "sujeito" no contemporâneo, fazendo com que nos remetamos às estratégias-implicações advindas desses saberes capazes de criarem modos de viver e, dessa forma, em nossos estudos e pesquisas, o contato com polissemias não nos impeça do cuidado na explicitação dos conceitos que usamos. 
Pedro Paulo Viana Figueiredo escreve o segundo capítulo ("Das ontologias e selves: Singularidades e multiplicidades na noção de pessoa"). Tomando como referência escritos de Nikolas Rose, Ian Hacking, Annemarie Mol e Rom Harré, seu foco é a constituição de pessoas como entidades singulares em práticas de governo do "eu", portanto seu texto se dirige à constituição de nós mesmos como pessoas. Assim, regimes de pessoas (Rose e Hacking) ou maneiras de reger pessoas, que são criados inclusive com a ajuda das disciplinas psi, se desenvolvem de maneira localizada e, por isso, múltipla $(\mathrm{Mol})$, o que torna cada ser humano/pessoa múltiplo, ainda que vivido como singular (Harré).

José Estevam Salgueiro é o autor do terceiro capítulo ("Ideias do Teatro na formulação da ideia de Pessoa"), detendo-se na origem das palavras "persona" e "personagem" e nos usos e feitos desses termos na arte teatral, com o intuito de contribuir para o entendimento da noção de "pessoa". No caso da arte cênica há um "jogo" em que se espera do ator e da cena o reconhecimento de uma veracidade tal como na "vida cotidiana". Salgueiro utiliza-se de escritos de Mead para nos explicar que esse jogo também é fundamental na formação da "pessoa", pois envolve, tal como no teatro, expectativas que se entreanimam e que se fazem em meio a regras. De todo modo, ressalta a importância da "plateia" como participante ativa de um espetáculo, ainda que pareça ser mera espectadora/observadora. Se quisermos, os escritos de Salgueiro podem nos levar à ênfase, não mais no ator como protagonista, mas na interanimação dele com a plateia (a qual inclui os cenários), pois é nela que se constrói a cena.

No quarto capítulo, escrito por Beatriz Akemi Takeiti ("Juventude(s), modos de subjetivação e violência: Um diálogo com aportes de Michel Foucault"), a autora utiliza a noção de modos de subjetivação em Foucault, problematizando o binômio juventude-violência e, assim, expõe como a juventude sendo atravessada por "máquinas sociais" como a própria violência, produz determinados modos de subjetivação no contemporâneo, entendendo essa produção não só como técnica de governo, mas também como possibilidade de se constituírem em movimentos de resistência.
O quinto capítulo assinado por Jullyane Brasilino ("Relações conjugais violentas: Processos de subjetivação e suas várias dobras") se refere a uma pesquisa sua sobre o impacto de dispositivos jurídicos, tais como leis, delegacias e juizados, nas relações de pessoas envolvidas em denúncias de violência conjugal. Chamando esses dispositivos que organizam e controlam as relações conjugais de "judicalização", a autora centra o foco do seu texto na noção que orienta sua pesquisa, qual seja, a de pessoa. Conclui que não se trata de usar o conceito de pessoa como se constituísse per saecula saeculorum um ser (humano) dotado de uma essência universal, mas de considerar o conceito tão volátil quanto os regimes que constituem o ser humano em diversificados modos de viver, entendidos com base no conceito de dobra desenvolvido pelo filósofo francês Gilles Deleuze. Portanto, pessoa sempre seria o efeito de composição de forças, práticas e relações, criando fluxos diversos de modos de vida.

No sexto capítulo, Patrícia do Prado Ferreira-Lemos ("Sujeito na Psicanálise: $\mathrm{O}$ ato de resposta à ordem social") aborda a noção de sujeito que circula na psicanálise lacaniana diferenciando-a da "psicologia do eu". Demonstra que o sujeito é constituído na medida em que entra na "ordem social", em virtude de ser "desamparado" e nascer precisando de cuidados. Esse processo de constituição do sujeito ocorre porque ele é introduzido no campo simbólico que estrutura a vida humana mediada pela linguagem. $\mathrm{O}$ sujeito emerge em "tropeços" que aparecem nos lapsos, atos falhos, indicando que o sujeito sobre o qual se ocupa a Psicanálise é atrelado à concepção de inconsciente, assim, o Outro (social) está em mim e não permite que eu possa me delimitar de forma definitiva, visto que ele/outro também é simbólico e campo da linguagem. A linguagem, por sua vez, não traduz, mas é um efeito em cada um de nós, o qual nos constitui num movimento inconsciente de inscrever no Outro (Social) nossos desejos sempre fluidos, porque criativos.

O sétimo ensaio foi escrito por Emanoel José Batista de Lima ("O cuidado em saúde mental e a noção de sujeito: Pluralidade e movimento"). Fundamentando-se em sua experiência em Centros de Atenção Psicossocial 
(CAPS), versa sobre a temática do Cuidado em Saúde Mental no âmbito da Reforma Psiquiátrica. Conclui que, ao invés desses espaços se tornarem substitutos dos tradicionais hospitais psiquiátricos, mantêm práticas que repõem a cultura manicomial e reativam processos de segregação. Sob essa ótica, articula essa situação com a permanência de relações de assujeitamento, mantidas em jogos de poder-saber (Foucault), tutelados ainda a um saber psiquiátrico, cujos efeitos são intervenções baseadas em racionalidades biologicistas, em que os usuários do serviço são estigmatizados em uma concepção de sujeito sem potencialidades.

O oitavo ensaio foi produzido por Sheila Ferreira Miranda (“A questão do reconhecimento: Axel Honneth e a atualização do modelo conceitual hegeliano a partir da Psicologia Social de George Herbert Mead"). A autora toma por base as reflexões de Axel Honneth sobre posturas de Hegel e George Herbert Mead que lhe permitiram a construção da Teoria do Reconhecimento, criticando o conceito de "psíquico" que permeou o início da Psicologia (atrelado à consciência entendida como interiorização de objetos estáticos e dados naturalmente). Por fim, detendo-se mais nos conceitos de "Eu, Mim e Outro Generalizado" desenvolvidos por Mead, chega à tese de Honneth de que o conflito compõe o "principal motor" da vida social, o qual gera negociações e operações interpretativas diversas advindas das relações de reconhecimento (intersubjetivo).

Heli de Andrade escreveu o nono capítulo ("A noção de pessoa e a persona corporativa"). Neste ensaio, o autor usa como ponto de partida o conceito de "persona corporativa". Utilizando escritos de Nikolas Rose, Michel Foucault e George Mead, mostra que o "mundo corporativo" cria estratégias e diretrizes formais e informais que constituem "tecnologias de subjetivação" que dão aos profissionais, que galgam cargos importantes em uma organização, a ilusão de que são os próprios guias de sua carreira quando seguem os objetivos da organização. Assim, a sujeição, a obediência e o medo de ser excluído do grupo, constroem a pessoa corporativa.

No décimo capítulo ("A transformação através do processo de Coaching"), Fernando Fernandes Pimenta apresenta o relato de um processo de coaching, e tendo como referências a identidade-metamorfose de Antônio da Costa Ciampa e o conceito de self de George Mead, tenciona entender o processo em que uma pessoa se constitui à medida que "torna-se objeto para si mesma", o que só é possível em decorrência de "outros generalizados".

Por fim, temos o texto de Antônio Fernando Gomes Alves ("A constituição do eu trabalhador") que se apoia na concepção marxista sobre a centralidade do trabalho na vida humana (inclusive tida como a atividade responsável pela diferenciação entre seres humanos e animais). Para discorrer sobre o que chama de "eu trabalhador" nos dias atuais em que há mudanças relevantes nas relações trabalhistas e nos modos de produção, o autor ressalta que ainda temos um trabalho alienado, acrescido da "instabilidade", por causa das substituições da mão de obra humana por máquinas e, mais ainda, porque estimula o conhecimento/qualificação individual acirrando a competitividade.

Fica o convite para nos debruçarmos em textos tão diferentes, mas com um mesmo nó que os enreda, que os faz rede. Os fios desta rede não se atam em uma ponta final, mas nos remetem a um novo percurso que é a investigação das pesquisas desses doutorandos que construíram estes ensaios, pois lá, certamente, encontraremos mais questões a nos aguçarem. Ademais nos remetem a continuar acompanhando a produção de Mary Jane em busca de um capítulo seguinte, ainda não escrito, a interpelar nossos modos de viver. Por ora, um livro que:

Mistura os tons... acerta... desacerta... Sempre em busca de nova descoberta, Vai colorindo as horas quotidianas... (Mário Quintana)

Ricardo Pimentel Méllo Fortaleza, setembro de 2011 


\section{Pessoa, Indivíduo e Sujeito: Notas sobre efeitos discursivos de opções conceituais}

\section{Mary Jane P. Spink ${ }^{1}$}

$\mathrm{M}$

uitas vezes, no campo da Psicologia Social, partimos do pressuposto de que as experiências de quem somos são constituídas por meio de nossas vivências em sociedade. Falamos confortavelmente sobre "processos de subjetivação" e, a despeito de possíveis diferenças na escolha de autores com os quais trabalhamos (Mead, Vygotsky, Foucault, Freud, Berger e Luckmann, etc.), entendemos que há distintos posicionamentos nesses processos: somos alguém para outros significativos; somos alguém para instâncias que disciplinam a vida social; somos alguém para nós mesmos. Enfim, somos; temos a experiência de termos (ou sermos) um "eu"; somos porque pensamos (Descartes diria: penso, logo sou!). Para falar dessa experiência singular de processos de subjetivação, adotamos o termo inglês self (ou selves, no plural), traduzido como "eu", ou nos referimos à consciência de si e à identidade. Ou seja, não temos problemas semânticos quando se trata de falar de nossas experiências de sermos "quem somos".

Porém, temos certa dificuldade de nomear esse ser que somos quando teorizamos a respeito da vida em sociedade e, nesse âmbito, nem sempre tomamos alguns cuidados no uso de nossas categorias. Por exemplo, incorporando o gênero de fala próprio aos manuais de metodologia, falamos de sujeitos, quando nos referimos aos "participantes" de nossas pesquisas. Por suas conotações "ideológicas", procuramos evitar o uso da palavra indivíduo, mas a deixamos escapar em seus múltiplos sentidos: individualmente, para nos referirmos a cada um de um grupo; individualismo para nos reportarmos a modos de vida pouco solidários. E pessoa? No caso da Psicologia Social, não seria este mais um termo a ser considerado dentre

\footnotetext{
${ }^{1}$ Bolsista de Produtividade em Pesquisa do CNPq - Nível 1A.
}

as muitas possibilidades de falarmos de quem somos e de quem são os outros que compartilham, por querer ou sem querer, de nossas vidas?

Desse modo, explorar as possibilidades de uso psicossocial do termo pessoa, sugestão que deu origem ao livro em que se insere este texto, foi o desafio que nos levou a propor esse assunto como tema de disciplina do curso de doutorado em Psicologia Social, na Pontifícia Universidade Católica de São Paulo, ministrado em 2010.

Iniciaremos, pois, esta reflexão, situando os usos do termo "pessoa" no contexto da Antropologia e, tomando por base o texto de Marcel Mauss (2003), discutiremos algumas dicotomias que, às vezes inadvertidamente, atravessam muitos de nossos discursos. Seguiremos abordando a opção de George Herbert Mead (1969) pelo termo self, ${ }^{2}$ de modo a destacar os esforços desse protopsicólogo social (Mead era filósofo e lecionava em um curso de Sociologia) para situar a consciência de si em uma perspectiva que alia processos comunicativos (a Filosofia do Ato) e suportes sociais e biológicos sustentados pelo evolucionismo. Abandonando temporariamente as vertentes de pessoalidade, passaremos à emergência da categoria moderna de indivíduo, fundamentando-nos nas discussões apresentadas por Nikolas Rose $(1998 ; 2001)$ a respeito das contribuições da Psicologia aos processos de individualização. Apoiada em Michel Foucault (2005), essa discussão permite passar ao nosso próximo tema, a categoria "sujeito" na interface entre processos de objetivação e subjetivação. O paradoxo que assim se instala será abordado por meio do que consideramos ser uma perspectiva integradora: os múltiplos selves propostos por Rom Harré (1998). Não pretendemos chegar a uma conclusão sobre qual conceito padrão deveríamos adotar para nos referirmos a esse ser que somos no âmbito da Psicologia Social que se quer crítica. Mas esperamos poder suscitar o desafio de, pelo menos, entender as implicações históricas, sociais, políticas, existenciais, éticas, dentre muitas

\footnotetext{
${ }^{2}$ Traduzido, em português, como "eu", a despeito de este termo não ter a mesma conotação reflexiva de self.
} 
outras, da escolha dos termos que usamos para falar do ser que somos, a fim de não cairmos na armadilha da transformação de nossas produções sociais em "entidades". Afinal, como aponta Harré (1998, p.5), "Criamos uma maneira de falar sobre elas por meio de substantivos, justamente a forma gramatical que a fala sobre entidades usa".

\section{A noção de "pessoa" na Antropologia: as dicotomias introduzidas por Marcel Mauss}

Embora problemática, a noção de pessoa na Antropologia Social é um ponto de partida conveniente para situar o debate sobre algumas dicotomias que teimam em permear nossa compreensão sobre esse ser que somos. E, de maneira recorrente, pelo menos na Antropologia, a referência fundamental para o entendimento dessas tensões é o texto de Marcel Mauss, Uma categoria do espírito humano: a noção de pessoa, a de "eu", publicado em $1938 .^{3}$

No referido texto, Mauss adota uma perspectiva evolutiva. Como ele mesmo afirma, a intenção

é vos oferecer, bruscamente, um catálogo das formas que a noção adquiriu em diversos pontos, e mostrar de que maneira ela acabou por ganhar corpo, matéria, forma, arestas, e isto até nossos tempos, quando ela finalmente tornou-se clara, nítida, em nossas civilizações (nas ocidentais, muito recentemente) e não ainda em todas (2003, p.370)

Mais especificamente, Mauss busca demonstrar "o quanto é recente a palavra filosófica 'Eu', como são recentes a 'categoria do Eu', 'o culto do Eu' (sua aberração) e o respeito ao Eu - em particular, ao dos outros” (2003, p.271).

Segundo Marcio Goldman (1999), Mauss tentou aplicar a hipótese durkheimiana de uma história social das categorias do espírito humano no nível das concepções acerca da própria individualidade. "Trata-se de

\footnotetext{
${ }^{3}$ Publicado no Journal of the Royal Anthroplogical Institute, Londres.
}

mostrar como, a partir de um fundo primitivo de indistinção, a noção de pessoa que conhecemos e à qual atribuímos erroneamente existência universal, se destaca lentamente de seu enraizamento social para se constituir em categoria jurídica, moral e mesmo lógica" (Goldman, 1999, p.22). E com essa intenção, nos leva a passear pelos vários estágios utilizados para elaborar a noção de pessoa.

Primeiramente, por meio de relatos sobre os pueblos, os indígenas do noroeste norte-americano e os nativos da Austrália, Mauss introduz uma primeira (e talvez mais primitiva) maneira de situar o lugar das pessoas. Segundo sua interpretação, “(...) um imenso conjunto de sociedades chegou à noção de personagem, de papel cumprido pelo indivíduo em dramas sagrados, assim como ele desempenha um papel na vida familiar" (Mauss, 2003, p.382).

Segue situando a persona latina, estágio em que a noção não se refere apenas a um elemento da organização social, mas a um fato fundamental de direito: o fim do direito do pater de matar seus filhos; o estabelecimento do direito a ter um nome, prenome, sobrenome. Essa compreensão possibilitou a emergência da pessoa como fato moral, ressignificação que tem muito a ver com os estoicos "cuja moral voluntarista, pessoal, podia enriquecer a noção romana de pessoa, e mesmo se enriquecer ao mesmo tempo em que enriquecia o direito". Para Mauss,

Tudo soará de outro modo entre os clássicos latinos e gregos da moral (século II a.C a século IV d.C): será tão somente persona e, o que é fundamental, acrescenta-se cada vez mais um sentido moral ao sentido jurídico, um sentido de ser consciente, independente, autônomo, livre, responsável. (...) às funções, honrarias, cargos e direitos, acrescenta-se a pessoa moral consciente (Mauss, 2003, p.390).

Em suma, a "consciência de si” tornou-se o apanágio da pessoa moral, mas "foram os cristãos que fizeram da pessoa moral uma entidade metafísica, depois de terem sentido sua força religiosa" (Mauss, 2003, p.392), sendo nossa noção de pessoa ainda hoje, fundamentalmente, a noção cristã. 
No entanto, nessa perspectiva evolutiva, a noção de pessoa haveria ainda de sofrer outra modificação ao adquirir seu estatuto de ser psicológico. De acordo com Mauss:

A noção de pessoa haveria de sofrer ainda uma outra transformação para tornar-se o que ela tornou-se há menos de um século e meio, a categoria do Eu. Longe de ser a ideia primordial, inata, claramente inscrita desde Adão no mais fundo de nosso ser, eis que ela continua, até quase o nosso tempo, lentamente a edificar-se, a clarificar-se, a especificar-se, a identificar-se com o conhecimento de si, com a consciência psicológica (Mauss, 2003, p.394).

Contudo, não foi por meio do pensamento discursivo, o Cogito ergo sum de Descartes, que o problema da consciência encontrou sua solução, mas em decorrência dos movimentos sectários dos séculos XVII e XVIII que iriam influenciar a formação do pensamento político e filosófico. Foram eles que propuseram as questões da liberdade individual, da consciência individual, do direito de comunicar-se diretamente com Deus e de ter um Deus interior. Na interpretação de Mauss, é com Kant e, sobretudo com Fichte, que a categoria do "Eu" se torna condição da consciência e da ciência.

Sublinhando essa perspectiva evolutiva, Goldman (1999) considera que, para Mauss, essa autonomização progressiva do indivíduo, em face da totalidade social, só poderia ser entendida como um efeito do desenvolvimento da própria sociedade que, ao se diferenciar internamente, permitiria a particularização concomitante de seus membros. Essa trajetória, que nos leva das noções de pessoa à categoria do "Eu", absorve algumas oscilações que são de particular interesse para a compreensão de como esta foi incorporada à Psicologia Social.

Uma primeira oscilação concerne à oposição entre posturas universalistas e relativistas. Assim, de um lado, Mauss parte da conjectura de que a percepção de individualidade, de singularidade, é característica universal dos seres humanos. Nas palavras dele: “(...) é evidente, sobretudo para nós, que nunca houve ser humano que não tenha tido o senso, não apenas de seu corpo, mas também de sua individualidade espiritual e corporal ao mesmo tempo" (Mauss, 2003, p.371). Porém, para Goldman, "Sob a evolução quase linear da noção de pessoa, o que acaba sendo revelado é a variação das representações sociais em torno do indivíduo humano" (Goldman, 1999, p.23). Ou seja, as noções de pessoas, vistas no plano horizontal (e não histórico-linear como propôs Mauss), são construções culturalmente variáveis. Nessa oscilação, situa-se o debate sobre o que Boaventura Santos (2006) denominou de globalismo localizado: a projeção da noção de pessoa ocidental sobre as outras sociedades.

O texto de Mauss abre o debate também para um segundo tipo de oscilação: aquela que opõe a pessoa como ser social ao indivíduo como ser biológico. Trata-se, ainda, da contraposição entre universais e particulares, situando o foco da variação em um referente fixo, infraestrutural, biopsicológico. Foi essa a orientação adotada na tradição antropológica britânica. Por exemplo, de acordo com Goldman (1999), Radcliffe-Brown distingue "indivíduo" e "pessoa" com base na diferenciação entre os aspectos biológicos (que correspondem ao indivíduo, foco dos estudos de biólogos e psicólogos) e sociais que remetem às posições ocupadas por indivíduos na rede de relações sociais concretas, foco da Antropologia e da Sociologia. Todavia, o perigo desse homem duplex (ser biológico + ser social) é que não há flexibilidade para compreender o modo pelo qual o grupo estudado concebe tanto a realidade individual como a posição de pessoa no grupo. Acaba conceituando os grupos à imagem e semelhança dos indivíduos, projetando, assim, as concepções ocidentais de indivíduo aos demais grupos.

Tal percepção nos leva às posições que trabalham a noção de indivíduo na contraposição entre ideologia individualista e formações sociais de tipo holista, caminho percorrido, por exemplo, por Louis Dumont (1992). Na interpretação de Goldman (1999, p.28), "Essas posturas permitem abandonar qualquer forma de evolucionismo, levando a perceber que nossas próprias concepções dependem de uma transformação sociopolítica complexa, não de um evolucionismo qualquer".

Sob essa ótica, a Psicologia, como campo de saber-poder, tem, como discutiremos, papel relevante nesse processo de individualização, aspecto 
fundamental das estratégias de governamentalidade na sociedade de controle, as quais possibilitarão falar de sujeitos, seja na perspectiva de assujeitamento, seja na vertente da resistência por meio das técnicas de cuidado.

Essa breve introdução ao pensamento de Mauss certamente não resolve a questão sobre a qual nos propusemos a refletir neste texto: que nomeações devemos usar para nos referirmos, em termos psicossociais, a quem somos, e que efeitos esses usos têm? Porém, nos é útil por situar alguns dos debates que poderão servir de guias para refletir sobre os usos dos termos "pessoa", "self", "indivíduo", "sujeito". Seguiremos, assim, as pistas oferecidas por Marcio Goldman de modo a tensionar os efeitos do uso desses termos.

\section{A opção por self nas teorizações de George Herbert Mead: conciliando evolucionismo com as vicissitudes dos processos de comunicação}

Mauss situa a variação da ideia de pessoa em um enquadre evolutivo. Talvez seja possível entender tal postura a partir do impacto que a teoria da evolução de Charles Darwin teve na produção de conhecimento do final do século XIX e começo do século XX. Afinal, Mauss, assim como George Herbert Mead, na voz de quem apresentamos a perspectiva psicossocial, nasceram respectivamente em 1872 e 1863. O livro de Darwin, A origem das espécies, foi publicado em 1859, e seguido por duas outras obras de expressiva influência: A descendência do Homem e Seleção em relação ao sexo (1871) e A expressão da emoção em Homens e Animais (1872).

Mead, ao fazer suas considerações sobre o self, assume explicitamente uma postura evolucionista. O primeiro capítulo da coletânea de textos de Mead, organizada por Anselm Strauss, publicada originalmente em 1956 (Strauss, 1969), intitula-se "A evolução se torna uma ideia geral" e tem por complemento o segundo capítulo que trata do paradoxo entre processos fluidos, evolutivos e ordem social. Tomando por foco o processo, Mead faz a opção pelos idealistas românticos, sobretudo por Hegel, em contraposição a Kant, pois, para ele, o self envolve uma relação dinâmica entre sujeito e objeto, e ambos, sujeito e objeto, estão em movimento. Por outro lado, não é possível haver sujeito sem objeto. Antecipando discussões contemporâneas sobre ontologia (vide, por exemplo, Mol, 1999), Mead afirma:

O sujeito de fato envolve o objeto para que possamos ter consciência. Mas não nos é tão inevitável reconhecer que o sujeito é essencial para que haja um objeto presente. De acordo com nossa concepção de ciência, ${ }^{4}$ o mundo surgiu durante milhões de anos, apenas nos últimos momentos dos quais existiram formas de vida; e apenas nos últimos segundos desses momentos existiram quaisquer formas humanas. $\mathrm{O}$ mundo estava presente muito antes de apareceram os sujeitos. O que fazem os idealistas românticos é pressupor que para que esses objetos estejam presentes há que haver um sujeito. De certo modo poderíamos dizer que isso reflete o dogma filosófico que o mundo não poderia estar presente a não ser se criado por um ser consciente. Mas esse problema é mais profundo que um dogma filosófico. Trata-se do pressuposto que a própria existência de um objeto, como tal, envolve a existência de um sujeito para o qual é um objeto (Mead, 1969, p.17).

Em resumo, Mead aplica a ideia de evolução também aos objetos sejam eles humanos ou não humanos (p.218), ou seja, ao mundo tal como o vivenciamos. Seguindo Spencer, aplica as noções darwinistas à própria sociedade, incluindo aí as materialidades e as socialidades. Conforme ele afirma: "As sociedades se desenvolvem tal como as formas animais se desenvolvem, ajustando-se aos problemas que encontram à sua frente" (p.24). Em suas palavras,

O que estou procurando fazer é conectar todo o processo evolutivo com a organização social em sua expressão mais complexa, e como aquilo em que exatamente se originam os indivíduos através de cujos processos-de-vida [essa organização social] funciona, dando origem precisamente aos elementos que estão envolvidos no desenvolvimento de selves (Mead, 1969, p.30).

\footnotetext{
${ }^{4}$ Mead se refere à concepção tradicional de ciência.
} 
Tomando por base Comte e, mais especificamente Spencer, Mead se refere à sociedade a partir da metáfora do organismo, com o objetivo de pontuar a influência dos processos evolutivos. É o estudo do organismo social que dá margem à emergência das Ciências Sociais e, particularmente, da Sociologia. Mas, paralelamente ao interesse no estudo da organização social, desenvolve-se também o estudo das experiências individuais. E então, Mead adentra a problemática dos selves e da mente.

Para ele, o self emerge por meio da habilidade de assumir a atitude do grupo ao qual pertence. Além disso, a estrutura da sociedade está impregnada nos hábitos sociais e, na medida em que introjetamos esses hábitos, é que nos tornamos selves.

Esse desenvolvimento de uma forma que é capaz de se comunicar com outros, que assume atitudes dos membros do grupo, que fala consigo mesmo como fala com outros, que importa para sua própria vida essa conversação e cria um fórum interno no qual testa o processo que levará a efeito, e assim o trás para consideração pública com a vantagem desse ensaio anterior, é especialmente importante (Mead, 1969, p.33-34).

O processo de desenvolvimento do self tem início a partir da capacidade de a criança assumir diferentes papéis ao brincar e, a seguir, aprender tais papéis no contexto das regras de um jogo. A diferença fundamental dessas etapas é que, no contexto do jogo, a criança tem de aprender a atitude de todos que estão envolvidos nele. É assim que Mead chega à noção de "outro generalizado": a comunidade organizada, o grupo social no qual se está inserido. Para ele, os processos complexos de cooperação social só serão possíveis se cada indivíduo nela incluído puder adotar as atitudes genéricas dos outros como referência, e direcionar seu comportamento de acordo.

Esse outro generalizado é de dois tipos: um, mais concreto, se refere aos grupos de pertença, isto é, clubes, partidos políticos, etc. O outro, mais genérico, é constituído de classes ou agrupamentos mais amplos - como todos os que estão em débito financeiro. E a pertença a esses grupos mais amplos possibilita um sem número de relações sociais, mesmo que indiretas. Assim, o mais amplo desses grupos abstratos é o de pertença a uma comunidade linguística, "uma relação que emerge do funcionamento universal dos gestos como símbolos significantes no processo social genérico de comunicação humana" (Mead, 1969, p.222).

É apenas por meio dessa capacidade de absorver a atitude do outro generalizado em relação a si mesmo que se pode pensar. Logo, o pensamento, para Mead, é um processo de conversação consigo mesmo, quando se assumem as atitudes comuns do grupo e quando os símbolos usados são comuns ao grupo, de modo que o sentido seja compartilhado. É um processo de comunicação decorrente da participação na experiência de outras pessoas. Portanto, o self é uma experiência social que só existe num grupo de indivíduos sociais, proveniente do processo evolutivo tal como resultam outras formas biológicas.

Trata-se de uma forma biológica que pode cooperar com outros por meio de símbolos significativos; entender as atitudes de outros e responder a elas por causa de desenvolvimentos no sistema nervoso central. O que Mead quer demonstrar, então, é que a evolução da "mente", assim como a das instituições sociais, é uma evolução social, o que possibilita a complexidade das soluções encontradas nas sociedades de humanos. Em síntese, embora as teorizações de Mead tenham por foco os processos, ele considera não ser possível ter processos sem alguma estrutura, ou seja, sem uma forma na qual o processo possa se expressar. Evolução da mente, no plano biológico, e evolução social andam de par em par.

Até que ponto, pois, a noção meadiana de self se aproxima da noção maussiana de pessoa? A ideia de evolução que norteia suas teorizações parece distinta: vista num plano histórico longitudinal, as sociedades, no texto de Mauss, evoluem da personagem em dramas que extrapolam as especificidades locais para a categoria de "Eu" contemporânea. Como Mead, Mauss parte do pressuposto de que as formações sociais também são processuais, também evoluem. Porém, talvez por adotar uma perspectiva de tempo longo, Mauss não tem por foco os processos de desenvolvimento 
dessa experiência de Eu, deixando-a restrita à instauração de uma experiência do Eu, limitada ao indivíduo.

Nas teorizações de Mead, a evolução nos níveis da biologia e das sociedades é mero pressuposto. Seu foco é o processo de desenvolvimento do self na relação que se estabelece com os outros generalizados. Abre-se o flanco para universalismos apenas no que se refere à utilização de símbolos na comunicação, pois os "outros" - mais concretos (os grupos de pertença) ou mais genéricos (grupos mais abstratos, como a mera pertença a uma comunidade linguística) - são bastante diversos, o que nos leva a concluir que os selves são socialmente contextualizados e, portanto, variáveis de grupo para grupo.

\section{Individualizando nossos selves: a contribuição da Psicologia à construção das categorias de indivíduo e identidade}

Mead, a bem dizer, teve pouca influência na formatação da Psicologia do final do século XIX e início do século XX. ${ }^{5}$ Com formação filosófica influenciada pelo idealismo alemão, Mead estava mais afinado com as ideias de Hegel do que com as de Descartes. Mas é em Descartes que se ancorava o positivismo que embasou a emergente "ciência" psicológica. Desse modo, segundo Rob Farr (2008), ele foi considerado por demais metafísico e incompatível com uma disciplina que se queria científica. Assim, na direção contrária à reflexão sobre o "Eu", a partir da relação entre experiências pessoais e vida em sociedade, a Psicologia contribuiu, principalmente, para a singularização desses selves na modalidade das técnicas de disciplinarização.

Nikolas Rose, no livro "Inventando nossos selves" (1998), aborda a história do regime contemporâneo do Eu, por meio de uma genealogia da

\footnotetext{
${ }^{5}$ Embora suas contribuições tenham sido reconhecidas e incorporadas na segunda metade do século XX nas correntes associadas à Sociologia (a chamada Psicologia Social Sociológica), tornando-se referência obrigatória no que concerne à importância da sociedade na formatação do self.
}

subjetivação. Caracteriza a escolha dessa estratégia metodológica indicando o que não pretende fazer: Não se trata de uma história das ideias sobre pessoa por meio de análises de como isso se deu na Filosofia, na Literatura, nas Artes; nem de uma história da pessoa considerada como uma entidade psicológica. O foco está em como diferentes épocas produziram humanos com distintas emoções, crenças, patologias. Seguindo as trilhas inauguradas por Michel Foucault:

Essa genealogia tenta descrever as formas pelas quais esse moderno regime do eu emerge não como o resultado de um processo gradual de esclarecimento, no qual os humanos, ajudados pelos esforços da ciência, acabam, finalmente, por reconhecer sua verdadeira natureza, mas a partir de uma série de práticas e processos contingentes e definitivamente menos refinados e menos dignos (Rose, 2001, p.35).

O foco não é, portanto, a história da pessoa, mas das práticas que localizam os seres humanos em regimes de pessoa: as linguagens de pessoalidade, a variedade de normas, técnicas e relações de autoridade no interior das quais essas linguagens têm circulado. Por conseguinte, uma genealogia que pode seguir diversas trajetórias (Rose, 2001, p.37):

- Onde, como e por quem, certos aspectos do ser humano se tornam problemáticos?

- Que meios têm sido inventados para governar o ser humano?

- A quem se concede - ou quem reivindica - a capacidade de falar de forma verdadeira sobre os humanos, sobre sua natureza e seus problemas, e o que caracteriza as verdades sobre as pessoas às quais se concede tal autoridade?

- Que formas de vida constituem as finalidades, os ideais ou os exemplares dessas diferentes práticas de ação sobre as pessoas?

- Como esses procedimentos para regular as capacidades das pessoas se ligam a objetivos morais, sociais ou políticos mais amplos, concernentes às características indesejáveis e desejáveis das populações, da força de trabalho, da família, da sociedade? 
Cada uma dessas direções da investigação realizada por Rose foi inspirada na obra de Michel Foucault, em particular nas questões relacionadas à ciência do governo. Cabe destaque, pois, nesse contexto, as reflexões de Foucault sobre governamentalidade.

Foucault introduziu a noção de governamentalidade para se referir a uma forma de governo que tem a população como foco. Trata-se da passagem de uma arte de governo - um regime dominado pela estrutura da soberania - para uma ciência política - um regime dominado pelas técnicas de governo. Tal passagem ocorreu no século XVIII e teve como disparador a ideia de população.

A longa trajetória que leva da arte de governo à ciência política incluiu uma transformação fundamental no direito político, processo que teve início no século XVII, com a introdução das tecnologias disciplinares, essencialmente centradas nos corpos individuais. A partir da metade do século XVII, essa forma de lidar com a vida passou a ser complementada por uma nova tecnologia que, segundo Foucault, não excluía a técnica disciplinar, mas que a embutia e a modificava parcialmente e que, sobretudo, iria utilizá-la, implantando-se de certo modo nela, e incrustando-se efetivamente graças a essa técnica disciplinar prévia. Nesse enquadre, a disciplina não desapareceu, mas se tornou ainda mais fundamental.

Quanto à disciplina, ela também não é eliminada. Claro, sua organização, sua implantação, todas as instituições dentro das quais ela havia florescido no século XVII e no início do século XVIII (as escolas, as fábricas, os exércitos), tudo isso fazia corpo [com] e só se compreende pelo desenvolvimento das grandes monarquias administrativas, mas nunca, tampouco, a disciplina foi mais importante e mais valorizada do que a partir do momento em que se procurava administrar a população - e administrar a população não quer dizer simplesmente administrar a massa coletiva dos fenômenos ou administrá-los simplesmente no plano dos seus resultados globais; administrar a população quer dizer administrá-la igualmente em profundidade, administrá-la com sutileza e administrá-la em detalhe (Foucault, 2008, p.142).
Nesse contexto é que a Psicologia trouxe sua singular contribuição às estratégias de governamentalidade, as tecnologias de individualização. Os saberes psi não eram os únicos a contribuir para a elaboração de técnicas de conduta de si, sendo muitas as possíveis exigências: de relacionar-se consigo mesma epistemologicamente (conheça a si mesmo), despoticamente (controle a si mesmo) ou de outras formas (cuide de si mesmo). Todas essas exigências, como sugere Rose (2001, p.41), "são sempre praticadas sob a autoridade real ou imaginada de algum sistema de verdade e de algum indivíduo considerado autorizado, seja esse teológico e clerical, psicológico e terapêutico, ou disciplinar e tutelar". Houve, portanto, uma proliferação de expertise em uma diversidade de campos. Porém, Rose argumenta que a unificação desses regimes de verdade tem muito a ver com um saber específico sobre o ser humano, qual seja, o das disciplinas psi.

As disciplinas "psi”, em parte como consequência de sua heterogeneidade e falta de um paradigma único, adquiriram uma peculiar capacidade penetrativa em relação às práticas para a conduta da conduta. Elas têm sido não apenas capazes de fornecer toda uma variedade de modelos do eu, mas também de fornecer receitas praticáveis para a ação em relação ao governo das pessoas, exercido por diferentes profissionais, em diferentes locais. Sua potência tem sido aumentada ainda mais por sua capacidade para suplementar essas qualidades praticáveis com uma legitimidade que deriva de suas pretensões a dizer a verdade sobre os seres humanos. Elas se disseminaram rapidamente, por meio de sua pronta traduzibilidade, por programas para remoldar os mecanismos de auto direção dos indivíduos, estejam esses na clínica, na sala de aula, no consultório, na coluna de conselhos das revistas ou nos programas confessionais da televisão. É, obviamente, verdade que as disciplinas "psi" não são particularmente admiradas pelo público e seus praticantes são frequentemente objeto de ironia. (Rose, 2001, p.46).

Uma maneira de entender o modo de funcionamento das ciências psicológicas e suas relações com as transformações sociais, políticas e éticas é por meio de suas funções como técnicas de disciplinarização da diferença dos seres humanos, "individualizando humanos por meio de classificações, calibrando suas capacidades e condutas, inscrevendo e 
registrando seus atributos e deficiências, gerenciando e utilizando sua individualidade e variabilidade" (Rose, 1998, p.105). Mediante essas técnicas, a Psicologia responde a dois problemas suscitados pelas instituições do final do século XIX e no início do XX (a escola, a fábrica, as instituições voltadas à pobreza, o exército). O primeiro problema é a necessidade de maneiras de classificação para avaliar as pessoas e definir que tipo de regime seria mais adequado. $\mathrm{O}$ segundo concerne aos conselhos sobre como esses indivíduos poderiam ser organizados e como as tarefas poderiam ser definidas, a fim de minimizar potenciais problemas, a saber, acidentes industriais, fadiga, insubordinação, entre outros.

De acordo com Rose, a consolidação da Psicologia como disciplina científica decorreu de sua capacidade de produzir tecnologias de individualização. Uma dessas técnicas se refere à inscrição de identidades utilizando observações, registros, documentos burocráticos, Essas inscrições, quando sistematizadas, "transformam fenômenos efêmeros em formas estáveis que podem ser examinadas repetidas vezes e acumuladas no tempo" (Rose, 1998, p.108).

A primeira técnica de visualização voltou-se ao escrutínio da superfície do corpo em busca de sinais de patologias. Porém essas técnicas (que nem eram prerrogativas da Psicologia, sendo usadas na Frenologia, na Antropologia Criminal, entre outras) falharam por não proverem a diferenciação esperada das técnicas de individualização. A primeira contribuição específica da Psicologia à individualização foram os testes de inteligência - um tipo de legibilidade tornada possível pela introdução de uma nova forma de normalização proveniente da estatística: a curva normal. Por meio dos testes, a inteligência podia ser representada em forma visual, partindo do pressuposto de que todas as qualidades de uma população variavam em um padrão regular. E essa forma de visualização não ficou circunscrita à inteligência. Por exemplo, a partir da década de 1920, as crianças se tornaram objeto científico da Psicologia por meio do conceito de "desenvolvimento". Tratava-se de conceito derivado da sistematização de observações e registros que possibilitou, simultaneamente, a padronização e a normalização da infância.

As avaliações psicológicas geraram outro tipo de inscrição: o laudo. Para Rose,

Seus resultados são dirigidos à qualquer exigência institucional onde uma decisão tem que ser tomada por meio de cálculos onde figurarão as capacidades e características de um indivíduo. Acumuladas em fichas ou anotações de caso (case notes), analisadas nas conferências de casos, tribunais, ou clinicas, as inscrições de individualidade inventadas pelas ciências psicológicas são, portanto, fundamentais para os programas de governo de subjetividades e para o gerenciamento das diferenças individuais (Rose, 1998, p.112).

Entretanto, de acordo com o autor (e para outros autores que dialogam com Foucault), não se trata apenas de empreendimentos coercitivos, voltados ao controle e à repressão de subjetividades. As tecnologias discutidas por ele não funcionam exclusivamente pela repressão e nem é essa sua principal função, porém buscam produzir sujeitos de determinado tipo, moldar e organizar a psique, fabricar indivíduos com certo padrão de desejos e aspirações. São técnicas que procuram governar as diferenças individuais, com a finalidade de maximizar a eficiência individual e social. Portanto,

Como objetos de um certo tipo de regime de conhecimento, os indivíduos humanos se tornam possíveis sujeitos de um certo tipo de sistema de poder, passíveis de serem calculados, de ter coisas feitas a eles, de fazer coisas a eles mesmos em nome de capacidades psicológicas e subjetividade (Rose, 1998, p.115).

\section{A categoria sujeito na interface entre processos de objetivação e subjetivação: das contribuições de Foucault à síntese de Rom Harré}

A palavra indivíduo tende a remeter a sujeito. Mas Foucault nos adverte que, semanticamente, essas distinções não são assim tão fáceis. 
Sujeito é nomenclatura ao léu semântico, pois ora é sinônimo de assujeitamento, de ser passivo diante de processos sociais impositivos; ora é sinônimo de possibilidade de subjetivação, de ter consciência de si.

Márcio Fonseca esclarece:

Já se afirmou que tanto os processos de objetivação quanto os processos de subjetivação concorrem conjuntamente na constituição do indivíduo, sendo que os primeiros o constituem enquanto objeto dócil e útil e os segundos enquanto um sujeito. Pode-se então dizer que o termo "sujeito" serviria para designar o indivíduo preso a uma identidade que reconhece como sua, assim constituído a partir dos processos de subjetivação. Esses processos, justapostos aos processos de objetivação, explicitam por completo a identidade do indivíduo moderno: objeto dócil-eútil e sujeito (Fonseca, 2003, p.26).

Quando se fala em formas de objetivação e formas de subjetivação, é sempre em relação à constituição do sujeito. É possível, pois, dividir os textos de Foucault segundo o foco na objetivação (a constituição do indivíduo moderno como objeto, como corpo dócil e útil a partir dos mecanismos disciplinares) e sua constituição como sujeito (indivíduo preso à sua própria identidade pela consciência de si). Então, como integrar essas duas faces desse ser que somos?

É possível que a diversidade de formas de nomear quem somos não decorra apenas de nossas opções ontológicas e teóricas, como também da escolha do nível a partir do qual falamos, isto é, de nossa experiência como "eus"; das relações interpessoais com outros generalizados; enfim, de nossas vivências na interface entre processos de objetivação e processos de subjetivação. Essas distintas dimensões foram abordadas por Rom Harré (1998) em uma proposta que nos parece integradora.

Harré, como Mead, situa a pessoalidade no fluxo da ação: "a pessoa não tem outros atributos psicológicos além de seu poder de produzir o fenômeno psicológico no fluxo das ações públicas e privadas" (Harré, 1998, p.15). Em síntese, propõe que entendamos nossa experiência de singularidade por intermédio de relacionamentos interpessoais contextualizados, e não como uma interioridade ontológica. Entretanto, Harré não abandona a corporeidade e nem as materialidades que dão aos selves sua singularidade. Para ele, a pessoalidade é produto de três expressões de singularidade que denomina de self 1 , self 2 e self 3 , uma hierarquização que tem valor meramente heurístico e visa pontuar a diversidade intrínseca dos selves e a falácia de considerar a pessoalidade apenas a partir de uma das posições possíveis. Self 1, 2 e 3 são meras versões de selves que são, por definição, múltiplos. Interpretamos, portanto, que a proposta de Harré propõe o desafio de trabalhar simultaneamente com as multiplicidades de versões, decorrentes da diversidade de situações em que seres vivos e materialidades estão localizados (Law \& Mol, 2002).

O self 1 traduz a singularidade apoiando-se na experiência e na ação referidas aos nossos corpos individuais. Tem relação com a corporeidade: nossa posição no tempo e espaço, assim como nosso ponto de vista particular. O self 2 refere-se a nossas histórias pessoais, autodescrições, autoconceito e os registros de nossa presença, como os nomes com os quais somos identificados ao nascer. O self 3 concerne à apresentação pública desses selves, ou melhor, à interface entre os padrões complexos e cambiantes de disposições e habilidades que nos são atribuídas por outras pessoas, e se reporta à apresentação pública de nossos selves (Harré, 1998, p.16). Portanto, ter um sentido de pessoalidade é ter disposição para expressar-se de maneiras particulares e cada um dos selves (self 1, 2 e 3 ), por sua vez, tem seu modo característico de expressão.

Para Harré, é necessário que seja feita uma distinção entre individualidade, unicidade e singularidade. A individualidade está relacionada à dimensão temporal-espacial e decorre dos aspectos de pessoalidade que estão atrelados à corporeidade (embodiment) - ou seja, ao self 1 - e suas formas características de expressão. Difere, pois, de individualismo que, no enquadre teórico de Harré, não existe, pois nossas características pessoais, expressas no self 2 , são fundamentalmente relacionais.

A unicidade diz respeito às diferenças em todas suas propriedades, das quais algumas são genéricas, insignificantes, efêmeras, mas quase todas 
são relacionais. Este é um pressuposto central, tanto na Psicologia quanto na Medicina: cada um de nós é único.

Quanto à singularidade, cada um de nós se relaciona com o mundo (incluindo nós mesmos) a partir de um ponto de vista. Singularidade, portanto, decorre de atributos pessoais (self 2) e de pontos de vista individuais (self 1). Esses dois aspectos são imprescindíveis para a experiência de pessoalidade, mas têm estatuto diverso em diferentes correntes teóricas: segundo Harré, os autores norte-americanos tendem a privilegiar o self 2 (atributos únicos) e os ingleses, o self 1.

Com base no pressuposto relacional e nas reflexões de Harré, a noção de self concerne às maneiras de ser que se tornam organizadas na interação, de modo que é preciso trazer para discussão a capacidade de produzir relatos e comentários sobre o que percebemos, como agimos e o que lembramos; ou seja, Harré propõe uma versão de pessoa pautada na narratividade, isto é, relatos perceptuais e comentários sobre percepções, declarações de intenção e comentários a esse respeito, narrativas ordenadas sobre o passado e antecipações sobre o futuro.

Ao sugerir essa forma de olhar para a singularidade de nossos "eus", nosso propósito é duplo: de um lado, buscamos pontuar que há continuidades que escapam das intempéries de nossos relacionamentos sociais (de modo a não transformar nosso senso de singularidade em mera interpessoalidade); de outro, procuramos apontar para a complexidade dessa experiência de singularidade, situando-a não apenas na esfera da interpessoalidade, mas também na complexa matriz de materialidades e práticas sociais que, historicamente, tornaram esses processos de individualização necessários.

\section{Em suma}

Como psicólogos sociais temos de conviver com a polissemia que é própria de nossa disciplina que oferece como características a multiplicidade e a diversidade dos saberes e fazeres. Porém, podemos e devemos explicitar de onde falamos e ter o cuidado de não deixar que, inadvertidamente, diferentes tradições e gêneros de fala se mesclem em nossas práticas discursivas. Por exemplo, quais são os efeitos práticos de nos referirmos aos participantes de nossas pesquisas como sujeitos? Não os estaríamos colocando numa posição de dominados, abrindo o flanco para posturas mais autoritárias de fazer pesquisa? Ou deixando-nos enredar nas práticas burocráticas (vide o uso irrefletido dos termos de consentimento), mesmo quando pensamos estar zelando pelo bem-estar dessas pessoas e nos comportamos segundo os cânones da bioética? Se, ao proceder assim, nos justificarmos por estar usando o termo "sujeito" no sentido foucaultiano de processos de subjetivação, como escapar das ciladas linguísticas que transmutam esses sujeitos em objetos de investigação?

E quando falamos em indivíduos, não obliteramos, en passant, os processos interativos e dialógicos da produção de sentidos no cotidiano? Ou seja, ao fazê-lo, correremos dois riscos: de um lado, acataremos (mesmo que inadvertidamente) versões individualistas de teorizações sobre esse ser que somos; de outro lado, ficaremos aprisionados na clássica dicotomia entre indivíduo e sociedade.

A opção por self certamente nos situa no cerne das teorizações que buscam não dicotomizar ser e sociedade, ser e outros, materialidades e socialidades. Mas, sendo de origem anglo-saxã, ${ }^{6}$ não se traduz facilmente para as línguas latinas, pois, como dito anteriormente, o "Eu" tende a ser pensado no enquadre da singularidade e da individualidade, perdendo sua qualidade reflexiva (não há self sem outro). Acrescenta-se a essa dificuldade a estreita associação entre "Eu" e o cogito cartesiano. Há, portanto, tendência a dar ao termo conotações de individualidade e interioridade.

Caberia então usar o termo pessoa? Foi esta a proposta feita quando discutimos as bases da abordagem sobre as práticas discursivas do cotidiano. Afirmávamos, então, que a noção de pessoa era intrinsecamente relacional. "A pessoa, no jogo das relações sociais, está inserida num constante processo de negociação, desenvolvendo trocas simbólicas num

${ }^{6}$ Derivada das antigas línguas germânicas, segundo o Oxford English Dictionary. 
espaço de intersubjetividade, ou mais precisamente, de interpessoalidade." (Spink \& Medrado, 1999, p.55). Porém, acrescentaríamos agora que, para além desses jogos relacionais, a noção de pessoa - pelo menos na proposta de Harré - nos indica a necessidade de entender como as diversas tecnologias de governo, sobretudo no que diz respeito aos documentos que cristalizam identidades ( $\mathrm{RG}$, passaportes, certificados de nascimento, de batismo, de conclusão de cursos, entre muitos outros), integram a complexa matriz de práticas sociais que, historicamente, tornaram necessário teorizar sobre esse ser que somos.

\section{Referências bibliográficas}

Dumont, L. (1992) Essays on individualism: modern ideology in Anthropological perspective. Chicago, USA: University of Chicago Press.

Farr, R. (2008) As Raízes da Psicologia Social Moderna. $7^{\mathrm{a}}$ ed. Rio de Janeiro: Vozes.

Fonseca, M. A. (2003) Michel Foucault e a constituição do sujeito. São Paulo: EDUC.

Foucault, M. (2005) Em defesa da sociedade. São Paulo: Martins Fontes.

Goldman, M. (1999) Uma categoria Uma categoria do pensamento antropológico: a noção de pessoa. In: - Alguma Antropologia (pp.21-37). Rio de Janeiro: Relume Dumará.

Harré, R. (1998) The singular self. London: Sage.

Law, J. \& Mol, A. (1995) Notes on materiality and sociality. The Sociological Review, 43 (2), 274-294.

Mauss, M. (2003) Uma categoria do espírito humano: a noção de pessoa e a de "eu". In: Paulo, Cosacnaify.
Mead, G. H. (1969) Evolution becomes a general idea. In: Strauss, A. George Herbert Mead on Social Psychology (pp.3-18). Chicago, EUA: University of Chicago Press.

- (1969) The problem of society - how we become selves. In: Strauss, A. George Herbert Mead on Social Psychology (pp.19-44). Chicago, EUA: University of Chicago Press.

. (1969) Self. In: Strauss, Anselm. George Herbert Mead on Social Psychology (pp.249-284). Chicago, EUA: University of Chicago Press.

Mol, A. (1999) Políticas ontológicas. Uma palavra e algumas questões. In: Law, J. \& Hassard, J. (Eds.). Actor Network Theory and After. Balckwell Publisher. Oxford.

Rose, N. (1998) Inventing Our Selves: Psychology, Power and Personhood. Cambridge: Cambridge University Press.

(2001) Como se deve fazer a história do eu. Educação \& Realidade, 26 (1), 33-57.

Santos, B. de S. (2006). Por uma concepção intercultural dos direitos humanos. In: A Gramática do tempo: para uma nova cultura política (pp.433-470). São Paulo, Cortez.

Spink, M. J. P. \& Medrado, B. (1999) Produção de sentidos no cotidiano: uma abordagem teórico-metodológica para análise das práticas discursivas. In: Spink, M. J., (Org.). Práticas discursivas $e$ produção de sentidos no cotidiano: aproximações teóricas e metodológicas (pp.41-61). São Paulo: Cortez.

Strauss, A. (1969) George Herbert Mead on Social Psychology. Chicago, EUA: University of Chicago Press. 


\section{Das ontologias e selves: Singularidades e multiplicidades na noção de pessoa}

\section{Pedro Paulo Viana Figueiredo ${ }^{1}$}

Nossa ideia moderna de self está ligada a, ou poderíamos dizer até constituída por, um certo sentido (ou talvez uma família de sentidos) de interioridade (Taylor, 2005, p. 149).

$\mathrm{N}$

este ensaio, tenho como objetivo apontar reflexões sobre uma possível noção de pessoa articulando três desenvolvimentos teóricos: a noção de eu interiorizado de acordo com Nikolas Rose $(1997,2001)$ e Ian Hacking (2002); a ideia de performance [enactment] desenvolvida por Annemarie Mol (2008), trazendo algumas considerações sobre familiares cujas crianças sofreram violência e são atendidas em instituições como exemplo; e, por fim, a discussão de Rom Harré (1998) sobre o que seria "pessoa" no contexto da Psicologia Discursiva. Tais reflexões ajudarão a compreender como a crença de que as pessoas sejam entidades singulares implica em sociabilidades e práticas de governos do eu. De outra forma, adotar uma noção de pessoa que é construída de múltiplas formas em uma sociedade a partir do momento que diferentes ontologias constroem diferentes pessoas - faz-se, a meu ver, crucial para compreender certas práticas sociais.

\section{A noção de um eu independente: inventando e montando o self}

A relação que temos com nós mesmos atualmente é profundamente dependente e moldada a partir das "disciplinas psi". Em nossas relações cotidianas, nos expressamos em termos, linguagens e tipos de explicação

\footnotetext{
${ }^{1}$ Bolsista pela Coordenação de Aperfeiçoamento de Pessoal de Nível Superior (CAPES)
}

"adotados" dessas disciplinas: fico estressado, Lúcia está deprimida, Maurício está traumatizado. Como afirmou Gergen (1973, 1985), as disciplinas psi oferecem à sociedade repertórios que tem como intento traduzir emoções, sentimentos, ações - nossas e das outras pessoas - que modificam a forma como a sociedade explica os mais diversos fenômenos, passando a se comportar/sentir/expressar/explicar nestes novos termos oferecidos: antes Lúcia era melancólica, hoje ela está deprimida. Trauma, por exemplo, costumava significar uma ferida ou lesão física, porém, a partir de uma sequência de acontecimentos diversos na Psicologia e na Psiquiatria, o trauma psíquico passou a ocupar uma questão central na forma como o conceito de trauma aparece na constituição de eus (Hacking, 2002).

Para Hacking (2002), deveríamos estar interessados em modos possíveis de ser pessoas; modos como constituímos a nós mesmos de maneiras distintas. O autor discute então o que para ele seria uma "ontologia histórica": o modo como objetos, ou seus efeitos, que não existiam de qualquer forma reconhecível até que virassem objetos de estudo científico, passam a existir; além de estar preocupado com os conceitos gerais e organizadores e as instituições e práticas nas quais eles se materializam. E, apoiando-se em ideias de Foucault, afirma que constituímos a nós mesmos enquanto pessoas "em um local e uma época, usando materiais que têm uma organização distinta e historicamente formada" (p.3).

A própria nomeação de ontologia histórica é remetida a Foucault em seu ensaio What is Enlightment?, quando este referia que a "ontologia histórica de nós mesmos" poderia ser um estudo que se preocupasse com a " "verdade por meio da qual constituímos a nós mesmos como objetos de conhecimento', com o 'poder por meio do qual 'constituímos a nós mesmos como sujeitos que agem sobre outrem' e com a 'ética por meio da qual constituímos a nós mesmos como agentes morais"” (Hacking, 2002, p.2). Argumenta então que qualquer objeto de sua ontologia histórica se encaixa em três eixos cardeais conforme elaborados por Foucault: ética, poder e conhecimento. É a partir desses três eixos que ele discute, como exemplo, a 
história do trauma e como este torna-se um conceito organizador na constituição de eus.

Primeiro, haveria uma pessoa que se reconhece como tendo determinado comportamento e senso de self ${ }^{2}$ que é produzido por um trauma psíquico, que levou a desenvolver atualmente um grande corpo de conhecimento no campo da traumatologia - eixo do conhecimento. Em segundo lugar, no eixo do poder, há várias possibilidades:

autoempoderamento; o poder da vítima sobre os abusadores; o poder dos tribunais e dos legisladores, declarando que as regras de prescrição não se aplicam àqueles que causaram sofrimento há muito tempo, quando o sofrimento foi esquecido pela vítima; o poder dos soldados de reivindicar aposentadoria especial e outros benefícios por trauma da época de guerra. Mas, mais importante, é o poder anônimo do próprio conceito de trauma que atua em nossas vidas (Hacking, 2002, p.19).

No eixo da ética, acontecimentos distintos, atuais ou lembrados, são vivenciados como trauma: uma infância traumática pode ser usada para explicar e, por conseguinte, desculpar o comportamento antissocial posterior de uma pessoa que pode vir a ser diagnosticada como sofrendo um transtorno de personalidade qualquer. Lembranças ditas traumáticas criam um novo ser moral: "O trauma fornece não apenas um novo senso de quem os outros são, e porque algumas pessoas podem ser desta forma, mas também produz um novo senso de self, de quem se é e porque se é como é” (p.20).

Os novos modos de classificar pessoas afetam as pessoas classificadas criando, ou eliminando, possibilidades de ação. Nós mudamos em virtude de sermos classificados desta ou daquela forma; e as maneiras como mudamos em detrimento desta classificação tem um efeito de feedback sobre nossos sistemas de classificação. Ou seja, as mudanças sociais criam novas categorias de pessoa, criando novas maneiras de as

\footnotetext{
${ }^{2} \mathrm{O}$ conceito/ideia de self varia e é distinto de acordo com os diferentes autores que procuraram descrevê-lo seja como identidade, entidade interior ou vida psíquica interna. Uma reflexão interdisciplinar sobre o conceito/ideia de self nas sociedades ocidentais é feita de modo bastante interessante no livro Rewriting the Self (1997), editado por Roy Porter.
}

pessoas serem. As categorias homossexual e heterossexual, por exemplo, só passaram a existir enquanto tipos de pessoa ${ }^{3}$ a partir do fim do século XIX (Hacking, 2002). Há algum tempo ser reconhecido como nerd não é favorável: a conotação é, em sua maioria, negativa. Porém, atualmente, ser reconhecido como geek, uma variante do termo-categoria nerd, é positiva e desejável por determinado grupo de pessoas.

Esse tipo de feedback, outrora chamado por Hacking de looping effect (1995), faz com que ele denomine-se um nominalista dinâmico, opondo-se aos nominalistas clássicos que pensariam que todas as categorias, classes e taxonomias são criadas e fixadas por seres humanos e que as classificações podem ser ampliadas ou revistas, mas que quando instauradas, são praticamente fixas e não interagem com o que é classificado:

Acredito que este tipo de nominalismo estático é duplamente errado: eu acho que muitas categorias vêm da natureza, ${ }^{4}$ e não da mente humana, e acho que nossas categorias não são estáticas. Um tipo diferente de nominalismo - que eu chamo de nominalismo dinâmico - atrai meu self realista, instigado por teorias sobre feitura do homossexual e do heterossexual como tipos de pessoas ou por minhas observações sobre estatísticas oficiais. A alegação do nominalismo dinâmico não é que exista um tipo de pessoa que veio cada vez mais a ser reconhecido pelos burocratas ou pelos estudiosos da natureza humana, mas sim que um tipo de pessoa passou a existir no mesmo instante em que o próprio tipo estava sendo inventado (2002, p.106).

Ou seja, as categorias e as pessoas que são inseridas nelas emergem conjuntamente. Para o autor o nominalismo dinâmico afeta o conceito de pessoa individual, pois abre possibilidades: aquilo que somos não é apenas o que fizemos, fazemos e faremos num futuro próximo, mas também tudo

\footnotetext{
${ }^{3}$ Modos de ser uma pessoa ou condições de pessoalidade, segundo Hacking (2002).

${ }^{4}$ Esse é um argumento interessante que não tem espaço de ser tratado aqui. Peço para conferir o exemplo de Hacking sobre "cavalo, planeta, luva e personalidade múltipla" no capítulo 6 "Making Up People" do livro Historical Ontology (2002). Há uma versão deste livro em português - Ontologia Histórica (2010) - lançado pela Editora Unisinos, porém tradução e os constantes erros de grafia tornam a leitura difícil.
} 
aquilo que poderíamos ter feito e podemos vir a fazer. Inventar pessoas altera então os espaços de possibilidade de ser uma pessoa: novos modos de descrição passam a existir e novas possibilidades de ação tomam forma como consequência (Hacking, 2002).

Nikolas Rose (1997) parte de postura semelhante. Para ele, as crenças, normas e técnicas que passaram a existir sobre a alcunha das disciplinas psi através do século XX sobre inteligência, personalidade, emoções, desejos, relações grupais, distress psiquiátrico e assim por diante, não vêm de uma iluminação ou mistificação: eles mudaram profundamente os tipos de pessoas que nos são disponíveis ser - são formas de pensar a nós mesmos, modos de agir sobre nós mesmos e o tipo de pessoas que se presume que devemos ser em nossas relações de consumo, produção, vida amorosa, religiosa e modos de adoecer e morrer. Os seres humanos nas sociedades ocidentais passaram então a se compreender e relacionar consigo mesmos como

seres "psicológicos", a se interrogarem e a se narrarem em termos de uma "vida psicológica interior" que guarda os segredos de sua identidade, que eles devem descobrir e preencher e que é o padrão em relação ao qual o viver de uma vida "autêntica" deve ser julgado (Rose, 2001, p.34).

Seríamos então selves montados [assembled] nos quais os efeitos "privados" de uma interioridade psicológica são constituídos em ligação com a linguagem, prática, técnicas e artefatos “públicos”. Precisaríamos, portanto, abandonar a crença de que nós somos "por natureza" criaturas enclausuradas, habitadas e animadas por um mundo interior cujas leis e processos a Psicologia nos "revelou". Rose (2001) diz ocupar-se então com o que ele denomina, seguindo uma orientação foucaultiana, "genealogia da subjetivação". Teria por preocupação então as práticas pelas quais as pessoas são compreendidas e pelas quais se age sobre elas, tendo por domínio de investigação as práticas e técnicas sobre as quais o ser humano é pensado; tomando então esta ideia de que o ser humano enquanto individualidade interiorizada, totalizada e psicologizada como um problema histórico: "o foco não é, portanto, a história da pessoa, mas a genealogia das relações que os seres humanos têm estabelecido consigo mesmos, isto é, as práticas nas quais eles se relacionam consigo mesmos como eus" (p.35, grifos do autor).

Desta forma, o autor diz ter como intento selecionar as formas pelas quais um eu funciona como um ideal regulatório nos mais diferentes aspectos de nossas formas contemporâneas de vida, sendo montado de forma aleatória e contingente, ficando no ponto de intersecção de "uma gama de diferentes histórias, de diferentes formas de pensamento, de diferentes técnicas de regulação, de diferentes problemas de organização" (Rose, 2001, p.35), devendo estas serem tratadas a partir de uma perspectiva de governo. Ou seja, Rose afirma que nossa relação com nós mesmos tem a forma que tem atualmente porque esta tem sido o objeto de uma variedade de esquemas, mais ou menos racionalizados, que acabaram por modelar nossas formas de compreender e viver nossa existência enquanto seres humanos tendo objetivos distintos, tais como "masculinidade, feminilidade, honra, reserva, boa conduta, disciplina, distinção, eficiência, harmonia, sucesso, virtude, prazer: a lista é tão diversa e heterogênea quanto interminável” (2001, p.36).

Uma genealogia da subjetivação, portanto, concentra-se nas diferentes práticas que localizam os seres humanos em regimes de pessoa, oferecendo análises que tentam dar conta da diversidade das linguagens de "pessoalidade" que tem se formado - algumas delas listadas acima - bem como da variedade de "normas, técnicas, relações de autoridade no interior das quais essas linguagens têm circulado nas práticas legais, domésticas e industriais para atuar sobre a conduta das pessoas" (Rose, 2001, p.37).

\section{Por uma ontologia política}

A ontologia política, ou política ontológica, é um termo desenvolvido por Annemarie Mol (2008) para falar sobre as formas como o "real" está implicado no "político" e vice-versa. Uma política ontológica, portanto, refere-se à ontologia - "que na linguagem filosófica comum define o que pertence ao real, as condições de possibilidade com que vivemos" (p.63), 
ou, como afirmaria Hacking (2002), diz respeito a como os conceitos têm existências em determinados tempos históricos e às relações lógicas que foram criados entre eles e que não poderiam ser percebidas corretamente a menos que as suas dimensões temporais fossem consideradas. Portanto, a combinação destes termos, ontologia e política, sugere que as condições de possibilidade não preexistem, a realidade não precede as práticas cotidianas com as quais interagimos, e sim estão sempre sendo modeladas por essas práticas. O termo política, para a autora, permite sublinhar um modo ativo e esse processo de constante modelação, bem como o seu caráter aberto e passível de contestação.

A autora, refletindo a partir da teoria ator-rede, ${ }^{5}$ pretende retirar o caráter estável e determinado da realidade, afirmando que seria impossível não reconhecer a realidade como localizada histórica, cultural e materialmente:

Localizada onde? Depende do campo em que se responde. Nos estudos sociais da ciência, o laboratório foi redescrito como prática sociomaterial onde a realidade é transformada e onde se concebem novas formas de fazer a realidade. Estas formas são exportadas do laboratório, não tanto enquanto "teoria", mas antes, ou pelo menos na mesma medida, enquanto vacinas, microprocessadores, válvulas, motores de combustão, telefones, ratos geneticamente modificados e outros objetos - objetos que transportam com eles novas realidades, novas ontologias (p.64).

Ela deixa claro o uso do termo ontologias, querendo com isso enfatizar que se a realidade é feita e se a mesma é localizada histórica, cultural e materialmente, ela deve ser múltipla. Portanto, coexistem no presente diferentes versões, diferentes realidades e diferentes performances. Vou tentar ilustrar essas breves reflexões discutindo a partir do que é chamado de violência contra a criança e falando sobre cuidadores/as cujos filhos/as sofreram violência e são atendidos/as em instituições.

${ }^{5}$ Teoria criada por Bruno Latour, Michel Callon e John Law. Eu seria extremamente negligente em tentar explicar/resumir esta teoria em uma nota de rodapé. Porém, indico como leitura o livro Reassembling the social (2005) de Bruno Latour.
Múltiplas versões do que é considerado - ou não considerado violência contra a criança circulam na sociedade. Parafraseando Annemarie Mol, a realidade/fato apresentada como "violência contra a criança" é feita, localizada histórica, cultural e materialmente, portanto, é múltipla. Desta forma, diferentes ontologias no trato com a criança coexistem: a palmada pedagógica é defendida por alguns pais e abominada por defensores dos direitos da criança. A primeira, resumindo grosseiramente, apoia-se na ideia de que uma palmada seria um corretivo educativo, diferente do espancamento ou surra; a segunda baseia-se na ideia da criança como sujeito de direitos em que a prática da punição física é um fato hoje inaceitável, com abundâncias de estudos comprovando a maleficência a curto e longo prazo desta prática.

Da mesma forma que os defensores dos direitos das crianças apoiamse em práticas discursivas que atravessam e são atravessadas por saberes - a Medicina, o Direito e a Psicologia, por exemplo - e materialidades - leis, acordos internacionais, estatutos - que perpassam diversos níveis e estruturas institucionais, os/as cuidadores/as são atravessados tanto por saberes (e práticas) familiares, comunitários, populares, científicos e acadêmicos. Porém, suas genealogias (Foucault, 1976/2005) diferem. Tal fato possibilita inconsistências e incongruências, uma vez que cuidadores/as, ao ter contato com repertórios "corretos" no que diz respeito ao trato com a criança, conseguem conviver com estes repertórios e com outros que se implicaram/foram implicados anteriormente. A palmada torna-se distinta da surra mesmo que outros saberes legitimados afirmem o contrário e argumentem sobre o limite tênue entre as duas práticas.

Porém, desta forma estou agindo de forma perspectivista. Ou seja, estou afirmando que existe um "fenômeno lá" - a violência contra a criança - que é vista (a metáfora visual é proposital) sob diferentes perspectivas. Para os pais, nem todos os atos classificados como tal, deveriam assim o ser - a palmada, o xingamento etc. - e, para os profissionais, cada vez mais esse escopo deve ser ampliado: atualmente a violência contra a criança abrange da negligência à síndrome de Münchausen. 
Em minha pesquisa de mestrado (Figueiredo, 2010), trabalhei com a metáfora da construção, ou seja, procurei analisar como o fenômeno era construído no discurso daquelas cuidadoras sobre o que elas acreditavam ser - e não ser - violência: como se posicionavam e como argumentavam implícita e explicitamente a favor ou contra determinada práticas.

Porém, a realidade/fato "violência contra a criança” é múltipla. Como argumenta Mol (2008):

Falar da realidade como múltipla depende de outro conjunto de metáforas. Não as de perspectiva e construção, mas sim as de intervenção e performance. Estas sugerem uma realidade que é feita e performada [enacted], e não tanto observada. Em lugar de ser vista por uma diversidade de olhos, mantendo-se intocada no centro, a realidade é manipulada por meio de vários instrumentos, no curso de uma série de diferentes práticas (p.66).

Desta forma, realidades distintas sobre o trato com a criança que são performadas pelos/as cuidadores/as, no caso, pais/mães de crianças que sofreram violência e são atendidas numa instituição, são um bom exemplo. Mas, tamanho relativismo não significa que eu, enquanto pesquisador, esteja também de longe, analisando tais performances de modo a acreditar que, uma vez que eles/as descrevam e argumentem seus atos a partir de determinada posição, deva-se aceitar seus argumentos como verdadeiros e justificáveis. Pelo contrário, esse relativismo evolve questões ético-políticas (Íbãnez, 2005) no que diz respeito à violência contra a criança e acredito que diferentes argumentos que permitem a prática da violência precisam ser desnaturalizados. Portanto, faz-se importante compreender as múltiplas versões de atos que são classificados como violência contra a criança - e aqueles que não são - para estes/as cuidadores/as.

Tendo por base a discussão da noção contemporânea de eu e o que Nikolas Rose chama de genealogia da subjetivação, como discutido acima, poderia dizer que os/as cuidadores/as nestas instituições são construídos como pessoas que, por terem convivido com realidades distintas em que as práticas da violência eram naturalizadas, devem ser alvo de estratégias de governamentalidade (Foucault, 1979) que preveem a intervenção, tanto de órgãos governamentais como por órgãos não governamentais, a fỉm de adequá-los a uma normalidade. Neste caso, através da aplicação de tecnologias disciplinadoras.

Durante as intervenções com esse público - que podem acontecer por meio de palestras, oficinas, aconselhamento, orientação, visitas domiciliares etc. - as instituições utilizam diversas estratégias retóricas com os/as cuidadores/as quando há conflitos entre os novos repertórios sobre a violência que eles fornecem e o repertório dos/as cuidadores/as. É a partir desses conflitos que os/as cuidadores/as vão argumentar sobre o que eles consideram ou não violência, e os profissionais - guiados pelo discurso em sua maioria acadêmico e pautado nos direitos humanos - vão realizar argumentos sobre argumentos (Billig, 2008) para defender suas posições, bem como também podem assim fazer os/as cuidadores/as. Porém, pretendo sair deste perspectivismo em que há a "realidade lá" - a violência contra a criança - e os modos de posicionar-se sobre ela.

Adotarei então que esses/as cuidadores/as são não apenas alvos de tecnologias disciplinadoras, mas, também, pessoas produzidas por diferentes performances em sua ontologia. Pensar desta forma permite, acredito eu, entender que dispositivos de produção de sentidos - a palmada pedagógica, a surra "pra não virar gente ruim", a bolinação verbal/física "normal" da menina em puberdade entre os homens da família - produzem a experiência do ser pai/mãe e os mecanismos pedagógicos e/ou de violência aceitos/não aceitos contra seus/as filhos/as. Além disso, permite compreender também as formas que os/as cuidadores/as argumentam sobre as relações que os produziram como pais/mães que se posicionam de maneiras distintas ao performar um ato como violência ou não.

Porém, não esquecendo que, como afirma Harré (1998) “cada pessoa exercita seus poderes para apresentar um conjunto único de atitudes" (p.69). Ou seja, aqui é o self 3 , os padrões múltiplos e cambiantes de um grupo complexo de disposições, habilidades e capacidades atribuídas a nós por outras pessoas; e o self 1 , a singularidade estrutural da experiência 
individual e ação, ordenada por referência aos nossos corpos individuais que estão em jogo. Estes conceitos serão desenvolvidos logo abaixo.

\section{Pessoa \{Self 1, Self 2, Self 3\}; singular \{múltipla\}}

O modo como experienciamos o mundo e a nós mesmos como parte dele poderia ser dito como fazendo parte de uma singularidade, um único ponto de origem que nos permite estar numa coordenada espaço-temporal específica e não em outra. Enquanto digito estas linhas, meu corpo ocupa um espaço específico que não pode ser ocupado por nenhum outro neste mesmo tempo. Esta ideia de um ponto de vista em que eu percebo o mundo material ao meu redor e posso agir nele - neste momento estou digitando e até mesmo aquilo que se passa "por baixo de minha pele" poderia ser chamado de Self 1 e é indispensável para a manutenção da forma de vida humana. Ainda assim, cada ser humano é formado por uma complicada colcha de retalhos em constante mudança, de atributos pessoais disposições, capacidades, habilidades - e relações. E esta ideia de self como totalidade sempre-em-mudança de características pessoais, que poderia ser chamado de Self 2, é uma peculiaridade da atividade humana consciente. Ainda que eu tenha atributos de tipos diversos, alguns são permanentes e outros são bastante efêmeros; alguns são intrínsecos a mim e outros existem apenas em relação com outras pessoas e com o ambiente ao meu redor. Há ainda a totalidade de impressões pessoais que tentamos apresentar para outras pessoas - ser carinhoso, trabalhador, educado, por exemplo. Estes padrões múltiplos e cambiantes de um grupo complexo de disposições, habilidades e capacidades que só existem em relação e são atribuídas a nós por outras pessoas, seria o Self 3 .

O que foi conceituado nas linhas acima como selves 1, 2 e 3 é a forma que Rom Harré (1998) metaforicamente concebe uma pessoa. O autor toma como ponto de partida o fato de que, na literatura, seja ela psicológica ou não, "nem aquilo o que é chamado de pessoalidade [selfhood] nem consciência são noções claras, unívocas ou diretas" (p.1). Os seres humanos são indivíduos, mas isso não implica em possuirmos "unicidade". 6 Duas pessoas podem ter características semelhantes, mas ainda assim não são as mesmas: há a individualidade, em que somos uma coisa diferente das outras - sou Pedro e não João; e há também a unicidade, em que somos algo único e parecido com nenhuma outra coisa - sou um Pedro distinto de outro Pedro por mais que este possa parecer comigo. Para o autor (1998), isso é válido para todos os seres orgânicos:

Há uma revoada de aves, obviamente feita de indivíduos, mas para o observador humano indisciplinado não apresentam nenhuma marca individual de unicidade. Um ganso é mais ou menos intercambiável por outro. Fazendeiros, é claro, e garotas que gostam de gansos, têm um olhar diferenciado. Microbiologistas não diferenciam bactérias individuais umas das outras como seres únicos e singulares, não porque não podem fazê-lo, mas porque individualizar bactérias não tem valor imediato nenhum em seus projetos. De outra forma, no mundo humano é a unicidade, a singularidade pessoal, que é o leitmotif de todas as nossas formas de vida. (p.2)

Como dito anteriormente, ao mesmo tempo cada ser humano é uma complicada colcha de retalhos de atributos pessoais e relações sempre-emmudança. Desta forma, algo que possa ser chamado de "personalidade" é problemático, uma vez que a preservação desta unicidade no contexto de tantas similaridades entre pessoas acontece somente na relação constante com outras pessoas e com nós mesmos. Poderia ser dito que há uma unidade em cada pessoa a partir de um determinado contexto e em situações diversas, mas não algo que pode ser apreendido globalmente e rigidamente como "personalidade".

Outra forma de abordar o self seria descrevê-lo como um estado mental. Harré (1998) questiona se esta seria uma forma adequada, uma vez que lhe parece que as pessoas não possuem um "estado mental", e sim

\footnotetext{
${ }^{6}$ A palavra usada pelo autor em língua inglesa é uniqueness, que poderia ser traduzida como singularidade. Porém, pela distinção que o autor faz entre singularity e uniqueness, preferi traduzir por unicidade.
} 
produzem fluxos de ações, alguns privados, outros públicos, que apresentam uma série de propriedades que costumamos chamar de "mentais"; fluxos estes que apresentam estabilidades e repetições recorrentes. Há padrões de estabilidade, mas também de mudança, nos fluxos de atos cognitivos e emotivos que cada pessoa produz, geralmente em conjunto com outras pessoas. Os atos privados são os que mais comumente costumam ser tomados como atributos mentais. Entre os atributos de uma pessoa, não há apenas aqueles produzidos no fluxo de ação, portanto a Psicologia tem que dar cabo de explicar as habilidades e disposições necessárias para produzir o fluxo de atividades que chamamos de "vida mental" (Harré, 1998, p.3). Seu argumento é que tudo aquilo que costumamos chamar de vida mental é produzido $a d$ hoc ao decorrer das ações das pessoas, e não são nada mais que atributos de um fluxo de ação. ${ }^{7}$ Assim, não há entidades mentais: apenas ações privadas e públicas com que as pessoas se engajam.

Harré afirma então que o self, esta singularidade que cada um de nós acredita/sente ter, também não é uma entidade e sim um local de onde a pessoa percebe o mundo e um lugar no qual se pode agir. Apenas as pessoas existem: os selves seriam apenas ficções gramaticais, características necessárias de discursos orientados a pessoas. Apesar de não haver essa "entidade self", nós poderíamos tomar três aspectos (selves 1, 2 e 3) do que seria uma pessoa como modos de existência e comportamento forjados em modos de falar sobre estes aspectos utilizando pronomes, nos vários usos da expressão "o self". Desta forma, nosso senso de singularidade como seres psicológicos vem de um senso de sermos distintos, termos continuidade e sermos autônomos.

Para o autor, não haveria "camadas profundas" de fenômenos psicológicos, e sim apenas aqueles com os quais estamos familiarizados no dia a dia. Uma Psicologia científica estaria preocupada com competências,

\footnotetext{
7 Como exemplo de que a "vida mental" é produzida ad hoc, conferir Edwards e Potter (1992) e Edwards et al. (1992) para uma discussão de que nossas memórias, consideradas comumente como sendo uma entidade mental privada, são construídas retoricamente, como parte de argumentos voltados a objetivos específicos.
}

capacidades e habilidades de uma pessoa, além das suas dependências e vulnerabilidades. Algumas não irão variar nas diferentes situações com as quais nos engajamos, outras serão sensíveis ao ambiente - sendo este composto por humanos e/ou não humanos. Estaríamos ainda preocupados por padrões de similaridade e diferença naquilo que as pessoas produzem ativamente nos momentos em que suas habilidades psicológicas forem exercidas e suas vulnerabilidades atingidas. Relembrando: os produtos psicológicos da atividade humana são estruturas e existências efêmeras; elas vêm e vão num fluxo dinâmico.

Um senso de self é dependente de um "eu" como exemplar de um dispositivo linguístico de primeira pessoa do singular, em nossa gramática portuguesa. As únicas expressões referentes nos jogos de linguagem ${ }^{8}$ de autoatribuição e descrição são nomes próprios e seus equivalentes indexicais ${ }^{9}$ e não referenciais - e são usados para se referir presentemente, preteritamente ou potencialmente para pessoas corporificadas:

O senso de self como singularidade é alcançado sinteticamente, ao colocar juntos posições pessoais definidas em três distribuições [manifolds] - coisas, pessoas e eventos. Estas distribuições [manifolds] são reveladas ao atenderem à estrutura de percepção, ao padrão de comprometimentos interpessoais, expectativas e hierarquias de respeito, causa-efeito e outras sequências consecutivas dentro dos quais os eventos de uma vida são apresentados. A força indexical da primeira pessoa não é nada mais que incorporar a localidade do falante e o ato de falar nas

\footnotetext{
${ }^{8}$ A expressão “jogos de linguagem”, cunhada por Wittgenstein, salienta que a linguagem é composta de diferentes jogos em que empregamos as palavras em situações distintas com diferentes objetivos e regras. $\mathrm{O}$ usuário da linguagem desempenha um papel diferente de acordo com diferentes situações em que toma parte, tais como comandar, descrever, relatar, cantar uma cantiga, fazer uma anedota, etc. (Wittgenstein, 1953/1996, §23)

${ }^{9}$ Esta é uma expressão utilizada na Filosofia da Linguagem de Charles Peirce e também é parte importante no conceito de indexcalidade de Harold Garfinkel (1967) na Etnometodologia sendo posteriormente adotado por alguns autores da Psicologia de orientação discursiva (tais como Davies e Harré, 1990; Harré e von Langenhove, 1998; Potter, 1998; Potter e Wetherell, 1987). De uma forma geral, diz que o significado de um objeto, prática social ou conceito é dependente do contexto.
} 
distribuições [manifolds] pressupostas na percepção, ação e memória em discurso (Harré, 1998, p.17).

Então, desde que há apenas um dispositivo na gramática - "eu" - que expressa e sinaliza a localidade de uma pessoa nas três distribuições acima mencionadas, é esse o responsável por juntar diferentes localidades como fazendo parte de uma única pessoa. Sendo assim, a tese "psicolinguística" da construção social de uma pessoalidade [selfhood] é simplesmente que, ao adquirir a capacidade gramatical de usar a primeira pessoa do singular como dispositivo, as singularidades do self são trazidos à tona uma vez que eu tenho meu próprio senso de pessoa como singularidade, um ponto de vista contínuo ao longo do tempo. Eu, Pedro, nascido em Recife, cursando o doutorado em São Paulo, digitando esse texto.

Para finalizar, vamos reafirmar alguns pontos: a) nossa experiência do mundo e de nós mesmos como parte dele tem um ponto de origem, singular, que se diferencia de qualquer outro numa localidade de espaçotempo; b) nossos atributos pessoais, incluindo nossas memórias, são postas juntas num fluxo dinâmico de interações para formar um único aglomerado de histórias que é diferente dos de qualquer outra pessoa; e c) há uma unidade: as vidas, experiências, pensamentos e memórias de todas as pessoas são diferenciadas e ditas como pertencendo a pessoas distintas. Porém, não devemos esquecer que nossas vidas são complexas, estão em constante mudança e que, quando comprometidas, a própria existência do ser humano enquanto pessoa está sob ameaça (Harré, 1998, p.19).

\section{Abrindo possibilidades}

Concluirei o argumento apontando possibilidades de reflexão a partir do que foi desenvolvido até agora. As considerações de Ian Hacking (2002) e Nikolas Rose (1997, 2001), ambos tendo por base os escritos de Foucault, permitem-nos tentar compreender como regimes de pessoa distintos são desenvolvidos e criados a partir das disciplinas psi - mas, lembrando bem, não exclusivamente delas - e como isso também implica em diferentes sociabilidades. Já Annemarie Mol (2008) nos orienta a pensar como diferentes realidades são constituídas de múltiplas formas, atentando para seu caráter localizado cultural, histórico e materialmente; além de pensar a ontologia política como permitindo encará-las como um processo aberto e contestável. Rom Harré (1998), por sua vez partindo de considerações da Psicologia que tem o discurso como foco, lembra que a pessoa como singular poderia por sua vez ser dita como composta por uma multiplicidade - didaticamente chamadas por ele de selves 1, 2 e 3 - que só existe enquanto tal num fluxo dinâmico de interações e que estas exposições não dizem respeito a uma verdade última sobre a pessoa enquanto um eu interiorizado. Porém, em que isto me ajuda a compreender diferentes práticas sociais?

Acredito que responder esta pergunta propondo um método fechado de análise não ajudaria em nada, porém, utilizar estas três articulações teóricas para compreender como tipos de pessoa são criadas, nos permite alterar os espaços de possibilidade de ser uma pessoa, uma vez que ao propor novos modos de descrição estou também propondo novas possibilidades de ação. A pequena discussão feita acima sobre cuidadores/as de crianças que sofreram violência aponta um caminho no modo como utilizo esse ferramental na análise de uma determinada prática social - a violência contra a criança.

\section{Referências bibliográficas}

Billig, M. (2008) Argumentando e Pensando: uma abordagem retórica à Psicologia Social. Petrópolis: Vozes.

Davies, B. \& R. Harré (1990) Positioning: The discursive production of selves. Journal for the Theory of Social Behaviour, 20 (1), 44-63.

Edwards, D. (1992) et al. Toward a discursive psychology of remembering. The psychologist, 5, 441-445.

Edwards, D. \& Potter, J. (1992) The Chancelor's Memory: rhetoric and truth in discursive remembering. Applied Cognitive Psychology, 6, 187-225. 
Figueiredo, P. P. V. (2010) Retratos da violência contra a criança: as produções discursivas de cuidadoras que frequentam uma instituição de atendimento. Dissertação de Mestrado, Programa de Pós-Graduação em Psicologia, Universidade Federal de Pernambuco, Recife.

Foucault, M. (1979) A governamentalidade. In: poder. Rio de Janeiro: Graal.

Microfísica do

. (2005) Em Defesa da Sociedade: curso dado no Collège de France (1975-1976). São Paulo: Martins Fontes.

Garfinkel, H. (1967) Studies in Ethnomethodology. Cambridge: Polity Press.

Gergen, K. (1973) Social Psychology as History. Journal of Personality and Social Psychology, 26 (2), 309-320.

(1985) The social constructionist movement in modern psychology. American psychologist, 40 (3), 266-275.

Hacking, I. (1995) Rewriting the soul: multiple personality and the sciences of memory. Princeton: Princeton University Press.

(2002) Historical Ontology. Cambridge, Massachusetts: Harvard University Press.

Harré, R. (1998) The Singular Self: an introduction to the Psychology of Personhood. London: Sage Publications.

Harré, R. \& von Langenhove, L. (1998) Positioning Theory. Massachussets: Blackwell.

Ibãnez, T. (2005) Contra la dominación: variaciones sobre la salvaje exigencia de libertad que brota del relativismo y de las consonancias entre Castoriadis, Foucault, Rorty y Serres. Barcelona: Gedisa.

Latour, B. (2005) Reassembling the Social. An introduction to ActorNetwork-Theory. New York: Oxford University Press.
Mol, A. (2008) Política Ontológica (pp. 63-77). In: Nunes, J. A. \& Roque, R. (orgs.). Objectos Impuros. Porto: Afrontamento.

Porter, R. (ed.) (1997) Rewriting the self. Histories from Renaissance to the Present. London: Routledge

Potter, J. (1998) La representación de la realidad: Discurso, retórica y construcción social. Barcelona: Paidós.

Potter, J. \& Wetherell, M. (1987) Discourse and Social Psychology: beyond attitudes and behaviour. London: Sage.

Rose, N. (1997) Assembling the Modern Self (pp. 224-248). In: Porter, R. (ed.) Rewriting the self. Histories from Renaissance to the Present. London: Routledge.

. (2001) Como se deve fazer a história do eu. Educação \& Realidade, 26 (1), 33-58.

Taylor, C. (2005) As Fontes do Self: a constituição da identidade moderna. São Paulo: Edições Loyola.

Wittgenstein, L. (1996) Investigações Filosóficas. São Paulo: Nova Cultural. 


\section{Ideias do Teatro na formulação da ideia de Pessoa}

\section{José Estevam Salgueiro ${ }^{1}$}

Que a ação corresponda à palavra e a palavra à ação, cuidando sempre em não ultrapassar os limites da simplicidade da natureza, porque tudo o que a ela se opõe, afasta-se igualmente do próprio fim da arte dramática, cuja finalidade sempre foi e continuará sendo como que apresentar um espelho à vida; mostrar à virtude suas próprias feições, ao vício sua verdadeira imagem e a cada idade e geração sua fisionomia e características.

Shakespeare

\section{Persona e Personagem}

Z ste ensaio pretende, a partir do entendimento da origem das palavras persona e personagem, e do uso e sentido desses termos na arte cênica (teatral), contribuir para o entendimento da ideia de pessoa. O significado da palavra persona, da qual mais tarde derivará, em português a palavra pessoa, já é conhecido:

o quanto é normal, clássica, a noção de persona latina: máscara, máscara trágica, máscara ritual e máscara de ancestral. Ela aparece no início da civilização latina (Mauss, 2003, p.383).

Também, Silveira Bueno, ao discorrer sobre o verbete pessoa do Grande Dicionário Etimológico-Prosódico da Língua Portuguesa (1966), informa que:

\footnotetext{
${ }^{1}$ Bolsista pela Coordenação de Aperfeiçoamento de Pessoal de Nível Superior (CAPES).
}

Lat. Personam. A língua arcaica comprova com a sua forma persoa, tendo-se dado depois a assimilação de $R S=S S$. A princípio em Roma, persona era a máscara que os atores usavam nas cenas, justamente para tomar a individualidade da figura que encarnavam ou representavam. Por isto, ainda dizemos as personagens e também os personagens da peça, do drama, da comédia. Ensinam Battisti e Alessio que persona provém do etrusco phersu, máscara, correspondendo ao Gr. Prósopon, rosto, face, feição.

Persona é a máscara, e a palavra personagem será formada com a adição do sufixo agem, que, segundo o Dicionário Michaelis, entre diversos sentidos, traz aquele de ato, ação (do lat-aticum, pelo fr. -age). Curioso observar que o mesmo dicionário indica que o sufixo dade, que adicionado à palavra persona gera a palavra personalidade, "forma substantivos femininos abstratos que indicam características, essência, qualidade (bondade, legalidade); ideia de ação realizada, ato efetivo (barbaridade); coleção, (irmandade, mortandade)", ou seja, aparentemente quase que o mesmo significado do sufixo agem, o que poderia tornar as duas palavras, personagem e personalidade, praticamente sinônimos. No entanto, quando aplicadas em uma frase, para que a comparação dos sentidos fique evidente, por exemplo: "ele foi uma personagem da história" ou "ele foi uma personalidade da história", verifica-se que o sentido é bastante distinto de cada uma dessas palavras. Fica evidente que 'personagem' conota ação, atividade, fluxo, indeterminação, enquanto que "personalidade" conota característica intrínseca, essencialidade, fixidez.

$\mathrm{Na}$ articulação das ideias de persona e de personagem, Pavis (1999, p.285) afirma que:

No teatro grego, a persona é a máscara, o papel assumido pelo ator, ela não se refere à personagem esboçada pelo autor dramático. O ator está nitidamente separado de sua personagem, é apenas seu executante e não sua encarnação a ponto de dissociar, em sua atuação, gesto e voz. Toda a sequência da evolução do teatro ocidental será marcada pela completa inversão dessa perspectiva: a personagem vai-se identificar cada vez mais com o ator que a encarna e transmudar-se em entidade psicológica e 
moral semelhante aos outros homens, entidade essa encarregada de produzir no espectador um efeito de identificação.

Nessa passagem, pode-se perceber, por analogia, que a sobreposição entre o papel (máscara/persona) e o ator é um processo histórico longo e que culmina com o ator (pessoa) sendo identificado e reconhecido pelo papel - a personagem que executa - papel teatral, papel social, ator teatral, ator social.

Quando se aprende um papel, isto é, a execução de uma personagem, aprende-se também como será o comportamento - ação ou reação - da "plateia" e das personagens/dos papéis adjacentes, da personagem que a pessoa (ator) executa e dos outros com os quais irá interagir. Aprende-se a desenhar ações e a esperar quais serão as reações subsequentes e esperadas dos coadjuvantes e parceiros de cena. A representação parte deste pressuposto: o desempenho, estruturado e montado de acordo a regras e condições (pré)estabelecidas, compreendido, apreendido e legitimado pelo(s) outro(s), quer esse outro atue como plateia quer como coadjuvante: "Quando um indivíduo desempenha um papel, implicitamente solicita de seus observadores que levem a sério a impressão sustentada perante eles" (Goffman, 1975, p. 25).

Aqui, a presença do "jogo" - que será adiante discutida- o desempenho (ação) da pessoa/do ator se dá a partir de elementos e códigos de conduta que sejam reconhecíveis por seus pares e que criem condições de veracidade e credibilidade para esse seu desempenho:

Quando o indivíduo se apresenta diante dos outros, seu desempenho tenderá a incorporar e exemplificar os valores oficialmente reconhecidos pela sociedade e até realmente mais do que o comportamento do indivíduo como um todo. Uma representação ressalta os valores oficiais comuns da sociedade em que se processa (Goffman, 1975, p.41).

A presentificação de uma pessoa, sua representação, a apresentação/ exposição de um papel ou de uma função deve ser validada por todos os participantes da encenação/ representação/ presentificação - do ator à "plateia" - deve estar pautada nos códigos de expressão e de reconhecimento daquele grupo, tanto do ponto de vista do ator/pessoa que necessita desse código para a apreensão, estruturação e expressão dessa personagem/papel, como do ponto de visto de um segundo ator/ pessoa, singular ou plural, que atuará como interlocutor/ coadjuvante nessa encenação/ representação/ presentificação, como pela terceira posição, o ponto de vista da "plateia", que irá ler e reagir a esse desempenho, a esse papel/ personagem, a essa cena que, codificadamente, propiciará condutas adequadas e pretendidas pela encenação/ representação/ presentificação.

A tipificação das formas de ação requer haver nestas um sentido objetivo, que por sua vez exige uma objetivação linguística. Isto é, haverá um vocabulário que se refere a estas formas de ação. (...) Em princípio, portanto, uma ação e seu sentido podem ser apreendidos à parte dos desempenhos individuais dela e dos variáveis processos subjetivos que a eles se associam. O indivíduo e o outro podem ser compreendidos como executantes de ações objetivas, geralmente conhecidas, que são recorrentes e repetíveis por qualquer ator do tipo adequado (Berger e Luckmann, 1985, p.101)

No teatro, papel e personagem são sinônimos. Desta forma define-se personagem enquanto um papel estruturado, e exercemos vários papéis, coexistem em cada um de nós vários personagens. A ideia de papel, quer no teatro, quer nos contextos de interação social, traz implícita a ideia de função: fazer o papel de é fazer as funções de, é funcionar como.

Para os gregos e os romanos, o papel do ator era um rolo de madeira em torno do qual se enrolava um pergaminho contendo o texto a ser dito e as instruções de sua interpretação. Metaforicamente, o termo papel designa o conjunto do texto e da interpretação de um mesmo ator. (...) A seguir, o papel passa a ser a própria personagem. (...) Toda peça contém o que se convencionou chamar de papéis principais e papéis secundários (...) A antiga imagem do papel - partitura a ser desenrolada, trapo de pele existente antes e depois da interpretação e da qual o ator pode se separar ou desfazer-se... (Pavis, 1999, p.274-5).

Vivendo várias personagens/papéis no cotidiano, a pessoa/o ator aprende a criar e estruturar esses papéis/ personagens de forma "empírica", muitas vezes por mecanismos psicológicos de apreensão e organização da 
realidade. Outras vezes por imitação ou modelagem. Talvez se possa especular que os conhecidos métodos e técnicas teatrais sejam apenas a explicitação e sistematização de procedimentos e recursos que venham sendo usados há tempos para a constituição de reais personagens da vida.

Além disso, a relação entre persona e personagem é a relação entre o fixo, o estático e o dinâmico, em movimento. A máscara é fixa, imediatamente reconhecida por sua forma e repetição, e, quando essa máscara se movimenta e se atualiza, se presentifica diante de testemunhas, emerge a personagem. O movimento imprime tridimensionalidade à máscara. O movimento, ação, transforma a máscara em personagem. Para corroborar essa consideração, consultamos Aristóteles, em sua Poética (1450a) que, ao analisar a tragédia considera:

E como a tragédia é a imitação de uma ação e se executa mediante personagem que agem e de diversamente se apresentam, conforme o próprio caráter e o pensamento (porque é segundo essa diferenças de caráter e pensamento que nós qualificamos as ações), daí vem por consequência o serem duas as causas naturais que determinam as ações: pensamento e caráter; e, nas ações [assim determinadas], tem origem a boa e má fortuna dos homens. Ora, o mito é imitação de ações; e por "mito" entendo a composição dos atos; por "caráter", o que nos faz dizer das personagens que elas têm tal ou tal qualidade; e por "pensamento", tudo quanto digam as personagens para demonstrar o que seja ou para manifestar sua decisão (p.448).

Essa passagem deixa mais clara a dimensão ativa da personagem: ela é ação, ação vista e reconhecida pelo outro (neste caso, o espectador, aquele que vê, confirma e reconhece a personagem). A arte dramática refere-se à ação. A própria palavra drama, que gera a arte dramática (ainda que hoje traga a ideia de sofrimento e dor) originalmente significava ação, ação culminante (cf. Silveira Bueno: drama - Gr. Atos, ação): se a personagem só existe na ação e a ação ocorre em um tempo e um espaço, (como afirma Aristóteles) podemos afirmar que toda personagem é contextualizada; isto é, para se entender, e consequentemente, criar uma personagem, é necessário determinar que ação ela realiza e em que tempo/espaço (contexto) essa ação ocorre.
Explicando os dois aspectos da personagem abordados por Aristóteles e utilizando-se, para isso, dos termos gregos ethos e dianóia, Boal (1991), com sua didática peculiar, deixa ainda mais clara a questão e a relação acima apontada entre personagem e ato:

A personagem, atua e a sua atuação apresenta dois aspectos: ethos e dianóia. Juntos constituem a ação desenvolvida pela personagem. São inseparáveis. Porém, para fins didáticos, poderíamos dizer que o ethos é a própria ação e a dianóia a justificação dessa ação, o discurso. $\mathrm{O}$ ethos seria o próprio ato e a dianóia o pensamento [discursivo] que determina o ato. Convém esclarecer que o discurso é, em si mesmo, ação [ato], e que por outro lado, não pode existir ação por mais física e restrita que seja, que não suponha uma razão. Podemos igualmente definir ethos como o conjunto de faculdades, paixões e hábitos (p.48-9).

Esta passagem demonstra a coexistência de dois planos da ação: didaticamente denominadas de ação interna e ação externa. Segundo Kusnet:

ela [a ação] tem sempre e simultaneamente dois aspectos - ação interior e ação exterior, ou seja, ação mental e ação física. Essas duas formas de ação não podem existir em separado, elas se processam sempre em simultaneidade, mesmo quando uma delas aparentemente não está presente, mesmo quando uma delas aparentemente está ausente. Por exemplo, a imobilidade total de uma pessoa (ação exterior nula) simultaneamente com uma série de pensamentos frenéticos (ação interior intensa) (1992, p.23, itálicos no original).

Chekhov (1986) chama a "ação interna" de gestos psicológicos porque "o objetivo deles é influenciar, instigar, moldar e sintonizar" (p. 77) o movimento (vida) interior com a finalidade e propósito do movimento exterior,e dedica todo o capítulo 5 do seu Para o ato (1986) para abordar o conceito. Por sua clareza e poesia, vale trazer a frase de Leonardo da Vinci que Chekhov põe como epígrafe desse capítulo: "A alma deseja habitar o corpo porque sem os membros do corpo ela não pode agir nem sentir".

E Pavis (1999) chama de ação visível e invisível:

Sequência de acontecimentos cênicos essencialmente produzidos em função do comportamento das personagens, a ação é, ao 
mesmo tempo, concretamente, o conjunto dos processos de transformações visíveis em cena e no nível das personagens, o que caracteriza suas modificações psicológicas ou morais (p.2).

$\mathrm{O}$ aspecto interno da ação refere-se aos pensamentos, sentimentos, memórias, "movimentos" que ocorrem 'dentro' do ator/pessoa/personagem e não são vistos diretamente pelo público, mas de alguma forma são apreendidos por ele. $\mathrm{O}$ aspecto externo diz respeito aos dados observáveis da ação. Uma ação interna consistente e estruturada dá mais autonomia à personagem/papel, permite que ele pense, sinta e aja per si, quase que independentemente do ator. A este conjunto de fenômenos subjetivos do ator, que dão sustentação e veracidade ao personagem, é chamado também de monólogo interior ou subtexto, que de alguma maneira chega até o espectador. Esquematicamente pode-se afirmar que $a$ ação interna leva à ação externa. $\mathrm{O}$ ator/pessoa irá, por meio de procedimentos e técnicas específicas, subsidiar a criação dessa ação interior, principalmente por meio da "fé cênica", que é capacidade do ator/pessoa de acreditar, de tal forma, no seu personagem/papel, a ponto de conseguir que o público também acredite nele, no personagem. É o elemento lúdico-mágico do jogo cênico. No dizer de Kusnet (1992, p.11) "estado psicofísico que nos possibilita a aceitação espontânea de uma situação e de objetivos alheios como se fossem nosso." Eu/ator, assumo como minhas, as situações, circunstâncias e objetivos (destinos) do eu/personagem.

A personagem como ação também está presente em outra passagem na Poética de Aristóteles, (1450a -16) que, ainda em sua análise da tragédia, afirma: "o elemento mais importante é a trama dos fatos, pois a tragédia não é a imitação de homens, mas de ações e de vida, de felicidade [e infelicidade; mas a felicidade] ou a infelicidade reside na ação e a própria finalidade da vida é uma ação, não uma qualidade" (p.448).

A personagem, portanto, sempre será em relação a algo, seja outra personagem, um espaço, um objeto, um contexto, pois toda ação é ato em relação a um elemento diferente da própria ação. A ação, o ato, é aquilo que é visto, testemunhado pelo espectador e a partir da ação, do ato em relação a outro elemento que não a própria personagem - e até em algumas situações esse outro elemento pode vir a ser a própria personagem ou parte dela, - é que a qualidade é atribuída ao ator (aquele que atua, que age). A qualidade, o caráter, a característica, as qualidades, os caracteres e as características não preexistem à ação elas apenas passam a existir a partir da ação e da ação testemunhada.

A ação é o elemento principal da contradição e determina todo o resto. Trata- se da tese de ARISTOTELES: “As personagens não agem para imitar seu caráter, mas adquirem esse caráter por acréscimo, em razão de sua ação, de modo que os atos e a fábula são o fim da tragédia e é no fim que, em todas as coisas, está o principal" (1450a). Aqui, a personagem é um agente e o essencial é mostrar as diferentes fases de sua ação numa intriga bem "encadeada". É necessário ressaltar que, hoje, volta-se a essa concepção da ação como motor do drama: dramaturgos e encenadores recusam-se a partir de uma ideia preconcebida da personagem e apresentam "objetivamente" as ações, reconstituem séries de ações físicas, sem preocupação de justificá-las por um estudo psicológico de suas motivações (Pavis, 1999, p.286).

Diante de tais considerações, na análise de uma ação, de um ato, seja teatral, seja cotidiano, observa-se que:

1) Toda ação é circunscrita, ocorre em um tempo e em um espaço, que a acolhem e conotam, e a ação será "lida", sempre, em relação a esse tempo e a esse espaço que contribuem para a atribuição de sentido;

2) Toda ação tem uma logicidade que lhe é própria, tem uma estrutura: é compreensível, é possível perceber e lhe atribuir sentido, finalidade ou direção. (toda ação é comunicativa);

3) Toda ação é contínua (tem um antecedente, atos e acontecimentos que a antecedem e um depois, atos e acontecimentos que a sucedem, ou seja, toda ação acontece em uma linha do tempo);

4) Toda ação, para efeito de análise, pode ser dividida em uma dimensão 'interna', que se refere aos aspectos psicológicos, mentais, simbólicos, e uma dimensão externa, relativa aos gestos, sons e movimentos observáveis; 
5) Toda ação tem uma função própria dentro de um contexto maior da situação, do espetáculo e da cultura;

6) Toda ação, toda cena, solicita uma personagem, um código.

O passo seguinte é definir qual, ou melhor, quais são os objetivos da personagem na ação, isto é, para que ela faz o que faz, fala o que fala. Nesse sentido, é certo afirmar que os objetivos da personagem/papel não são exatamente idênticos aos objetivos da pessoa/ator, ou dito de outra forma: o ator/pessoa é diferente da personagem/papel. O ator/pessoa é, e sempre será, maior que a personagem/papel, até porque uma pessoa/ator desempenha, no seu cotidiano, ao longo de sua vida, diversas personagens/papéis:

No curso da ação há uma identificação da personalidade com o sentido objetivo das ações. A ação que está sendo executada determina, nesse momento, a autocompreensão do ator e isto no sentido objetivo que foi socialmente atribuído à ação. (...) o ator, nesse momento, apreende-se a si mesmo como essencialmente identificado com a ação socialmente objetivada (Berger e Luckmann, 1985, p.102).

Os objetivos do ator/pessoa não são os mesmos objetivos da personagem/papel - por vezes podem chegar a ser inclusive incongruentes ou até antagônicos. É claro que convivem, minimamente, ator/pessoa e personagem/papel, que esta distinção entre ator/pessoa e personagem/papel pode não ser radical, mas é fundamental que o ator/pessoa e a personagem/papel não estejam fundidos, que os objetivos do ator/pessoa não estejam fundidos e confundidos nos objetivos da personagem/papel: “(...) tanto o eu atuante quanto os outros atuantes são apreendidos não como indivíduos únicos, mas como tipos. Por definição estes tipos são intercambiáveis" (Berger e Luckmann, 1985, p.102).

Caso o ator/pessoa e a personagem/papel se misturem seria como se a máscara (persona) se aderisse de tal forma no rosto do ator que ele não mais pudesse tirá-la e, na dimensão psicológica, seria como se a pessoa/ator reduzisse todas as suas possibilidades de ser a uma única dimensão, um único papel/função, aprisionado e fixado nele.
Os objetivos de um determinado papel/função exercido podem estar bastante próximos dos objetivos da própria pessoa/ator, mas mesmo assim é possível um distanciamento, uma discriminação mínima, entre o ator/a pessoa e a personagem/o papel. $\mathrm{O}$ ator/pessoa pode conhecer os objetivos da sua personagem/do seu papel (e a recíproca, obviamente, nem procede). A pessoa/o ator domina seus papéis/suas personagens sociais da mesma forma que o ator teatral também domina suas personagens em cena. Os objetivos como ator/pessoa são maiores, mais amplos e mais diversificados do que os objetivos do personagem/papel: decorre, então, que se o ator/a pessoa e a personagem/o papel não são idênticos, e é bastante claro que não o sejam, o papel é um aspecto do pessoa, é uma fração dela - o papel é uma função.

Na concepção teatral consagrada, o que sustenta uma personagem na ação são seus objetivos: são eles que dão direção e verdade à atuação. A personagem teatral 'habita' o corpo do ator teatral que também lhe 'empresta' sua voz, seu pensamento, sua memória e até, e principalmente, suas emoções, mas a personagem teatral não é o ator, nem o ator é a personagem teatral.

Existirão papéis/personagens que estarão mais de acordo com os outros papéis que o ator/pessoa desempenha, estarão convergentes com seus valores e crenças, estarão mais próximos do conceito ou imagem que o ator faz e tem de si mesmo. A esses pode-se atribuir a condição de egossintônicos. Outros, ao contrário, mais incongruentes e distantes do que o ator conhece, imagina ou acredita sobre si mesmo, serão considerados egodistônicos. Existe ainda uma terceira possibilidade: é quando a máscara, de tão aderente e aderida, funde-se no rosto, quando o ator se mistura com o personagem ou quando a pessoa se confunde, se identifica de tal forma com o papel que acredita ser a própria personagem que representa.

A leitura das obras de Stanislavsky, já a partir de seus títulos, também irá nos informar sobre a questão da "construção da personagem", da "criação de um papel" além de indicar quais recursos comporão a "preparação do ator" para que possa dar conta dessa criação e dessa construção. Basta correr alguns itens dos índices: o estudo das 
circunstâncias externas; dar vida às circunstâncias externas; avaliação dos fatos; impulsos interiores e ação interior; o período da encarnação física; caracterização física; vestir a personagem; tornar expressivo o corpo; imaginação; concentração da atenção; unidade e objetivos; memória das emoções; adaptação; forças motivas internas; a linha contínua [da ação]; o estado interior de criação; no limiar do subconsciente

Em resumo, essas obras - A criação de um papel, A preparação do ator, A construção da personagem - indicarão como o ator, a partir de um papel escrito (um script), irá preencher esse script dando-lhe substância, consistência, historicidade, memória, passado, significação, vontade, intenção, finalidade, corporeidade e tudo o mais que for necessário para a composição do mosaico que permite imprimir vida e veracidade e um papel fixo e inerte.

\section{Pessoa, jogo e jogo cênico (dramático)}

Dentre outras articulações entre as práticas e teorias teatrais e as reflexões acerca da ideia de pessoa, está a questão do "jogo". Já vimos o aspecto lúdico no jogo de faz-de-conta ou no como se constituinte da veracidade da cena a partir da "fé cênica" exposta pelos teóricos do teatro e que pode ser transposta para a vida cotidiana, quase que diretamente. (inclusive, o faz-de-conta e o como se integram no processo de aprendizagem e constituição da subjetividade, presente nas atividades infantis).

Também partindo das considerações de Mead acerca do "jogo" e do "jogar" na constituição da pessoa, pode-se avançar e considerar que as relações das personagens - com objetos, espaço, ideias, personagens e até consigo mesma - ou entre personagem e plateia configuram situações de interações e do "jogo cênico", que envolvem e atraem a ambos os elementos da relação e trazem, revelam ou constroem sentidos.

Mead (1973) mostra que é o jogo a atividade mestra para a formação da pessoa, pois nessa atividade, o indivíduo exerce a possibilidade de se colocar no lugar do outro, a "adoção do papel do outro" (p.183); possibilidade essa advinda do regramento que caracteriza o jogo, onde cada um dos atos do indivíduo "é determinado por sua expectativa das ações dos outros que estão jogando" (p.184), e estes fatos configuram a formação da pessoa, por meio da constituição de "um outro generalizado" que permitirá a interação entre pessoas.

A comunidade ou grupo social organizado que proporciona ao indivíduo sua unidade de pessoa podem ser chamado de "o outro generalizado". A atitude do "outro generalizado" é a atitude de toda a comunidade (p.184, tradução do autor).

Aprofundando a exploração dessas ideias sobre o jogo na formação da pessoa, nosso autor continua:

Além disso, da mesma forma que adota as atitudes dos outros indivíduos para com ele e deles entre si, tem que adotar suas atitudes para as distintas fases ou aspectos da atividade social comum ou série de empreendimentos sociais nos quais, como membros de uma sociedade organizada ou grupo social, estão todos envolvidos (...) (p.184-5, tradução do autor).

O jogo, por sua natureza, permitirá a evidenciação de dois momentos no desenvolvimento da pessoa. Na primeira etapa, a pessoa individual está constituída simplesmente por uma organização das atitudes particulares de outros para com o "indivíduo" e das atitudes recíprocas nos atos específicos em que participam. Em um segundo momento, além das atitudes desses indivíduos particulares, a pessoa está composta “também por uma organização das atitudes sociais do outro generalizado, ou grupo social como um todo" (p.187).

Para melhor exploração do conceito de jogo, pode-se recorrer a Huizinga (2000), que, ainda que esteja considerando o jogo mais stricto senso, logo nas primeiras linhas de seu clássico, Homo Ludens, pondera:

mesmo sem suas formas mais simples, ao nível animal, o jogo é mais do que um fenômeno fisiológico ou um reflexo psicológico. Ultrapassa os limites da atividade puramente física ou biológica. É uma função significante, isto é, encerra um determinado sentido. No jogo existe alguma coisa "em jogo" que transcende as necessidades imediatas da vida e confere sentido à ação. Todo jogo significa alguma coisa. Não se explica nada chamando 
"instinto" ao princípio ativo que constitui a essência do jogo; chamar-lhe "espírito" ou "vontade" seria dizer demasiado. Seja qual for a maneira como o considerem, o simples fato de o jogo encerrar um sentido implica a presença de um elemento não material em sua própria essência”(p.3-4)

Nesta passagem, Huizinga deixa clara a função significante da atividade lúdica, constituinte das atividades humanas. Para esse autor, o jogo compõe a existir do homem de forma ampla e larga, estando presente em seu cotidiano de maneira muito mais forte e onipresente do que o senso comum pensa, ao atribuir o jogo apenas às crianças, às brincadeiras e aos esportes. Discutir a origem dessa tendência ao lúdico não é proposta deste ensaio, muito embora, Huizinga traga considerações sobre isso:

A psicologia e a fisiologia procuram observar, descrever e explicar o jogo nos animais, crianças e adultos. Procuram determinar a natureza e o significado do jogo, atribuindo-lhe um lugar no sistema da vida. A extrema importância deste lugar e a necessidade, ou pelo menos a utilidade da função do jogo são geralmente consideradas coisa assente, constituindo o ponto de partida de todas as investigações científicas desse gênero. Há uma extraordinária divergência entre as numerosas tentativas de definição da função biológica do jogo (idem, p.4).

Desprezando discussões sobre a origem dessa atividade, centraremos nossa atenção na sua importância e nas suas consequências, conforme também considera Huizinga. Buscar na biologia ou na natureza alguma explicação sobre o jogo não resultará em ganho para nosso entendimento sobre ele. A racionalidade também não sustenta qualquer explicação, pois "se brincamos e jogamos, e temos consciência disso, é porque somos mais do que simples seres racionais, pois o jogo é irracional", seguindo nessa direção, Huizinga propõe "tratar o problema do jogo diretamente como função da cultura", e, continua ele, "o que importa é justamente aquela qualidade, que é característica da forma de vida a que chamamos "jogo"” (idem, p.6).

Circunscrevendo sua proposta, esse autor toma o jogo como "forma específica de atividade", como "forma significante", como "função social". Sintetiza sua definição: definir jogo como uma ação livre, sentida como fictícia e situada fora da vida comum, capaz, não obstante, de absorver totalmente o jogador; uma ação despida de qualquer interesse material e de qualquer utilidade; que se realiza em um tempo e um espaço expressamente circunscritos, desenrola-se ordenadamente de acordo com determinadas regras e provoca, na vida, relações de grupos que se cercam voluntariamente de mistério ou que acentuam pelo disfarce sua estranheza diante do mundo habitual (p.16).

Tomada stricto sensu a concepção de jogo, ainda seguindo Huizinga, percebe-se que ele constitui na "manipulação de certas imagens, numa certa 'imaginação' da realidade". No entanto, tal concepção pode ser alargada e abarcar outras atividades que também serão marcadas pelo fator lúdico - a linguagem, o mito e o culto, - percebendo-se que é destes que decorrem as atividades das práticas e ordenações sociais. A percepção e análise do 'jogo de cena' presente e constituinte dessas práticas nos permitem recuperar a sua dimensão lúdica. Se entendermos algumas das características do jogo stricto sensu, fica explícita sua relação com as práticas sociais, e assim poderíamos estender sua aplicação. Recorremos, novamente a Huizinga (2000):

Reina dentro do domínio do jogo uma ordem específica absoluta. [...] Ele cria e $e ́$ ordem. Introduz na confusão da vida na imperfeição do mundo uma perfeição temporária e limitada, exige uma ordem suprema e absoluta: a menor desobediência esta 'estraga o jogo', privando-o de seu caráter próprio e de todo e qualquer valor. [...] Todo jogo tem suas regras. São elas que determinam aquilo que 'vale' dentro do mundo temporário por ele circunscrito. As regras de todos os jogos são absolutas e não permitem discussão (p.13-4)

As práticas sociais são ordenadas e circunscrevem-se em regras e expectativas nítidas e estabelecidas, tais como as regras de um jogo, em que as funções e reações estão já, minimamente previstas.

A terceira perspectiva a ser considerada é aquela trazida pela arte teatral. Das várias aplicações e acepções do termo no contexto das artes cênicas, merece destaque uma apresentada por Pavis (p.219): 
O jogo de teatro (este era antigamente o nome para o jogo de cena, aquilo que o ator faz em cena, fora do seu discurso) é a parte visível e propriamente cênica da representação. Ela obriga o espectador a receber o conjunto de acontecimentos na força de sua enunciação. Mesmo a leitura do texto dramático exige visualizar o jogo dos atores.

A ideia de "jogo" como interação ativa e articulada, quer entre personagens, ou entre personagens e "coisas" (espaço, objetos, etc.) reforça o conteúdo de atividade da personagem. É o jogo de cena que permite a apreensão e compreensão da personagem.

Tomado em seu sentido mais amplo, o jogo irá compor o próprio cerne da representação teatral: o próprio atuar é um jogar, é seguir convenções de alguma forma compartilhadas entre os atores e entre os atores e seus espectadores, e evidenciar um sentido que organiza a ação entre os atores e essa organização também captada pela plateia que participa da teatralidade. Pavis esclarece:

Para captar o jogo do ator, é preciso, na verdade, como leitor, mas também como espectador, relacionar a enunciação global (o gestual, a mímica, a entonação, as qualidades da voz, o ritmo do discurso) com o texto proferido ou a situação armada. O jogo se decompõe então em uma sequencia de signos e unidades que garantem a coerência e a interpretação do texto (p.220).

A integridade do sentido que permite a compreensão e a participação da plateia decorre do fato de ela também participar, implicitamente, do jogo proposto pela encenação, de ela ocupar um lugar que lhe é próprio nesse jogo: a plateia é um participante ativo do jogo teatral.

Explicitando ainda mais esses elementos do jogo, ultrapassando a já superada polêmica que relacionava o jogo com o falso, a simulação ou a hipócrita, ${ }^{2}$ reforçando os aspectos de convencionalidade dos jogos teatrais, Pavis afirma que:

\footnotetext{
${ }^{2} \mathrm{Cf}$. a longa discussão de Diderot a respeito no clássico $O$ paradoxo do comediante.
}

Não há jogo natural que dispense convenções e seja recebido como evidente e universal: todo jogo se baseia em um sistema codificado (mesmo que não seja experimentado enquanto tal pelo público) de comportamentos e ações que passam por verossimilhanças, realistas e teatralizados (p. 220).

Estabelecer que o "espontâneo" seja o condutor de um jogo dramático, de um jogo interacional, é estabelecer uma diretriz ideológica que impõe o que é histórico como se fosse "natural".

Para completar esta reflexão acerca da pessoa, jogo e teatro, resta trazer à tona a acepção etimológica original do termo "protagonista", que, segundo Silveira Bueno, significa "personagem principal de um drama, comédia; personagem principal, mais importante de uma tragédia, de um caso policial". Do grego protagonistès, protos, primeiro e agonistès, combatente, lutador. A ideia de "luta/oposição" já estava presente no conceito de conflito, apresentado na primeira parte deste ensaio: não importa que com um simples espaço a ser percorrido, a personagem age sobre esse espaço, vencendo-o. Na relação entre personagem e pessoa, fica agora acrescida a dimensão do protagonista: a relação entre pessoa, personagem/protagonista, aquele que luta com sua realidade.

\section{E por fim, Kusnet:}

Em conversa com um dos nossos diretores, ele me perguntou:

- E se eu lhe propusesse o papel de um simples objeto e não de um ser humano, por exemplo, o papel de uma cadeira? - você o aceitaria?

Eu respondi:

- Se essa cadeira tem amor por outra cadeira; se nutre a esperança de um dia se tornar uma poltrona. Se essa cadeira tem medo de morrer queimada num incêndio, então eu aceito o papel porque, nesse caso, a sua cadeira terá a vida do espírito humano. Do contrario, você não precisa de um ator - ponha uma cadeira verdadeira e que os seus atores falem com ela. 


\section{Referências bibliográficas}

Aristóteles. (1973) Poética. São Paulo: Abril Cultural. Col. Os Pensadores, vol IV.

Berger, P.; Luckmann, T. (1985) A Construção Social da Realidade. Petrópolis: Vozes.

Boal, A. (1991) Teatro do oprimido e outras poéticas políticas. Rio de Janeiro: Editora Civilização Brasileira.

Chekhov, M. (1986) Para o ator. São Paulo: Martins Fontes.

Ewen, F. (1991) Bertold Brecht: sua vida, sua arte, seu tempo. São Paulo: Globo.

Goffman, E. (1975) Representação do eu na vida cotidiana. Petrópolis: Vozes

Kusnet, E. (1992) Ator e método. São Paulo: HUCITEC, Rio de Janeiro: Instituto Brasileiro de Arte e Cultura.

Mead, G. H. (1973) Espíritu, persona y sociedad. Barcelona: Ediciones Paidós Ibérica.

Michaelis: moderno dicionário da língua portuguesa. (1998) São Paulo: Cia Melhoramentos.

Pavis, P. (1999)Dicionário de teatro. São Paulo: Perspectiva.

Ryngaert, J.-P. (1995) Introdução à análise do teatro. São Paulo: Martins Fontes.

Silveira Bueno, F. (1963) Grande dicionário etimológico-prosídico da língua portuguesa. São Paulo: Edição Saraiva.

Stanislavski, C. (1976) A construção da personagem. Rio de Janeiro: Civilização Brasileira.
. (1995) A preparação do ator. Rio de Janeiro: Civilização Brasileira.

(S/D) A criação de um papel. Rio de Janeiro: Civilização Brasileira. 


\section{Juventude(s), modos de subjetivação e violência: Um diálogo com aportes de Michel Foucault}

\section{Beatriz Akemi Takeiti ${ }^{1}$}

\section{Uma construção pelas bordas: introduzindo o tema juventude(s) ${ }^{2}$ e a noção de sujeito/pessoa}

$\bigcup^{\mathrm{m}}$ dos problemas que continua a desafiar as políticas de desenvolvimento social no Brasil certamente é a questão da juventude pobre $^{3}$ e o enfrentamento de questões relativas ao trabalho, à escolarização e à violência, centrais à ampliação da sua cidadania.

\footnotetext{
${ }^{1}$ Bolsista pela Coordenação de Aperfeiçoamento de Pessoal de Nível Superior (CAPES).

${ }^{2}$ Utilizamos juventude no plural para sinalizar as diversas formas de concebê-la no contemporâneo. Destaca-se aqui a diversidade que caracteriza a juventude e a importância de pensá-la histórica e socialmente inserida.

3 A pobreza, segundo órgãos oficiais como o Programa das Nações Unidas para o Desenvolvimento (PNUD, 2010) deve ser medida a partir do Índice de Desenvolvimento Humano (IDH), compreendido a partir do desenvolvimento econômico e a qualidade de vida oferecida à população. O cálculo deverá ser realizado conforme os seguintes fatores: nível educacional (anos médios de estudo), expectativa de vida da população e renda nacional bruta (PIB). Seguindo o Relatório de Desenvolvimento Humano (RDH), de 2010, o Brasil aparece, atualmente, com Índice de Pobreza Multidimensional (saúde, educação e padrão de vida) na faixa de 0,039 , semelhante patamar de países como a Turquia. Ainda, $8,5 \%$ da população vive em pobreza multidimensional, e $13,1 \%$ está em risco de entrar nessa condição. O país registra também $20,2 \%$ dos habitantes com ao menos uma grave privação em educação, $5,2 \%$ em saúde e $2,8 \%$ em padrão de vida. De acordo com os critérios internacionais de pobreza, entre os que vivem com menos de US\$ 1,25 por dia encontra-se $5,2 \%$ do total. Em relação à juventude, de um total de 1,2 bilhão de jovens no mundo, 200 milhões sobrevivem com menos de US\$1,00 per capita por dia e 88 milhões não têm emprego. Com referência aos jovens no Brasil, segundo a Pesquisa Nacional por Amostra por Domicílios (PNAD) de 2007, a população juvenil comportava 49,8 milhões de pessoas entre 15 e 29 anos, correspondendo a $29,8 \%$ da população total. Destes jovens, $29,8 \%$ poderiam ser considerados pobres porque viviam em famílias com renda familiar per capita de até meio salário mínimo. Ainda em 2007, havia 4,8 milhões de jovens desempregados, representando $60,74 \%$ do total de desempregados no país e correspondente a uma taxa de
}

Pensar a(s) juventude(s) no contemporâneo é refletir sobre que sujeito estamos falando e queremos comunicar. Requer do pesquisador um adensamento de práticas e teorias que visem a dar conta de tornar visível o invisível.

Este ensaio pretende revelar a noção de sujeito presente na pesquisa de doutorado desenvolvida pela pesquisadora, a partir das ferramentas conceituais de Michel Foucault. Como objeto-tema desta pesquisa, procuramos entender alguns vetores de subjetivação em jovens que vivenciam contextos de vulnerabilidade e de violência.

Para tanto, iniciamos a discussão buscando problematizar o binômio juventude-violência como um tensionamento atual, que produz sujeitos e modos de subjetivação. Em seguida, a partir da noção de sujeito em Foucault, apresentamos como este autor tem trabalhado com a ideia dos modos de subjetivação. Por fim, propomos pensar como a juventude, atravessada pelas máquinas sociais, dentre as quais a própria violência, tem produzido modos de subjetivação no contemporâneo.

\section{Problematizando o binômio juventude-violência}

Estudos sobre a(s) juventude(s) na interface com a violência e a vulnerabilidade têm sido desenvolvidos há trinta anos no Brasil. Apesar do crescimento e da diversidade teórico-metodológica destas produções acadêmicas, alguns estudiosos têm alertado para aspectos recorrentes e problemáticos da mesma.

Uma primeira observação é a de que frequentemente focalizam a juventude a partir do ato infracional, de programas e ações para adolescentes pobres, das condições de vida e trabalho na rua e das medidas de abrigamento (Spósito, 2009) e geralmente utilizam a "vulnerabilidade e a exclusão" como categorias autoexplicativas. (2009, p.127). Tal direção de

desemprego três vezes maior que a dos adultos. Na faixa etária entre 15 e 24 anos, as mortes violentas apontaram, em 2007, o percentual alarmante de 67,7\% (IBGE, 2008). 
investigação se, de um lado, torna visíveis processos de vulnerabilização e estigmatização de setores da juventude, de outro lado, tem reificado a associação vulnerabilidade-violência-juventude. Ao fazer da violência a marca que evidencia o juvenil, fixa-se os jovens nos territórios da exclusão e da desordem, naturalizando tal associação.

Mais do que evidenciar a violência na vida de jovens pobres, é preciso problematizá-la política, ética e esteticamente na sociedade contemporânea para que seja possível compreender como eles são forjados e forjam outras formas de invenção e criação da própria vida; como são produzidos e produzem subjetividade a partir de agenciamentos e atravessamentos que podem ser tanto da ordem singular como coletiva.

Uma segunda observação é que tais estudos pouco consideram a compreensão dos modos de vida e das experiências de violência cotidianas que atravessam as juventudes. Esta tem sido uma direção mais recente (Minayo et al., 1999; Abramovay et al., 2004; Diógenes, 2008).

Em pesquisas realizadas, principalmente na última década (Galheigo \& Takeiti, 2008; Takeiti, 2000; Takeiti, 2003), levantando a trajetória de adolescentes e jovens populares urbanos ${ }^{4}$ sobre suas condições de vida, especialmente acerca de suas atividades ocupacionais e de lazer e as oportunidades e perspectivas de futuro, nos deparamos com jovens que, se não estavam precocemente inseridos na criminalidade urbana, viviam em contextos marcados por diversas formas de violência e violação de seus direitos. Diante de tais marcas que evidenciam o social, algumas questões ainda permanecem atuais.

Como os jovens experimentam distintas formas de violência no cotidiano? Como podem viver nestes contextos, sem que tais formas configurem seu principal território de existência? Ou, como jovens pobres forjam modos de subjetivação em contextos de violência?

\footnotetext{
${ }^{4}$ Outra forma de identificar os jovens com os quais pretendemos trabalhar é esta. O leitor poderá encontrar tanto o termo "jovens pobres" quanto "jovens populares urbanos" no decorrer deste texto.
}

Nossa indagação, portanto, quer pensar os efeitos da violência, seus efeitos de produção de subjetividade e menos os fatos violentos relacionados aos jovens (Serrano, 2005). Pois, refletir a partir dos efeitos e não das causas nos leva a um posicionamento ético-político que responde a outros modos de compreensão da violência, não a ressituando em polaridades como as daqueles que a cometem ou vivenciam, mas, tendo-a como pano de fundo, compreender a constituição de sujeitos jovens. Desta forma, entendemos ser importante identificar processos - no caso, modos de subjetivação - que territorializam/reterritorializam os jovens nos circuitos da vulnerabilidade e da exclusão.

Se, por um lado, o sujeito se constitui na relação de si consigo próprio e com o outro, em processos de reciprocidade e socialização, se criando e se reinventando constante e cotidianamente, a partir dos agenciamentos que produzem efeitos de subjetivação, como explicar, pela socialização e pelos processos de interação social, explosão de violências e conflitos?

Ao adentrarmos nas esferas conceituais da constituição da noção de pessoa/sujeito, poderemos ter pistas ou hipóteses que nos permitam problematizar os modos individualizantes e essencialistas de pensar a interface juventude-violência descolados dos agenciamentos e das redes que os produzem.

Este ensaio, portanto, pretende discutir as noções de pessoa/sujeito que possam apoiar uma perspectiva ético-política de abordagem dos modos de subjetivação em adolescentes e jovens populares urbanos, de forma que tais noções desconstruam a associação violência-juventude como potencialmente perigosa e naturalmente violenta, como uma resposta simplista às maneiras de ser, viver e resistir às vulnerabilidades que atravessam projetos de vida, sonhos e desejos juvenis (Ferrandiz \& Feixa, 2005; Vicentin, 2005). 


\section{Modos de subjetivação a partir da noção de sujeito em Michel Foucault}

Subjetividade tem sido um termo bastante utilizado pelas Ciências Humanas e Sociais, particularmente pela Psicologia, para indicar a configuração psíquica do sujeito, a internalização do $e u$ a partir dos processos sociais. Em nome de uma racionalidade científica e objetiva, estabeleceram-se certos binarismos quanto à produção de conhecimento em Psicologia - individual/social, objetividade/subjetividade, corpo/mente em que conceitos como política e subjetividade conformaram territórios igualmente separados e antagônicos.

Superar estes binarismos que envolvem o conceito de subjetividade é ressituá-la ou reposicioná-la a partir de uma dimensão política compreendendoa enquanto processo produzido por intensidades e afetações, que se realiza no entre com o outro e que se constitui em "um nó de múltiplas inscrições desejantes, históricas, políticas, econômicas, simbólicas, psíquicas, sexuais" (Fernández, 2006, p. 9). Pensar na dimensão política da subjetividade e na dimensão subjetiva da política é ainda, segundo a autora, habilitar ferramentas que deem conta destas intensidades para além da produção de sentido ou da representação de determinadas problemáticas.

Dada a complexidade nos modos de compreensão do termo subjetividade cuja noção é muito ampla, será preciso apontar algumas pistas conceituais para não corrermos o risco de submetê-la a outros abismos epistemológicos. Há que problematizá-la nos seus tensionamentos, os quais são da ordem política, clínica, estética, ética.

A discussão em torno desta categoria como objeto de estudo na Psicologia ocorre a partir da década de 80, quando pesquisadores e profissionais destacam a noção indivíduo-sujeito-pessoa. ${ }^{5}$ Tal deslocamento do campo teórico-prático para a noção de subjetividade como objeto da

\footnotetext{
${ }^{5}$ Para saber mais sobre a constituição histórica do termo subjetividade no âmbito da Psicologia, ver Bernardes (2007).
}

Psicologia ocorre em virtude da crise na Psicologia decorrente da diversidade de outras orientações com distintos objetos de estudo, os quais, até o momento apresentavam-se como um obstáculo à construção de uma ciência psicológica (Bernardes, 2007).

Michel Foucault (1926-1984) é um dos autores que tem possibilitado refletir a questão trazendo aportes originais.

Foucault (2004) se insere na tradição crítica kantiana a partir da qual realiza uma história crítica do pensamento. Mas, ao se interrogar sobre os modos de subjetivação do sujeito, não o faz por meio das condições formais nem tampouco destaca as condições empíricas que, num determinado momento da história, permitiram ao sujeito tomar ciência de um objeto já dado na realidade. Foucault analisa a constituição do sujeito a partir de certo tipo de conhecimento, ou seja, dos seus modos de subjetivação em um determinado tempo e lugar.

Longe de propor neste ensaio uma tentativa de buscar um eixo de convergência nos trabalhos de Foucault em torno da subjetivação, apresentaremos algumas noções e ferramentas que se mantêm presentes na sua produção e que podem servir para balizar as formas de produção de subjetividade de jovens pobres que, cotidianamente, vivenciam e experienciam diversas formas de violência.

É sob a perspectiva da constituição do sujeito, dos modos de objetivação e subjetivação e dos processos de estetização que este ensaio procurará compreender a noção de subjetividade concebida por Foucault, não como um conjunto conceitual de fenômenos que se assemelham ou se opõem, mas como práticas que se efetuam e se atualizam constantemente em um dado momento da história.

Segundo Castro (2009), a compreensão da problemática do sujeito nas obras de Foucault percorre uma abordagem histórica da questão da subjetividade. O sujeito não existe como um a priori, dado como uma substância ou essência do ser humano como na tradição cartesiana, mas é constituído na história e na cultura. Trata-se da "história da forma-sujeito", 
sendo a forma nem sempre idêntica a si mesma (Castro, 2009). Pensar a "história da forma-sujeito" em Foucault é refletir como, em diferentes momentos da história, os seres humanos se tornaram sujeitos de uma condição política, social e cultural.

Rose (2001a), partindo das noções foucaultianas, traz a ideia de pessoa como artefato histórico e cultural. Para este autor, falar do ser humano inserido na história não é fazer uma "história da pessoa", mas "compreender as técnicas intelectuais e as práticas que têm constituído os instrumentos por meio dos quais o ser humano tem, historicamente, constituído a si próprio" (Rose, 2001a, p.35).

Rose (2001a) propõe uma genealogia da subjetivação como ferramenta do pensamento crítico, isto é, para designar como somos fabricados como sujeitos. Mais do que construir uma história da constituição de pessoa, para o autor (2001a) a genealogia da subjetivação parte das investigações sobre as práticas e as técnicas pelas quais as pessoas são compreendidas e pelas quais se age sobre ela.

Uma genealogia da subjetivação concentra-se nas práticas que localizam os seres humanos em regimes de pessoa - regimes que podem ser caracterizados como "particulares". Ela não escreve uma história contínua do eu, mas análises que tentam dar conta da diversidade das linguagens de "pessoalidade" que têm se formado (caráter, personalidade, identidade, reputação, honra, cidadão, indivíduo, normal, lunático, paciente, cliente, marido, mãe, filha) bem como da variedade de normas, técnicas e relações de autoridade no interior das quais essas linguagens têm circulado nas práticas legais, domésticas e industriais para atuar sobre a conduta das pessoas (Rose, 2001a, p.36).

A constituição dos seres humanos em regimes de pessoa em nossa cultura passa, portanto, pelos modos de subjetivação/objetivação. Assim, Foucault distingue, em seus trabalhos, três modos de objetivação que transformam os seres humanos em sujeitos. O primeiro consiste nas formas de investigação que tenta aceder ao estatuto de ciência, como um sujeito falante, pulsátil e produtivo, apresentado na gramática geral, na Filosofia e na
Linguística. Num segundo momento, Foucault se preocupa com a objetivação do sujeito naquilo que ele denominou de "práticas divisoras" ou "discordantes" que dividem o sujeito no interior de si próprio e do outro para classificá-los e fazer dele um objeto. Aqui faz uma clara separação entre o sujeito louco ou enfermo e o sujeito saudável; entre sujeito criminoso e o sujeito considerado bom. Por fim, Foucault estuda as formas pelas quais um ser humano se constitui como sujeito de si e da consciência de si, escolhendo, por exemplo, o domínio da sexualidade (Foucault, 1982/2010).

É a partir da compreensão dos modos de subjetivação e de objetivação do sujeito na história que estes momentos, anteriormente referidos, podem ser demarcados como produção de conhecimento do sujeito em Foucault.

Daí Fonseca (2007) nos alertar para a necessidade de distinguir essas duas expressões utilizadas por Foucault no conjunto de sua obra e que, por vezes, surgem como semelhantes, ora demarcam a diversidade ou, ainda, sugerem uma sobreposição. Para Foucault, os modos de subjetivação podem adquirir dois sentidos: primeiro, os modos de subjetivação constituem como modos de objetivação do sujeito, ou seja, "modos em que o sujeito aparece como objeto de uma determinada relação de conhecimento e poder" (Castro, 2009, p.408). E, num outro sentido, o autor define-os a partir da relação do sujeito consigo mesmo ou das atividades que incidem sobre si mesmo (Castro, 2009).

Segundo Veyne (2000), os modos de objetivação e subjetivação do sujeito são operados por dispositivos que constituem diversos objetos - a loucura, a carne, o sexo, as ciências físicas. Estes dispositivos fazem do "eu" de cada um o sujeito em particular ou uma pluralidade de diversos sujeitos em cada um de nós. Fonseca (2007) revela que:

[...] os processos de objetivação e de subjetivação a que Foucault se refere constituem procedimentos que concorrem conjuntamente na constituição do indivíduo. Os primeiros a fazer parte dos estudos em que Foucault se dedica a mostrar as 'práticas que dentro de nossa cultura tendem a fazer do homem 
um objeto', ou seja, os estudos que mostram como, a partir dos mecanismos disciplinares, foi possível constituir o indivíduo moderno: um objeto dócil e útil. Os segundos, por sua vez, localizam-se no âmbito dos trabalhos em que Foucault procura compreender as práticas que, também dentro da nossa cultura, fazem do homem um sujeito, ou seja, aquelas que constituem o indivíduo moderno, sendo ele um sujeito preso a uma identidade que lhe é atribuída como própria (2007, p.25).

Segundo Fonseca (2007), Foucault justapõe os processos de objetivação e os de subjetivação do indivíduo bem como as estratégias e os mecanismos que compõem este processo que, no conjunto, explicam a constituição do sujeito.

No ensaio "O Sujeito e o Poder", Foucault (1982-2010) afirma que, mais do que o poder, interessa-nos pensar como o sujeito se constitui como objeto de conhecimento na história. A ênfase dada aos estudos acerca do poder considera os processos que incidem sobre o indivíduo, sejam os modos de objetivação que produzem objetos dóceis-úteis ou pelos processos de subjetivação que tome indivíduos para que se tornem sujeitos presos a uma identidade determinada. Buscando compreender um certo tipo de sujeito, Foucault recorre aos estudos do poder, não como formas de dominação ou submissão, mas a partir das relações de forças que atravessam sujeitos, discursos, saberes e práticas.

Fonseca (2007) observa que "Foucault desenvolve a ideia de relações de forças que induzem, produzem prazeres, produzem coisas, formam saberes e produzem discursos em detrimento da noção de poder como aparelho apenas que reprime" (2007, p.34). Assim, a diversidade nas formas como o poder acontece e se atualiza aplicam-se a toda a vida cotidiana do homem, categorizando-o, marcando-o com sua individualidade, singularizando-o, como uma lei de verdade, devendo se reconhecer e sendo reconhecido nele (Foucault, 1982).

O poder faz dos indivíduos, sujeitos, seja pelo controle e dependência, seja preso à própria identidade por uma consciência ou autoconhecimento. Em ambos casos, podemos dizer que as formas de poder tornam o sujeito dependente e subjugado a determinados tipos de pessoas e objetos (Foucault, 1982). Para Fonseca (2007):

O processo dessa subjetivação se origina do poder e do saber, cria, uma vez constituída, uma dimensão da subjetividade que não depende deles. Mas, enquanto analisada do ponto de vista do processo de sua constituição, não se pode deixar de considerar as relações de poder tratadas por Foucault (2007, p.30)

Foucault (2004) afirma que o sujeito se constitui como objeto de conhecimento na relação entre os regimes de saber, de poder e de subjetividade, ou seja, a partir dos jogos de verdade estabelecidos em torno do objeto-sujeito, em que o conhecimento sobre determinado campo se dá através da construção de discursos, saberes, práticas e poderes (Foucault, 2004).

Ao estudar a arqueologia do saber, a genealogia do poder e as práticas de si é que Foucault passa a compreender o sujeito constituído histórica e culturalmente, ou seja, é a partir da constituição de saberes, discursos, ideias que o sujeito objetiva sua subjetivação. O que o autor propõe na história crítica do pensamento não é uma história das aquisições ou das ocultações da verdade, mas "a história da emergência dos jogos de verdade: é a história das 'veridicções', entendidas como as formas pelas quais se articulam, sobre um campo de coisas, discursos capazes de serem ditos verdadeiros ou falsos" (Foucault, 2004, p.235).

Foucault (2004) não realiza uma arqueologia do saber sobre qualquer tipo de verdade, mas somente a partir daqueles em que o próprio sujeito é colocado como objeto de saber possível, tentando extrair os processos de objetivação e subjetivação que fazem dele, objeto de conhecimento.

Problematizar tais processos em Foucault nos remete a pensarmos como se dá a constituição do sujeito nos regimes de verdade próprios de cada período, ou seja, como a circunscrição das regras que definem a sociedade são experienciadas por cada indivíduo, em cada época e em determinado lugar (Nardi \& Silva, 2009). É nessa inscrição histórica e cultural das práticas concretas que o sujeito é constituído na imanência de um campo de conhecimento. Pois este é atravessado pelos regimes de poder, de saber e 
pelos modos de subjetivação objetivados como processos próprios de uma experiência numa relação recíproca sujeito-objeto de conhecimento.

Se, por um lado, como já referido anteriormente, os modos de subjetivação compreendem a objetivação do sujeito em uma relação de conhecimento e poder e dele consigo mesmo, por outro lado, os processos de subjetivação também podem ser analisados à luz das formas de domínio, sujeição e assujeitamento que produzem submissão ou constituem práticas de liberdade. A esta última, Foucault denominou tecnologias do eu ou estetização.

Se a genealogia da subjetivação, como proposta por Rose (2001a), constitui aquela relação que estabelecemos com os nossos eus e ocorre a partir de uma configuração histórica, política e cultural, podemos e devemos dizer então que somos o que somos porque nos relacionamos consigo próprios e com os outros e somos governados por tecnologias criadas para moldar ou orientar nossas condutas nas direções desejadas. Para este autor,

as estratégias para a conduta da conduta operam a partir da tentativa de moldar as "tecnologias do eu", compreendidos por Foucault como os mecanismos de auto-orientação ou as formas pelas quais os indivíduos vivenciam, compreendem, julgam e conduzem a si mesmos (Foucault 1986a, 1986b, 1988 apud Rose, 2001a, p.41).

Assim, pensar numa genealogia da subjetivação (Rose, 2001b) requer a compreensão dos agenciamentos que perpassam nossa vida privada, as práticas e técnicas, os diversos dispositivos de poder, as distintas máquinas sociais, seu modo de funcionamento e engendramento que fortalecem e moldam condutas, desejos e paixões. Ainda, para este autor, a subjetivação consiste então nos efeitos de composição e recomposição de forças, práticas e relações que operam e transformam o ser humano em diferentes formas de sujeito, "em agenciamentos heterogêneos de corpos, vocabulários, julgamentos, técnicas, inscrições [...] em seres capazes de tomar a si próprios como os sujeitos de suas próprias práticas e das práticas de outros sobre eles" (Rose, 2001b, p.143).
Retomando a ideia das tecnologias do eu ou de estetização, é a partir de 1982, quando Foucault profere o curso "A hermenêutica do sujeito" no Collège de France, que passa a privilegiar o tema das práticas de si, das técnicas de subjetivação, do vínculo histórico da subjetividade à verdade. Faz uma ressignificação do sujeito denunciado durante toda a sua trajetória filosófica. Ressalta que o sujeito das técnicas de si, das artes da existência é um eu ético, mais do que um sujeito ideal de conhecimento (Gros, 2008).

Gros (2008) afirma que o sujeito, nesse momento para Foucault, deve ser "compreendido como transformável, modificável: é um sujeito que se constrói, que se dá regras de existência e conduta, que se forma através dos exercícios, das práticas, das técnicas, etc.” (2008, p.128). Mais do que entender o si das práticas do sujeito, Foucault assinala a necessidade de compreender a "relação consigo". Para ele, a subjetividade não constitui uma substância ou uma determinação transcendental, mas uma questão prática, na qual o sujeito se relaciona consigo próprio para se construir, se elaborar como sujeito de si (Gros, 2008). Foucault marca uma clara distinção na constituição do sujeito moderno nesse momento, pois, no projeto anterior, sua preocupação se dirigia aos modos de subjetivação que estavam atrelados aos regimes de verdade, saber e poder.

Segundo Veyne (2000), produção de subjetividade em Foucault poderia ser compreendida a partir da ideia de estetização como produto e processo de acontecimentos, fatos, situações ou vivências que se singularizam, referindose "a transformação de si por si mesmo" (Veyne, 2000, p.65).

A estetização constitui-se um modo de ser próprio cujo produto é a liberdade. Esta noção não é uma conformação imposta por dispositivos ou objetivações do social, mas representam processos de subjetivação livres, modos de criação e eleições individuais que não se impõem por elas mesmas, mas por vontades próprias, singulares (Veyne, 2000).

A construção de uma arte de viver está associada à ampliação do grau de liberdade com que se vive a vida, assim como a produção de estratégias para que se possa estabelecer uma maior reciprocidade e alternância de posicionamento nos jogos de poder 
e verdade. Esse é um movimento intrínseco de resistência às formas de dominação, uma vez que evita que as mesmas se tornem rígidas a ponto de bloquear a liberdade transformando-se em "estados de dominação" (Nardi \& Silva, 2009, p.144).

Para Nardi e Silva (2009), o conceito de estética em Foucault não está atrelado ao culto à beleza ou ao gozo pela vida, mas à capacidade do homem em deixar-se afetar sensivelmente pelo outro e pelo mundo. Este é o elemento que compõe as práticas de estetização como um modo de reflexão da liberdade. Para estes autores, o desenvolvimento de uma estética da existência foucaultiana consiste na possibilidade de as pessoas poderem gozar livremente de suas liberdades, atualizando os processos de subjetivação ao construir a própria experiência.

É, portanto, a partir da experiência estética da subjetivação, em Foucault, que pretendemos pensar como jovens, que vivenciam cotidianamente processos de vulnerabilidade e violência, produzem subjetividades livres, inventando novos modos de ser e viver no mundo.

\section{Considerações finais}

Que sujeitos jovens se constituem na contemporaneidade que não aqueles ditados pelos manuais de Psicologia como naturalizados, essencializados, normalizados e disciplinados? Como a juventude, particularmente aquela que habita espaços de vulnerabilidade e violências, deve ser pensada?

Quais subjetividades vêm sendo produzidas hegemonicamente como técnicas de governo, de tutela sobre suas vidas [dos jovens]? Quais têm sido construídas para determinados segmentos, como os marginais, os desqualificados e os inferiores? Ao compreender e problematizar as forças que nos atravessam e nos constituem enquanto pessoas, como é possível pensar a gestão das vidas, particularmente, a de jovens? (Nascimento \& Coimbra, 2010, p.42)
A resposta para tais indagações poderia ser efetuada pela via da resistência ao produzir "modos éticos e criativos de estar no mundo" como afirmam Nascimento e Coimbra (2010, p.47).

É preciso entender a resistência juvenil não como um modo de luta contra os poderes dominantes ou a determinadas maneiras de normalização vigentes, mas segundo "outra forma de (re)existir, como afirmação de processos inéditos de vida” (Nascimento \& Coimbra, 2010, p.48).

Uma chave de leitura para a compreensão da juventude e seus modos de subjetivação em meio à violência é desnaturalizar a carga ideológica que a constitui. É necessário desmistificar tal carga que reveste de sentido comum os jovens e a violência, reificando-os como fruto de processos históricos e sociais. Feixa e Ferrándiz (2005, p.12), revelam que "desnaturalizar a violência juvenil supõe (re)politizar (ressituar nas lutas pelo poder) a violência exercida e padecida pelos jovens e (a)culturar (ressituar nas lutas pelo significado) os códigos compartilhados que a inspiram".

Há necessidade de se considerar a juventude e seus modos de ser e estar no mundo não por meio de ações fragmentadas que fogem aos padrões tidos como organizados ou como condutas impulsivas, antissociais e até perigosas, mas como modos de objetivar subjetivações singulares e coletivas por outra via, talvez pela forma da estetização (Veyne, 2000).

A juventude, ao ser concebida e compreendida esteticamente, cria e inventa outras práticas de vida, resistindo às padronizações, modelizações, patologizações e criminalizações, escapando à lógica do capital. Nascimento e Coimbra (2010) esclarecem que:

Alguns movimentos de resistência dos jovens produzem, de maneira indubitável, revoluções moleculares, ou seja, forjam mudanças micropolíticas em seus atores e nos cenários onde atuam, afirmam e apontam para novos caminhos e invenções. Em outras palavras, diferentes experiências empreendidas pela juventude em seu cotidiano configuram práticas de resistência, expressas por meio da música e de outras artes, de micro-organizações coletivas e 
de redes de solidariedade que escapam aos simples assistencialismo tão em voga no mundo contemporâneo (2010, p.48).

Tomando os movimentos de resistência juvenil como produção de subjetividades, como verdadeiras revoluções moleculares, alguns jovens apontam caminhos para driblar as condições sociais em que se encontram. Movimentos juvenis que surgiram ao redor do mundo - anarco-punks, hippies, funks, movimento hip hop - buscam espaços de identificação questionando um estilo plástico, de massiva reprodução e "modelização" da própria subjetividade na contemporaneidade (Arce, 1999).

São dos encontros da "galera" e das irrupções das expressões culturais juvenis que é preciso pensar alternativas de resistência, modos de se criar e se (re)inventar, quais sejam, romper com o que já existe, afirmar outras lógicas, produzir novas realidades.

Estas reflexões constituem o fio condutor que alimenta ideias, noções e problematizações acerca da produção dos modos de subjetivação em jovens populares urbanos os quais, diante de contextos marcados pela violência, desigualdades e vulnerabilidades, criam ou inventam outras formas de viver, resistindo às invisibilidades do cotidiano.

As leituras e discussões realizadas neste ensaio, a partir da noção de sujeito empreendida por Michel Foucault, nos oferecem pistas para a construção de reflexões e outros entendimentos a fim de se elaborar a noção do sujeito-jovem que se deseja afirmar na contemporaneidade.

\section{Referências bibliográficas}

Abramovay, M. (et. al.) (2004). Gangues, galeras, chegados e rappers: juventude, violência e cidadania nas cidades da periferia de Brasília. Rio de Janeiro: Garamond.

Arce, J. M. V. (1999). Vida de barro duro: cultura popular juvenil e grafite. Rio de Janeiro: Editora UFRJ.
Bernardes, L. H. G. (2007). Subjetividade: um objeto para uma psicologia comprometida com o social. São Paulo: Casa do Psicólogo.

Brasil (2001/2002). Pesquisa Nacional por Amostra de Domicílio, $P N A D / I B G E$. Rio de Janeiro. Acessado em Fevereiro de 2009, site: www.ibge.gov.br

Castro, E. (2009). Vocabulário em Foucault: Um percurso pelos seus temas, conceitos e autores. Belo Horizonte: Autêntica Editora.

Diógenes, G. (2008). Cartografias da Cultura e da Violência: gangues, galeras e o movimento hip hop. $2^{\mathrm{a}}$ Ed. São Paulo: AnnaBlume.

Galheigo, S. M. \&Takeiti, B. T. (2008). A Violência no Cotidiano: o que os imaginários e as vivências dos jovens têm a nos dizer? Anais do XX Congresso Brasileiro de Saúde Coletiva, ABRASCO, Salvador, BA

Feixa, F. \& Ferrándiz, C. (2005). Jóvenes sin tregua: Culturas u políticas de la violencia. Espanha: Antropos Editorial.

Fernández, A. M. (2006). Prólogo. In: Fernández, A. M. Política y Subjetividad: asambleas barriales y fabricas recuperadas. $1^{\mathrm{a}}$ Edição. Buenos Aires: Tinta Limón.

Fonseca, M. A. (2007). Michel Foucault e a Constituição do Sujeito. São Paulo: EDUC.

Foucault, M. (1982). O Sujeito e o Poder, In: Dreyfus, H. L. \& Rabinow, P. Michel Foucault, uma Trajetória filosófica: para além do estruturalismo e da hermenêutica. Rio de Janeiro: Forense Universitária.

. (2004). Ditos e Escritos, IV - Estratégia, Poder-Saber. Rio de Janeiro: Forense Universitária.

Minayo, M. C. de S. (et. al.) (1999). Fala Galera: Juventude, Violência e Cidadania na Cidade do Rio de Janeiro. Rio de Janeiro: Garamond. 
Nascimento, M. L. do \&Coimbra, C. M. B. (2010). Juventude Normatizada, Moralizada e Violentada: alguns modos de subjetivação contemporâneos, In: Boucayuva, H. \&Nunes, S. A. (org.) Juventudes, Subjetivações e Violências. Rio de Janeiro: Contra Capa.

Revel, J. (2005). Foucault: Conceitos essenciais. São Carlos: Claraluz.

Rose, N. (2001a). Como se deve fazer a história do eu? Revista Educação \& Realidade, 26 (1), 33-57.

Rose, N. (2001b). Inventando nossos eus. In: Silva, T. T. da. Nunca fomos humanos: nos rastros do sujeito. Belo Horizonte: Autêntica.

Serrano, J. F. (2005). La cotidianidad del exceso: Representaciones de la violencia entre jóvenes colombianos, In: Feixa, F. \&Ferrándiz, C. Jóvenes sin tregua: Culturas u políticas de la violencia. Espanha: Antropos Editorial.

Spósito, M. P. (2009). O estado da arte sobre juventude na pós-graduação brasileira: Educação, Ciências Sociais e Serviço Social (19992006). Belo Horizonte: Argumentum

Takeiti, B. A. (2000). O Contar e o Repensar a própria história - uma metodologia de investigação e intervenção. Monografia. Pontifícia Universidade Católica de Campinas.

Takeiti, B. A. (2003). O Adolescente e a Violência - uma análise da configuração de sentidos do adolescente sobre o fenômeno da violência. Dissertação de Mestrado. Programa Pós-Graduado em Psicologia Social. Pontifícia Universidade Católica de São Paulo.

Veyne, P. (2000). El Infrecuentable Michel Foucault: Renovacion del pensamiento crítico. Espanha: Letra Viva.

Vicentin, M. C. G. (2005). A Vida em Rebelião: jovens em conflito com a lei. São Paulo: HUCITEC.

\section{Relações conjugais violentas: Processos de subjetivação e suas várias dobras}

Jullyane Brasilino ${ }^{1}$

Presente texto se propõe a discutir a noção de pessoa que orienta nossa pesquisa de doutorado que tem por objetivo investigar o impacto psicossocial da judicialização ${ }^{2}$ nas relações de pessoas envolvidas em denúncias de violência conjugal, cujos processos estão sendo julgados no Juizado de Violência Doméstica e Familiar Contra a Mulher, instituído pela Lei 11.340/06 (conhecida como Lei Maria da Penha).

Nossa exposição se dará em torno de três eixos, a saber: 1) a judicialização das relações conjugais; 2) a noção de pessoa presente em nossa discussão e 3) os processos de subjetivação entendidos como dobras.

\section{A judicialização das relações conjugais}

Esse eixo da discussão versa sobre a judicialização das relações conjugais e suas implicações nos modos de ser das pessoas na contemporaneidade. Para isso se faz necessário um resgate do cenário da violência conjugal.

No Brasil, hoje em dia, as mulheres em situação de violência doméstica e familiar podem contar com aparatos jurídico-legais para se protegerem e são, até certo ponto, estimuladas a fazerem denúncias e

\footnotetext{
${ }^{1}$ Bolsista pelo Conselho Nacional de Desenvolvimento Científico e Tecnológico (CNPq).

${ }^{2}$ Entendemos judicialização como uma forma de governo/controle sobre a vida das pessoas a partir de dispositivos legais, jurídicos.
} 
levarem seus casos (inscritos sob a nomeação de "violência doméstica e familiar") ${ }^{3}$ para a justiça.

A partir da instituição da Lei Maria da Penha, a violência doméstica e familiar contra a mulher passou a ser definida como um crime com procedimento particular, o que gerou amplo interesse no debate público e uma transformação simbólica do conceito de violência contra a mulher deixando de ser considerada crime de menor potencial ofensivo. Do mesmo modo, alterou do ponto de vista prático o cotidiano das instituições que atuam no enfrentamento da violência contra a mulher, a partir da criação, dentre outras conquistas, dos Juizados de Violência Doméstica e Familiar Contra a Mulher. Esses Juizados constituem um grande avanço, na medida em que possuem competência cível e criminal, pondo fim a ações fragmentadas entre o direito penal e o cível que muitas vezes tornavam morosos os processos.

A Lei 11.340/06, em especial, foi implantada para criar "mecanismos para coibir a violência doméstica e familiar contra a mulher", com destaque para "a criação dos Juizados de Violência Doméstica e Familiar Contra a Mulher". A partir de propostas de prevenção (para a sociedade), assistência (para mulheres) e responsabilização (para os homens), esta lei propiciou a reconfiguração da violência, antes circunscrita e legislada dentro de casa ou a partir de dispositivos jurídicos que a inscreviam entre aquelas de menor potencial ofensivo (Medrado \& Méllo, 2008).

Os processos jurídicos no contexto da violência contra a mulher, de modo geral, passaram a penetrar o espaço privado do casal, tornando pública (em audiências e documentos) a vida pregressa do acusado e da denunciante. E, como destaca Rifiotis (2004), o espaço da audiência abre a possibilidade de avaliação, por um terceiro, dos atos de ambas as partes, a fim de extrair as razões que os condenam ou absolvem: "Assim, os dilemas entre a moralidade pública e a moralidade privada são explorados para a construção da verdade jurídica" (p.110). Tal processo toma configurações

\footnotetext{
${ }^{3}$ Art. $1^{\circ}$ Esta Lei cria mecanismos para coibir e prevenir a violência doméstica e familiar contra a mulher.
}

ainda mais complexas quando estamos falando em eventos culturalmente considerados da vida privada, como a violência doméstica e familiar.

A Lei Maria da Penha e seus instrumentos de aplicação podem ser entendidos como uma tecnologia de governo de si e dos outros (Foucault, 1994/1982), que opera e interfere na constituição das pessoas. Além de prever as penalidades do código penal para o homem que a cometer, essa lei trouxe várias contribuições como, por exemplo, a determinação de medidas protetivas de urgência para as mulheres em situação de risco de morte. Contudo, a judicialização das relações sociais (conjugais) não dá conta do problema da violência conjugal.

O termo "judicialização" foi utilizado por Rifiotis (2004) a partir de pesquisas realizadas em delegacias de atendimento especializado às mulheres em situação de violência. $\mathrm{O}$ autor parece criticar os movimentos sociais em sua luta pela penalização da violência de gênero, destacando, a partir de uma leitura de inspiração foucaultiana, que a vida das populações está cada vez mais submetida ao jugo dos mecanismos de governo de base jurídica, fundamentados na expansão do olhar e da força política de gestão, controle e normatização da vida conquistada pelo Direito. A expansão jurídica de normatização da vida acaba por gerar outros processos de violência, o que, possivelmente, não responde à demanda por transformação existente nos discursos daqueles que a defendem.

A discussão acerca da judicialização ainda é bastante recente e controversa. É preciso trabalharmos para a punição dos atos criminais, entretanto, isso não é suficiente. A prisão como medida social impõe limites. Além do mais, fazem-se necessárias políticas sociais mais amplas, que atuem diretamente nos conflitos, além de serviços que ampliem o acesso a outros modos de resolução de conflitos e seu agenciamento e possibilidades de negociações. A atenção não deve estar totalmente focada no campo do Direito. São necessárias políticas públicas de educação, trabalho, lazer, cultura etc. que respondam às demandas de transformação. Já que os assuntos que estão sendo aqui tratados são a violência conjugal, os valores e comportamentos cotidianos, não devemos fazer apelo apenas à ordem jurídica. 
O governo da vida exercido pela Lei estabelece novos regimes de verdade sobre a violência conjugal, talvez a forma de violência mais afetada pelo processo de legitimação pública dessa lei, visto que regula relações consideradas de âmbito privado. A judicialização pode ser entendida como uma forma de interpretar a violência conjugal a partir de uma leitura estigmatizante. A consideração da polaridade vítima/agressor e/ou vítima/réu, denunciado, acusado, seria uma forma de enxergar a violência conjugal que impõe uma série de limites à sua compreensão e às suas possibilidades de intervenção.

Homens e mulheres, acusados e denunciantes, têm responsabilidade pela qualidade e continuidade (ou não) das suas relações. O resultado do enfoque na judicialização desencadeia uma reflexão cuja leitura deixa de ser focada na violência para focar o Direito. Nesse sentido, a judicialização das relações conjugais configura-se como um conjunto de práticas e de valores pressupostos, que lê a violência conjugal de uma forma criminalizante e estigmatizadora. Além disso, tal leitura tem a base na polaridade vítima/agressor e na figura do réu, com vista à criação de mecanismos jurídicos para ampliar o acesso ao sistema da justiça para problemas antes considerados de ordem privada, a fim de reduzir a impunidade (Rifiotis, 2007).

\section{Sobre a noção de pessoa}

As considerações anteriormente traçadas acerca da judicialização já denunciaram que esta interfere nos modos de ser das pessoas. Nosso próximo desafio é deixar claro de quem estamos falando, ou seja, qual a noção de pessoa (pessoalidade) presente em nossa pesquisa. Méllo, Medrado e Bernardes, (2010) apresentam uma discussão sobre a Lei Maria da Penha, entendendo-a como uma tecnologia de governo ou de gestão da vida que resulta em modos de ser. O sistema jurídico, suas materialidades e sociabilidades inscrevem e estão inseridos em jogos de poder.
Consideramos, portanto, que o conhecimento das leis, em seus contextos de produção e implantação no meio judiciário, pode ajudar na compreensão dos elementos normativos e prescritivos que contribuem para a definição, manutenção e até mesmo para a mudança das relações sociais e de processos de subjetivação, o que possibilita a configuração de novas/ outras pessoas e práticas sociais. Isso nos leva a problematizar a noção de pessoa que entendemos estar presente (e constituindo) os processos de subjetivação de pessoas envolvidas em relações conjugais violentas.

Para demarcar qual a noção de pessoa que atravessa nosso objeto de estudo nos baseamos em Rose (2001a). Partindo da proposta de fazer uma história do eu, o autor afirma que tal propósito é uma genealogia da relação do ser consigo mesmo, além das possibilidades que tal relação tem assumido. Nesse sentido, o foco não é na história das pessoas e sim nas relações que ele chama de "genealogia das relações" que o ser humano tem estabelecido consigo, com seus eus. ${ }^{4}$ Essa forma de nos relacionarmos com nós mesmos está para além das mudanças históricas e culturais nas quais estamos imersos. Devem ser tratadas da perspectiva do governo que molda a forma como compreendemos e vivemos nossas existências como seres humanos “[...] em nome de certos objetivos - masculinidade, feminilidade, honra, reserva, boa conduta, civilidade, disciplina [...]" (p.36). O que ele chama de subjetivação é o que nos acompanha ao longo de nossas vidas, um processo interminável.

O processo de subjetivação consiste das práticas e processos heterogêneos que permitem aos seres humanos que se relacionem consigo mesmos e com os outros sujeitos. A história da subjetivação é composta das práticas e técnicas que localizam os seres humanos em regimes de pessoa. Tais regimes são particulares e sua análise precisa dar conta da diversidade de linguagens possíveis. A pessoa é entendida como o alvo de uma multiplicidade que não pode ser capturada ou diagnosticada pela ciência psi, por exemplo.

\footnotetext{
${ }^{4}$ Aqui usamos "eu" por ser o termo adotado pelo autor, contudo, ressaltamos que tal expressão limita várias possibilidades. Em maior conformidade com nosso posicionamento seria o uso do termo "self", que infelizmente não tem tradução direta para o português.
} 
Os efeitos da composição e recomposição das forças que operam sobre e transformam os seres humanos são assim nomeadas por Rose (2001b) como processos de subjetivação.

Uma forma melhor de ver os sujeitos é como "agenciamentos" que metamorfoseiam ou mudam suas propriedades à medida que expandem suas conexões: eles não "são" nada mais e nada menos que as cambiantes conexões com as quais eles são associados (p.146).

Tal forma de entender as pessoas e os processos de subjetivação que as possibilita múltiplas formas de ser no mundo nos indica caminhos de análise das relações conjugais violentas.

\section{Processos de subjetivações como dobras}

Uma vez tendo apresentada a pessoa de quem falamos, passaremos ao último eixo da discussão, que trata dos processos de subjetivação, entendendo-os como dobras (deleuzianas).

O termo subjetivação é polissêmico e ao usá-lo é mister sinalizarmos a partir de quais autores estamos balizando as discussões ora trazidas. Destacamos a noção desenvolvida por Rose (2001b) a partir das ideias de Foucault e Deleuze.

O termo "dobras deleuzianas" foi uma proposta do autor de tratar da subjetivação como um processo que constitui um dentro que é a dobra de um fora, assim, não existe uma exterioridade absoluta nem uma interioridade unificada. As regiões do ser passam por dobras.

Pensar subjetivação como dobras significa pensar em termos dos efeitos da composição de forças, práticas e relações que operam para transformar o ser humano em variadas formas de sujeito, em seres capazes de tomar a si próprios como os sujeitos de suas próprias práticas, sem abandonar a dimensão dos coletivos sociotécnicos - implicados nos fluxos que se dobram - e de sua historicidade, atualizada nas práticas e instituições (Oliveira, 2005, p.59).
De acordo com Revel (2005), a postura foucaultiana é de que os modos de subjetivação do ser humano correspondem à análise dos modos de objetificação que torna os seres humanos sujeitos e o modo pelo qual a relação consigo, por intermédio de certo número de técnicas, permite constituir-se como sujeitos de sua própria existência. Desse modo, a subjetividade é o modo pelo qual o sujeito faz a experiência de si, num jogo de verdade no qual se relaciona consigo mesmo. Trata-se de uma subjetividade em movimento, em desprendimento consigo mesma, ao mesmo tempo em que é produto das determinações históricas do trabalho sobre si.

Já Guattari (2008/1992), usa o termo pessoa e destaca que o importante é a constituição de complexos de subjetivação

[...] indivíduo-grupo-máquina-trocas múltiplas que oferecem à pessoa possibilidades diversificadas de recompor uma corporeidade existencial, de sair de seus impasses repetitivos e, de alguma forma, de se ressingularizar (p.17).

$\mathrm{O}$ autor destaca que a subjetividade é fabricada também nas grandes máquinas sociais mass-mediáticas e linguísticas. Trata-se de uma subjetividade parcial, pré-pessoal, polifônica, coletiva e maquínica, ou seja, está sempre em construção.

Proporemos então operar um descentramento da questão do sujeito para a da subjetividade. O sujeito, tradicionalmente, foi concebido como essência última da individuação, como pura apreensão préreflexiva, vazia, do mundo, como foco da sensibilidade, da expressividade, unificador de estados de consciência. Com a subjetividade, será dada, antes, ênfase à instância fundadora da intencionalidade (Guattari, 2008/1992, p.35).

Embora tenha utilizado várias ideias foucaultianas na construção de seus argumentos sobre subjetivação, de acordo com Rose (2001b), Guattari e Deleuze foram os autores que propuseram a alternativa mais radical em oposição à imagem convencional da subjetividade como coerente, durável e individualizada, uma vez que os humanos são mais múltiplos e transientes do que podemos imaginar. Rose traz esses dois autores como uma plataforma de lançamento de suas indagações: "como os humanos são 
subjetivados, em quais agenciamentos, e como podemos pensar as práticas psi como um elemento operativo no seu interior" (p.143).

As tecnologias da subjetivação são maquínicas, operações pelas quais nos reunimos em montagens com elementos intelectuais e práticos, componentes, entidades e aparatos que produzem formas de "serhumano", localizadas e possibilitando relações que os humanos podem estabelecer consigo.

Tais tecnologias operam por intermédio do agenciamento em uma variedade de locais, e de uma relação consigo mesmo, por um constante autoexame, avaliações das experiências pessoais, "emoções e sentimentos em relação a imagens psicológicas de realização e autonomia" (Rose, 2001b, p.194).

O eu (self) não deveria ser estudado como um espaço delimitado de individualidade humana, circunscrito pelos contornos da pele. Nossos corpos não terminam na pele, são resultantes de uma história e de suas inúmeras invenções. $\mathrm{O}$ autor sugere que todos os efeitos da "interioridade psicológica" e das demais capacidades e relações são efeitos da ligação entre humanos e demais objetos, práticas e forças. As pessoas funcionam como uma forma heterogênea de acordo com suas inserções no mundo.

Não se trata, portanto, de um eu que emerge por meio da narração de histórias, mas, antes, de examinar o agenciamento de sujeitos: de sujeitos combatentes em máquinas de guerra, de sujeitos laborais em máquinas de trabalho, de sujeitos desejantes em máquinas de paixão, de sujeitos responsáveis nas variadas máquinas de moralidade (Rose, 2001b, p.166).

Essa forma de entender a subjetivação não a situa como um produto da psique ou da linguagem, pelo contrário, propõe um enredamento de agenciamentos heterogêneos de corpos, linguagem, julgamentos, técnicas e práticas.

De acordo com Domenèch, Tirado e Gómez (2001), a abordagem do "eu" como exterioridade a um evento linguístico termina por manter o dualismo sujeito/objeto e não escapa do logocentrismo e da circularidade de seu modo de entender a subjetividade.

Assim, os autores também lançam mão do pensamento deleuziano por afirmarem ser uma forma que permite pensar a subjetividade em movimento e continuamente produzida. Não consiste na demarcação de territórios ou limites de um eu que seria efeito de operações exteriores a si. Afirmam que "é preciso resistir à tirania do dispositivo linguagem-discursosignificado na hora de pensar a subjetividade" (p.123).

Nesse sentido, a linguagem se configura como apenas um dos elementos, entre vários, que compõem os diversos agenciamentos e ordenações em que estamos implicados. O importante é analisar a linguagem e seus efeitos como um dos inúmeros nós dessa trama. E não deve ser tomada como matéria prima única na constituição da subjetividade.

O linguístico e o discursivo certamente estabilizam relações e geram relações, mas não são, em essência, questões interacionais $\mathrm{e}$ interpessoais. O que torna possível qualquer relação ou intercâmbio é um regime de linguagem, incorporado em práticas que capturam os seres humanos sob diversas formas, inscrevem, organizam, formam a produção dessa mesma linguagem (Domenèch, Tirado \& Gómez, 2001, p.125).

Diante do exposto, pensar os processos de subjetivação como dobras implica em tirarmos do sujeito todas as possibilidades de rotulações identitárias essencialistas e interioridades absolutas. Somos convocados a reconhecer a constante transformação de criação que a subjetividade impõe e possibilita. As dobras nos permitem pensar em processos de subjetivação que vão além da pele, que transbordam dos corpos, cujo caráter é aberto, inacabado e cambiante.

Ao propor uma analogia com as dobras deleuzianas, Rose (2001a) se contrapõe à tendência de uma interioridade do sujeito. "A "interioridade" que tantos sentem-se compelidos a diagnosticar não é aquela de um sistema psicológico, mas de uma superfície descontínua, de uma espécie de dobramento, para dentro, da exterioridade" (p.49). A dobra indica que as 
relações são estabelecidas sem um interior essencial e que a relação com o dentro é apenas uma dobra do exterior.

Para discutir a invenção da Psicologia Social, Silva (2005) traz a noção de dobras da subjetivação capitalística. Para isso também lança mão da ideia de dobras deleuzianas. Nesse sentido, os múltiplos plissamentos do tecido social produzem diferentes modos de expressão da subjetividade.

O conceito de dobra pode fazer surgir um diagrama generalizável para pensar as relações, as conexões, as multiplicidades e as superfícies - sua formação de profundidades, singularidades, estabilizações. Esse diagrama da dobra descreve uma figura na qual o lado de dentro, o subjetivo, é, ele próprio, não mais que um momento, ou uma série de momentos, por meio do qual uma "profundidade" foi constituída no ser humano. A profundidade e sua singularidade não são, pois, mais do que aquelas coisas que foram escavadas para criar um espaço ou uma série de cavidades, plissados e campos que só existem em relação àquelas mesmas forças, linhas, técnicas e invenções que as sustentam (Rose, 2001b, p.179).

Retomando nosso objeto de estudo, a judicialização das relações conjugais, parece plausível afirmar que ao invés de nos questionarmos sobre que tipo de sujeitos são produzidos a partir da matriz da judicialização, devemos pensar nos efeitos que produzem em e para nossa sociedade. Nossa indagação não seria sobre que tipo de sujeito é produzido a partir dessa matriz, mas sim, o que ele produz e qual sua capacidade de afetar e de ser afetado.

Essa capacidade não é tampouco uma propriedade da carne, do corpo, da psique, da mente ou da alma. É, simplesmente, algo variável, produto ou propriedade de uma cadeia de conexões entre humanos, artefatos técnicos, dispositivos de ação e pensamento (Domenèch, Tirado \& Gómez, 2001, p.129).

Diante do exposto, entendemos que o modo como as relações violentas são tratadas (judicializadas) interfere nos modos de ser das pessoas envolvidas. As relações violentas são entendidas por Gregori (1993) como relações entre pessoas envoltas em assimetrias de poder. Desse modo, a autora propõe que não é suficiente tratar o problema da violência como se fosse algo apenas relativo ao casal. Devem ser consideradas as relações de poder entre os envolvidos.

Quando a leitura dos casos de violência de gênero enfatiza apenas a dualidade entre algoz e vítima, estabelece uma polaridade entre o ativo e o passivo e deixa de considerar as cenas nas quais os parceiros se veem envolvidos. A violência é motivada por várias razões, tais como: o não desempenho das atribuições de gênero prescritas e até os jogos eróticos.

Gregori (2003) enfoca a falta de diferenciação entre os relacionamentos violentos, que muitas vezes são tratados como se fossem todos semelhantes. Mais uma vez ela provoca ao propor que a violência pode ser uma forma de comunicação perversa entre os parceiros, e não apenas a imposição de um (homem) sobre o outro (mulher). Não buscou uma explicação para a violência, mas a compreensão de como as mulheres se veem nessas relações, como veem a si e a seus parceiros, além de problematizar como essas relações se constituem e se mantêm. Buscou entender a impossibilidade de descrever uma relação típica de violência conjugal, na medida em que não existem padrões que configurem as relações conjugais violentas.

Muitas vezes, a posição da mulher é bastante fluida, pois há um universo de referências que toma o masculino não apenas como complementar, mas também como definidor do que é o feminino. Assim, cabe à mulher alguns atributos associados à natureza, tais como os instintos e a feminilidade construída a partir do corpo. Tais aspectos terminam por restringir a mulher ao universo doméstico e da reprodução. O conjunto de referências da maioria das mulheres é o mesmo que o de seus agressores (parceiros). Embora se queixando da violência que sofrem, não conseguem (muitas vezes) negar a ordem moral que legitima tal violência. A relação estabelecida com aquele que agride é também de intimidade "um laço que supõe uma tensão, mas também uma simbiose entre ódio e amor" (Gregori, 1993, p.196). 
Com tais provocações não pretendemos apontar conclusões, nem tão pouco saídas para o problema da judicialização das relações conjugais violentas. Contudo, enfatizamos que apenas judicializar não dá conta desse problema que requer outras estratégias de enfrentamento. Desejamos a continuidade nos debates e reflexões para que possamos promover transformações. Que novas dobras sejam possíveis.

\section{Referências bibliográficas}

Butler, J. (2008). Problemas de gênero: feminismo e subversão da identidade. São Paulo: Civilização Brasileira, 2.ed.

Domènech, M.; Tirado, F. \& Gómez, L. (2001). A dobra: Psicologia e Subjetivação In: SILVA, T.T. D., (Org.). Nunca fomos humanos: nos rastros dos sujeitos (pp.137-234). Belo Horizonte: Autêntica.

Foucault, M. (1994) Technologies of the self. (Université du Vermont, outubro, 1982; trad. F. Durant-Bogaert). In: Hutton, P. H.; Gutman, H. \& Martin, L. H. (eds.) Technologies of the Self. A Seminar with Michel Foucault. Anherst: The University of Massachusetts Press, 1988, (pp. 16-49). Traduzido a partir de Foucault, Michel. Dits et écrits. Paris: Gallimard, 1994, Vol. IV, pp. 783-813, por Karla Neves e Wanderson Flor do Nascimento.

Gregori, M. F. (1993). Cenas e queixas: um estudo sobre mulheres, relações violentas e a prática feminista. Rio de Janeiro: Paz e Terra; São Paulo: ANPOCS.

Guattari, F. (1992/2008) Caosmose: um novo paradigma estético. São Paulo: Ed. 34, (5 reimpressão).

Medrado, B.; Méllo, R. P. (2008). Posicionamentos críticos e éticos sobre a violência contra mulheres. Psicologia e Sociedade, 20, Edição Especial, 78-86.

Méllo, R.P. D, Medrado, B. \& Bernardes, J. (2010). Dispositivo legal como tecnologia de governo da vida: usos e efeitos da Lei Maria da
Penha. In: Jobim e Souza, S. \& Moraes, M. (Org.) Tecnologias e modos de ser no contemporâneo (pp.127-156). Rio de Janeiro: Ed. PUC-Rio: 7 Letras.

Oliveira, R. M. (2005) Tecnologia e subjetivação: a questão da agência. Psicologia \&. Sociedade, 7, 56-60. Recuperado em 01 de Agosto, 2011, de:

http://www.scielo.br/scielo.php?script=sci_arttext\&pid=S0102-

$71822005000100008 \& \operatorname{lng}=$ en $\&$ nrm=iso

Revel, J. (2005). Michel Foucault: conceitos essenciais. Tradução Maria do Rosário Gregolin, Nilton Milanez, Carlos Piovesani. - São Carlos: Claraluz.

Rifiotis, T. (2004). As delegacias especiais de proteção à mulher no Brasil e a 'judiciarização' dos conflitos conjugais. Revista Estado $e$ Sociedade, Brasília, v. 19, n.1, 85-119, jan./jun.

Rifiotis, T. (2007). O Idoso e a Sociedade Moderna: desafios da gerontologia. Conferência proferida na VII Jornada de Inverno da Sociedade Brasileira de Geriatria e Gerontologia. Porto Alegre.

Rose, N. (2001a). Como se deve fazer a história do eu? Educação $e$ Realidade. Porto Alegre, v. 26, n.1, 34-57, jan/jun.

Rose, N. (2001b) Inventando nossos eus. In: Silva, T. T., (Org.). Nunca fomos humanos: nos rastros dos sujeitos (pp.137-204). Belo Horizonte: Autêntica.

Silva, R. N. da. (2005). A invenção da psicologia social. Petrópolis, RJ: Vozes. 


\section{Sujeito na Psicanálise: $O$ ato de resposta à ordem social}

\section{Patrícia do Prado Ferreira-Lemos ${ }^{1}$}

A noção de sujeito na Psicanálise emerge nas elaborações do psicanalista francês Jacques Lacan. Não há esta formulação na obra de Sigmund Freud, embora Lacan tenha cunhado o termo exatamente a partir da obra freudiana ancorando-se, especialmente, em suas experiências clínicas.

O sujeito aparece na obra de Lacan dando o estatuto ao falasser (Lacan, 1975), isto é, ao "individuo empírico que se submete à experiência e a instância que se deduz da mesma experiência, instância suposta ao saber inconsciente, ao inconsciente como saber" (Askofaré, 2009, p.166). O que isso quer dizer? Que o sujeito sobre o qual se ocupa a Psicanálise é, antes de tudo, o sujeito pensado a partir da concepção do inconsciente e é exatamente este ponto que marca a principal diferença entre as elaborações da Psicologia das da Psicanálise. Ao formular este conceito (esta era uma das maiores preocupações de Lacan) aponta o fato da primeira se apoiar nas elaborações da consciência e, portanto, do eu, enquanto que a segunda se refere a uma constituição que considera o inconsciente. Para Sidi Askofaré (2009), Lacan contesta a não historicidade do sujeito e abre uma perspectiva para a articulação entre estrutura e história. A historicidade do sujeito não é o norte na Psicanálise, mas os significantes são marcados pela história e compõem o inconsciente que é estrutural.

As elaborações sobre sujeito que existiam antes da formulação da qual nos ocupamos não permitiam que o sujeito pensado do modo como concebido pela Psicanálise fosse apreendido. Certamente, o que marca esta principal distinção é que na concepção anterior, de origem filosófica, o

\footnotetext{
${ }^{1}$ Bolsista pelo Conselho Nacional de Desenvolvimento Científico e Tecnológico (CNPq).
}

sujeito é identificado como o sujeito da consciência, representado, sobretudo pelo cogito cartesiano "Penso, logo sou". A elaboração está muito mais atrelada àquele que tem consciência de seus atos, consciência de si. Lacan propõe especialmente no texto Subversão do sujeito e dialética do desejo (1960/1998) um sujeito para-além da consciência, a partir do reconhecimento da estrutura da linguagem no inconsciente.

Buscamos formular neste texto a concepção lacaniana do sujeito consciente e do sujeito do inconsciente percorrendo especialmente as dimensões do imaginário e do simbólico, fundamentais para a sustentação da ideia. Entretanto, vale aqui ressaltar que Lacan posteriormente desenvolveu o para-além do simbólico, o campo do gozo, ao qual não nos ateremos nesta exposição.

\section{O outro em mim}

O encontro com a teoria freudiana é o ponto de partida para a construção lacaniana sobre o imaginário. Após quatro anos desta aproximação inicial com a teoria psicanalítica - que ocorre no momento da construção de sua tese em psiquiatria intitulada $\mathrm{Da}$ psicose paranoica em suas relações com a personalidade (1932), - sabe-se que Lacan discursa sobre o "estádio do espelho", no XIV Congresso Psicanalítico Internacional em Marienbad em 1936, na antiga Tchecoslováquia, mas não há um texto transcrito deste momento. Esta elaboração é, reconhecidamente, a mais notável de Lacan sobre o conceito de imaginário.

Dois anos depois, Lacan (1938/1997) desenvolve sobre o "complexo de intrusão", indicando-o como palco de conflito nas relações intersubjetivas. Neste complexo, a rivalidade de um irmão no nascimento do outro é causa de angústia para o irmão mais velho, que se interroga sobre o lugar que o irmão por vir ocupará no desejo da mãe, no desejo do Outro. Existe, entretanto, uma dualidade de sentimentos, pois há "identificação imaginária", também presente na relação que se estabelece, como veremos, a partir do estádio do espelho com seus semelhantes, os outros. Relação tão 
conflituosa que Freud (1927) descreve como uma das três principais fontes de angústia que atravessam o sujeito.

Posteriormente, a formulação sobre o estádio do espelho é novamente apresentada na comunicação realizada em Zurique, na Suíça, dando origem ao texto O estádio do espelho como formador da função do eu (1949/1998).

O estádio do espelho condiz com o momento em que o bebê - entre os seis e dezoito meses de vida - percebe pela primeira vez sua imagem refletida no espelho, concebendo uma unificação do corpo através da imagem de si ou do outro:

o estádio do espelho é um drama cujo impulso interno precipitase da insuficiência para a antecipação - e que fabrica para o sujeito, apanhado no engodo da identificação espacial, as fantasias que sucedem desde uma imagem despedaçada do corpo até uma forma de sua totalidade que chamaremos de ortopédica e para a armadura enfim assumida de uma identidade alienante, que marcará com sua estrutura rígida todo o seu desenvolvimento mental. (Lacan, 1949, p.100).

Assim, este momento de imagem refletida no espelho, marca a separação do Innenwelt com o Umwelt, o mundo interno e o mundo externo. O mundo interno será agora apropriado através de identificações com o mundo externo, que lhe serão oferecidas por aquele que ocupa o lugar de Outro, isto é, por aquele no qual encontro a minha representação. Aqui, desvela-se a necessidade de se ser mediatizado pelo desejo do Outro, afinal é o Outro quem diz "você é este no espelho", marcando o destino do sujeito. O sujeito se reconhece no espelho através do Outro, instaurando-se o eu, desde sempre narcísico, e será a imagem refletida, o eu ideal, base das identificações que acompanharão o sujeito daqui por diante. Fixa-se uma imagem mental do eu que acarreta o seu fado alienado, como coloca Lacan:

É essa imagem que se fixa, eu ideal, desde o ponto em que o sujeito se detém como ideal do eu. O eu, a partir daí, é função de domínio, jogo de imponência, rivalidade constituída. Na captura que sofre de sua natureza imaginária, ele mascara sua duplicidade, qual seja, que a consciência com que ele garante a si mesmo uma existência incontestável (...) não lhe é de modo algum imanente, mas transcendente, uma vez que se apoia no traço unário do ideal do eu (...). Donde o próprio ego transcendental se vê rivalizado, implicado como está no desconhecimento em que se inauguram as identificações do eu (Lacan, 1960/1998, p.823).

A criança irá se identificar com este objeto fixo que se mostra com uma aparência unificada, mais semelhante à ideia que tem de seus pais ou de seus cuidadores, que lhe parecem muito mais capazes, poderosos e coordenados que ela. É também neste momento que a fala do Outro parental como "boa menina", "menino de ouro", "filha má" é internalizada. A imagem que reflete no espelho acompanhada do discurso do Outro e que, portanto, é estruturada linguisticamente, compõem o que a criança percebe como seu eu (self). O eu será preenchido por imagens ideais e, certamente, terá outras imagens agregadas ao longo da vida (Fink, 1998):

Na realidade, é a ordem simbólica que realiza a internalização das imagens especulares e de outras imagens (por exemplo, imagens fotográficas), uma vez que é essencialmente devido à reação dos pais a tais imagens que elas se tornam carregadas de interesse ou valor libidinal aos olhos das crianças (Ibid., p. 57).

Em Observação sobre o relatório de Daniel Lagache (1960/1998), Lacan utiliza a ilusão do buquê invertido de Bouasse para mostrar de maneira analógica a relação do eu com o outro e a incidência do imaginário e do simbólico. 


\section{Esquema do buquê invertido}

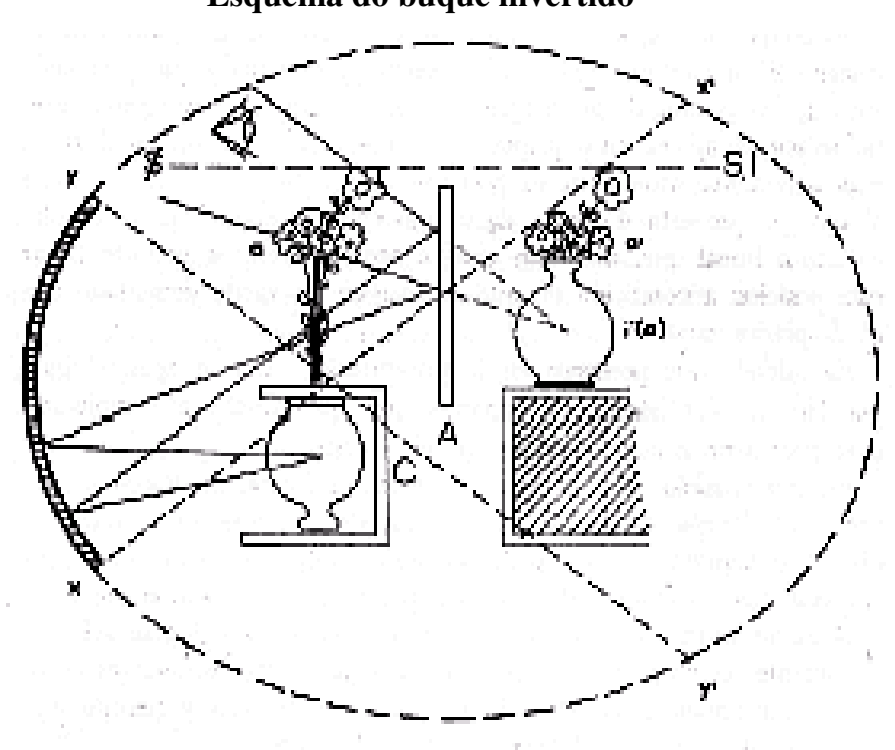

As imagens ópticas apresentam diversidades singulares - algumas são puramente subjetivas, são as que se chamam virtuais, enquanto outras são reais, a saber, sob certos prismas, se comportam como objetos e podem ser tomadas como tais. Muito mais singular ainda - esses objetos que as imagens reais são, podemos dar as suas imagens virtuais. Nesse caso, o objeto que é a imagem real toma, e devidamente, o nome de objeto virtual (Lacan, 1953-1954, p.93).

No experimento do buquê invertido um espelho esférico produz uma imagem real, uma vez que cada ponto de raio luminoso que emana de um ponto qualquer de um objeto colocado à determinada distância, preferencialmente no plano central da esfera, irá corresponder ao mesmo plano, por convergência dos raios que são refletidos sobre a esfera. É este processo que dá ao objeto uma imagem que se pode considerar real. Aqui, o buquê é colocado escondido dentro de uma caixa oca, enquanto o vaso está sobre ela. Com a projeção das imagens na superfície esférica tem-se a forma da imagem real, que é a do buquê dentro do vaso. Trata-se, logo, de um buquê imaginário, isto é, de uma impressão da realidade. É desta mesma forma que o eu se constrói, com a imagem que vê refletida no espelho, ou seja, a partir de imagens virtuais que o representam.

Žižek (2006) coloca que é como se tratasse de um rolo de filme preso. A imagem especular congela o movimento, somente dando visibilidade à imobilidade. Logo, esse olhar imaginarizado só permite ver os objetos de forma petrificada. O olhar não só mortifica os objetos como constitui um ponto congelado de não movimento.

Antônio Quinet (2004), em Um olhar a mais, ressalta no pensamento de Lacan exatamente a relevância do olhar no estádio do espelho, indicando que o olhar em questão é o do Outro, o olhar que a criança busca e que ao se cruzarem - o olhar da criança e do Outro - tornam-se um só olhar, razão para júbilo. O espelho no qual a criança se vê é o Outro e são as respostas desse Outro, ideal do eu, que dão forma ao eu ideal. Assim, ao ter o Outro como seu endereçamento - aquele que vê - e o gozo em ser visto, temos o par da pulsão escópica: o voyeurista e o exibicionista.

O entendimento de imaginário em Lacan, em 1949, rompe com os sentidos dados anteriormente pela Filosofia de Platão a Spinoza, onde se acredita que o imaginário é o que nos leva ao engano, colocando-o em relação com o que é ilusório; a concepção poética relaciona-o ao irreal, mágico ou místico e o sociológico, concebe-o enquanto aquilo que faz parte de um coletivo, imaginário próprio de cada cultura. Lacan quebra com essas três ideias e retorna à ideia do imaginário relacionado à imago, a gestalt, que é o que está implícito Morphè (forma) de Aristóteles, que considera a imagem como uma representação mental de um objeto.

A primeira elaboração do estádio do espelho prepondera na obra de Lacan por quase duas décadas, mas este estatuto será revisitado a partir do momento em que o simbólico torna-se extremamente relevante, marcado pela Conferência de 1953, que abordamos nesta segunda parte. 


\section{$O$ inconsciente estruturado como uma linguagem}

Em seus artigos Função e campo da fala e da linguagem em psicanálise (1953/1998) e A instância da letra no inconsciente ou a razão desde Freud (1957/1998), Lacan aborda as formulações acerca do inconsciente estruturado como linguagem, entrelaçando com as ideias dos linguistas Ferdinand Saussure e as de Jakobson - especialmente em $A$ instância da letra. Tal proximidade, por sua vez, marca o retorno à própria obra freudiana, que naquele momento encontrava-se, predominantemente, relacionada à Psicologia do eu e às teorias pós-freudianas. Neste sentido, a abordagem lacaniana continua seu trabalho de ênfase no descentramento freudiano da consciência enquanto origem da subjetividade. Da mesma forma que, enfatizando a causação lógica, rompe com as concepções sobre o sujeito marcadas pelo empirismo, mentalismo e substancialismo - ou seja, das teorizações da ciência, da sociologia e da filosofia, conforme expusemos na primeira parte do texto.

A afeição de Lacan pelo estruturalismo é um duplo movimento que o inflexiona tanto de volta a Freud quanto, em certo sentido, rumo a uma nova investidura teórica.

Lacan formula, assim, a sua construção do inconsciente estruturado como uma linguagem, e para retomá-la abordamos, tal como o fez, a elaboração de Saussure acerca do significante.

$\mathrm{Na}$ explicação do linguista, o signo é definido a partir da relação entre significado e significante, ou seja, a partir de uma relação entre o conceito e a imagem material acústica, o som. O significante, deste modo, irá atender à função de bancar o significado, escrito por um algoritmo marcado pela elipse que simboliza a unidade estrutural do signo e por uma barra, que indica a resistência à significação:

No Curso de Linguística Geral (1916/2006, p.81) há a seguinte representação que, sabemos, não foi de sua autoria, mas de seus alunos que organizaram o livro:
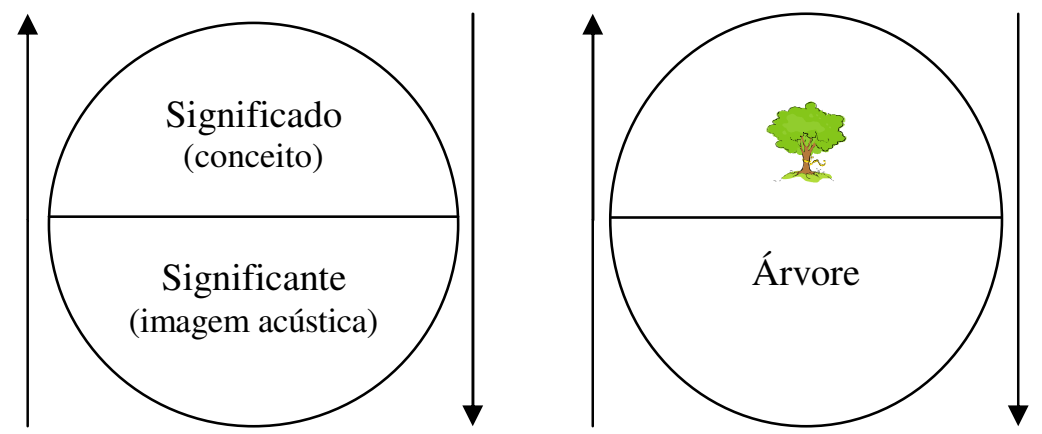

Existe nesse algoritmo (S/s) - que trata do signo linguístico - a indicação de setas que recomendam uma relação de reciprocidade e associação. Os dois elementos são combinados, um responde ao outro.

Lacan (1957/1998) acredita que sustentar essa ideia - de que o significante atende à função de representar o significado - é uma ilusão, pois de acordo com o psicanalista, as coisas não podem fazer mais que demonstrar que nenhuma significação pode se sustentar a não ser pela remissão a outra significação. Não existe uma significação em si, fechada e recíproca, pois "não há língua existente à qual se coloque a questão de sua insuficiência para abranger o campo do significado, posto que atender a todas as necessidades é um efeito de sua existência como língua" (ibid., p. 501). Deste modo, Lacan inverte o S, algoritmo da linguística e escreve:

$$
\frac{\text { significante }}{\text { significado }} \text { ou } \frac{\mathrm{S}}{\mathrm{S}}
$$

Propondo assim, a relação significante/significado, justificado pelo fato de que existe uma primazia do significante, que é produzido de acordo com sua articulação a outros significantes, não em associação a um significado:

$$
\mathrm{S}^{1}, \mathrm{~S}^{2}, \mathrm{~S}^{3} \ldots \mathrm{Sn}
$$


E é a partir dessa sua construção que se pode dizer que Lacan está afirmando que o significante é material, mas não uma substância. Uma combinatória entre significantes arranja o que em Psicanálise se conhece por cadeia significante, isto é, da articulação de $S^{1}-S^{2}-S^{3}-S n$... emerge esta cadeia:

No campo freudiano, apesar das palavras, a consciência é um traço tão caduco, para basear o inconsciente em sua negação (...) $\mathrm{O}$ inconsciente, a partir de Freud, é uma cadeia de significantes que em algum lugar (numa outra cena, escreve ele) se repete e insiste, para interferir nos cortes que lhe oferece o discurso efetivo e na cogitação a que ele dá forma (Lacan, 1960/1998, p.813).

Em O eu na teoria de Freud e na técnica da psicanálise, Lacan (1954-1955, p.307) apresenta o esquema L. Trazemos aqui este esquema para que possamos entender melhor como o significante (a relação simbólica), é fundamental para a constituição do sujeito e, por consequente, para as relações que estabelece com o Outro e o objeto:

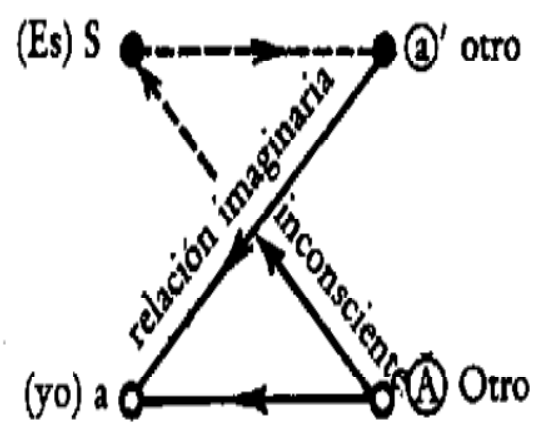

Neste esquema, que obedece também às regras estruturalistas, é indicado que a construção do eu (a) é imaginária - como vimos. Entretanto, o esquema L está também amplamente relacionado à construção simbólica, exatamente pela relação insconsciente existente entre o sujeito (S) e o Outro (A). O lugar do Outro deve ser entendido como o locus do simbólico, e portanto, como o locus dos significantes, inclusive dos significantes recalcados que retornam ou não para o sujeito. O discurso do Outro - que nos diz Lacan ser exatamente o que define o insconsciente - só chega ao sujeito fragmentado, em pedaços, simbolizado no esquema pelo pontilhado, pela falha. Isso acontece exatamente porque esse discurso é atravessado pela relação imaginária, como vemos na figura. A relação imaginária mascara a relação simbólica.

No esquema está inscrito o circuito do significante partindo do Outro, no entanto, ocorre que é o sujeito que recebe do Outro a sua própria mensagem invertida. Isso faz Lacan afirmar que o sujeito do qual estamos tratando é o sujeito não em sua totalidade, mas em sua abertura. "Como de costume, ele não sabe o que diz. Se ele soubesse o que diz não estaria aí. Ele estaria ali, embaixo, à direita" (Lacan, 1954-1955, p.307). Não saber o que diz está associado a sujeição do sujeito à linguagem, ou melhor, ao muro da linguagem. Assim, o sujeito que não sabe o que diz, torna-se, em sua relação especular, o a (eu) e é exatamente por isso que se pode dizer que o sujeito tem um eu (Idem).

A situação do sujeito é caracterizada pelo lugar que ele (sujeito) ocupa no mundo simbólico, na sua fantasia do desejo do Outro. É desse lugar no simbólico que dependem a relação do imaginário e do real e, consequentemente, a própria constituição de mundo do sujeito. Lacan diz que "o homem passa pela experiência de que se vê, se reflete e se concebe como outro que não ele mesmo - dimensão essencial do humano, que estrutura toda a sua vida de fantasia" (Lacan, 1953-1954, p.96).

Quinet nos ajuda a compreender este ponto ao dizer que o espelho tem a função de um anteparo ao inconsciente, uma barreira que "o imaginário do olho da consciência é uma cortina à determinação simbólica" (Quinet, 2004, p.130). Portanto, o sujeito não é senhor em sua própria morada, como nos advertiu Freud. O sujeito está sempre referenciado ao Outro, à deliberação simbólica que o constitui, à imaginarização que o permite enxergar o mundo e ao real, do qual só é possível sentir seus efeitos:

A economia imaginária não nos é fornecida no limiar de nossa experiência, não se trata de uma vivência inefável, não se trata de procurar uma melhor economia das miragens. A economia imaginária só tem sentido, só podemos influir nela, na medida em 
que se inscreve numa ordem simbólica que impõe uma relação ternária (Lacan, 1954-1955, p.320-1).

O esquema $\mathrm{R}$, apresentado por Lacan em De uma questão preliminar (1958/1998) complementa os dois esquemas (L e Buquê), demarcando onde se encontra a realidade (R). Como se pode perceber, a realidade está situada no espaço correspondente a $a-a^{\prime}$, isto é, ao eixo imaginário do esquema $\mathrm{L}$.

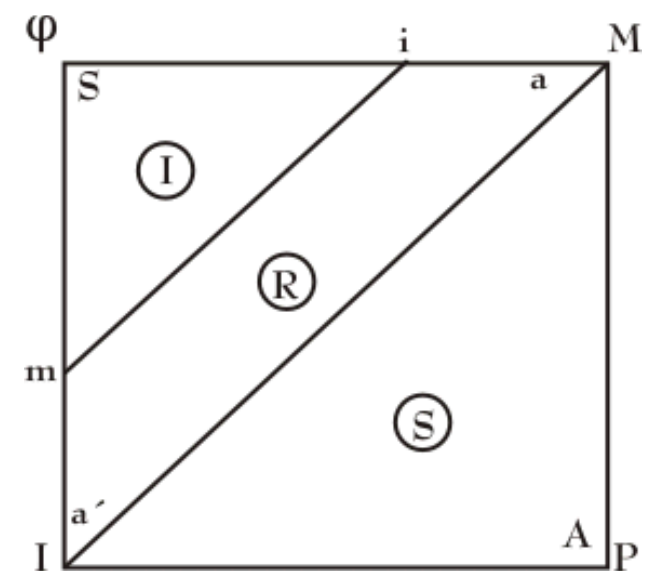

Esquema R

Lacan demonstra um triângulo correspondente ao simbólico (S) tendo I (ideal do eu), M (mãe ou significante do objeto primordial) e P, como a posição do Outro (A) no Nome-do-Pai - e um quadrilátero correspondente ao campo da realidade, delimitado por $\mathrm{M}, i, m$ e I, onde se tem $i$ e $m$ como representante dos termos imaginários da relação narcísica: o eu e a imagem especular. Lacan afirma que a escolha das letras não foi por acaso, pois mi e MI ocupam o mesmo lugar topológico, o que nos permite dizer que a topologia da realidade é dada como uma banda de Moebius, pois no lugar que se aparenta ter duas bordas, tem-se uma só. A metáfora da banda de Moebius sugere, igualmente, que ideal do eu, significante do objeto primordial, eu e imagem especular participam de uma mesma espiral, sendo que um conectase ao outro, age com o outro, dando origem à realidade do sujeito, a partir da extração do objeto $a$, que é exatamente o que fornece seu enquadre.
O objeto a vem em resposta à questão do desejo do Outro, do que quer ele de mim. O sujeito responde a esta questão, colocando-se enquanto objeto causa de desejo do Outro, o que dá o aparato para pintar a sua realidade, sendo o suporte de todas as suas causas, o que delega ao sujeito uma condição inerente de passividade frente ao objeto. Aqui, o objeto a tem esta função de resposta a uma questão, mas ele está também relacionado à dinâmica do simbólico e do real, tanto que aloja no nó borromeo - topologia lacaniana que, grosso modo, articula as três estruturas - no lugar de encaixe dos três elos, onde o buraco de um conjuga-se com o buraco do outro.

Žižek (2007) utiliza-se de uma piada para explicar esse funcionamento que tentamos elucidar. A piada é de um louco que acredita ser um grão de milho. Ele fica um longo tempo em tratamento e um dia recebe alta por estar totalmente curado. A família comemora a sua recuperação. Um dia, o então "ex-louco" encontra-se com uma galinha e corre para se esconder debaixo da cama. A mãe, assustada, pergunta por que ele se escondeu se já não é mais um grão de milho e então, ele responde "eu sei, mãe, mas será que a galinha sabe?". Para Lacan (1958) tanto na psicose como na neurose a condição do sujeito depende da relação que estabelece com o Outro (A). Assim, surge a questão "O que sou eu aí?", onde o sujeito encontra-se no lugar de sua inefável e estúpida existência, tendo como objeto os outros (objetos ou ele mesmo) e o Outro como lugar onde se pode colocar a questão de sua existência. “O que a galinha quer de mim?", é a pergunta que o louco se faz.

O sujeito se aliena, portanto, nos significantes da demanda e é neste sentido que podemos considerá-lo enquanto efeito, uma resposta à ordem simbólica.

\section{Sujeito do enunciado e o sujeito da enunciação}

Por certo, a exposição que precede esta parte do texto é importante para que possamos, finalmente, nos atermos propriamente à questão do sujeito na Psicanálise. Como colocado, existe uma preocupação por parte de Lacan em marcar uma diferença entre as concepções da Psicanálise e às da 
psicologia do eu. Este é o ponto de partida da elaboração do conceito e, com efeito, também nossa preocupação neste momento.

Entretanto, torna-se fundamental reforçar, como o fez Luciano Elia em 'O Conceito de Sujeito' (2007), que Lacan afirma "o sujeito sobre o qual operamos em psicanálise não pode ser outro que não o sujeito da ciência". Isto significa, diz Elia, que na Psicanálise operamos sobre um sujeito e que na ciência há um sujeito sobre o qual a ciência não opera, embora se aproprie dele. Não se opera na Psicanálise sobre uma pessoa humana, aí se situa a subversão própria à Psicanálise, no sentido de ter criado condições para se operar com o sujeito:

Que o sujeito sobre o qual opera seja o sujeito da ciência, segundo uma fórmula em vias de tornar-se um refrão, não quer dizer nada além de que a invenção da psicanálise, bem como seu exercício e sua transmissão, são determinadas pelas condições do discurso (Askofaré, 2009, p.174).

Lacan define o sujeito do enunciado como um shifter, aquilo que designa o sujeito enquanto ele fala naquele momento (Lacan, 1960/1998, p.814). O sujeito do enunciado é também aquilo que definimos como eu, que emerge de uma ideia de imagem unificada, de uma dimensão que se coloca a partir do equivoco provocado pela imagem no espelho, pelo malentendido. $\mathrm{O}$ "eu" é construído a partir destas imagens e é representado pelo sujeito do enunciado, sendo, portanto, o lugar de onde o sujeito se relaciona com os outros (como vimos no esquema $\mathrm{L}$ ), mas que está referenciado pelo simbólico e, portanto, a outra cena, que diz respeito ao lugar discurso do Outro, do inconsciente. O sujeito do enunciado designa o sujeito da enunciação, mas não o significa; todo significante do sujeito da enunciação pode faltar no enunciado, além de haver os que diferem do [Eu] (Lacan, 1960/1998, p.814).

O sujeito do enunciado é o que está posto na concepção de sujeito no cogito cartesiano: Cogito, ergo sum ou "Penso, logo sou". A existência do sujeito cartesiano é efêmera, ele é toda vez que diz para si que pensa. $\mathrm{O}$ pensamento para Descartes, que faz da dúvida seu método, é um processo consciente, para a Psicanálise, quando o eu é o autor das ideias, o pensamento é entendido como racionalização. Na concepção lacaniana de sujeito não é possível ser e pensar, "penso onde não sou, logo sou onde não penso. (...) O que cumpre dizer é: eu não sou lá onde sou joguete de meu pensamento; penso naquilo que sou lá onde não posso pensar" (Lacan, 1957/1998, p.521).

Essa divisão do sujeito entre eu e inconsciente marca sua estrutura e o define enquanto tal. O sujeito é barrado, como afirma Lacan e simboliza por S, para dizer desta divisão a partir de seu encontro com a linguagem, que o coloca na condição de efeito e de produção significante.

É assim que se dá, portanto o sujeito da psicanálise, da enunciação ou do inconsciente. Este sujeito não é pensamento, ele não é construído, não nasce e não se desenvolve (Elia, 2007). O sujeito da psicanálise é constituído, como vimos, a partir do campo da linguagem, do simbólico. Ele, o sujeito, só é possível exatamente porque entra na ordem social que quase sempre precede sua chegada e tem a família como porta de entrada (ibid.). É deste ponto que podemos pensar que a constituição do sujeito está atrelada ao campo social e isso é uma condição para sua existência enquanto tal.

É a partir da ruptura que coloca o sujeito na cultura que se dá não só a constituição como sujeito, mas também o institui enquanto humano. Isto que nos tira a natureza, nos marca enquanto faltantes, isto é, como seres vivos marcados pela falta no nível do ser. Como escreve Elia: "trata-se de uma condição que comporta algo de paradoxal: a falta é fundante do sujeito, mas, em contrapartida, requer o ato do sujeito para se fundar como falta" (Elia, 2007, p.48).

Além disso, sem o aparato do campo social o sujeito não sobrevive, pois, como se sabe, ele precisa do cuidado do próximo. Esta condição de necessidade do outro para a vida é o que Freud denomina de "desamparo fundamental". A qualidade de desamparado que necessita dos cuidados de um estranho é também o que faz emergir o Outro, que significa não só o cuidador, pessoa física, como também a própria ordem social que é 
introduzida através deste que tenta amparar. O Outro que cuida é um ser de linguagem, que irá atender ás necessidade específica de fome, por exemplo, mas que também trará o significante, a palavra.

É a partir desta relação que a necessidade (para a Psicanálise, trata-se de uma experiência mítica, pois nunca a experimentamos sem a mediação da linguagem) dá lugar a demanda - que introduz e é introduzida pelo Outro diante do qual a criança se situa. O bebê, portanto, demanda ao Outro aquilo que traz para atender a fome, mas também sua presença, seu amor. O bebê relaciona-se com este Outro capaz de trazer o objeto de sua necessidade e, deste modo, exclui o que poderia haver de natural no objeto da necessidade. Ao mesmo tempo em que se dirige ao Outro, o bebê é também impelido por algo, uma força, em direção a um objeto que não tem forma, mas que o impulsiona. Lacan denominou este objeto perdido no encontro com a linguagem, de objeto $a$. Este objeto é o que está por detrás de todo objeto com o qual o sujeito se relaciona, se firmando como objeto causa de desejo, isto é, o objeto perdido, a falta inaugural, é o que move o sujeito em direção aos outros objetos. Mas, claro, não é qualquer objeto que se faz interessante. Os objetos se tornam desejáveis na medida em que alguma característica significante se relaciona com a cadeia significante do sujeito

Portanto, a trama do significante se dá neste encontro do sujeito com o Outro, assim como é deste encontro que sujeito e Outro passam a existir deste modo. Há aqui um significante primordial, que chamamos de S1, e que será condicional para a estrutura da cadeia significante do sujeito. Lacan (1960/1998) afirma que o Outro, como sítio prévio do puro sujeito do significante, ocupa a posição mestra antes mesmo de ter acesso a existência; o código do sujeito é o código do Outro, isto é, é do Outro que o sujeito recebe a mensagem que emite, como apontado no esquema L. É também a partir do desejo do Outro que se dá o desejo do sujeito: "é como Outro que ele deseja" (Lacan, 1960/1998, p.829). Assim, a pergunta que retorna para o sujeito, indicando o caminho para seu desejo, pode ser formulada como Che vuoi?, "que quer você?".
Pois bem, diante do que expusemos enquanto constituição do sujeito e a sua diferença em relação ao eu, podemos finalmente entender o modo como a Psicanálise opera sobre o sujeito. Como inicialmente trouxemos, o conceito de sujeito remete-se à obra de Jacques Lacan, mas é a experiência clínica detalhada por Freud em sua obra, que permite a construção do conceito.

Se retomamos os escritos freudianos, encontramos em seus casos o que podemos entender como o sujeito do inconsciente, uma vez que emerge nos tropeços da fala, nos furos do discurso, isto é, nos lapsos da língua, atos falhos, chistes e até mesmo no sintoma. São os casos clínicos que apontam para este lugar, como podemos perceber no caso da Senhorita Elisabeth Von R., paciente de Freud.

Elisabeth chega a Freud diagnosticada como histérica, o que foi confirmado por ele e que acrescentou tratar-se de histeria de conversão. A paciente tinha 24 anos e apresentava, há mais de dois anos, dores nas pernas e dificuldades para andar. Na sua história de vida havia o cuidado com outras pessoas: seu pai havia ficado doente por 18 meses até a morte, sua mãe apresentava sérios problemas na vista e uma irmã mais velha havia morrido em decorrência de um problema cardíaco. Elisabeth era a caçula de três irmãs e possuía um laço terno estreito com os pais, especialmente com o pai, que costumava dizer que a filha ocupava lugar de filho e amigo. Isto a afetava, pois se mostrava descontente por ser mulher e tinha fantasias absolutamente ambiciosas para a época. Ela queria estudar e não se sentia inclinada em ocupar o lugar de esposa em um casamento. Foi durante este período da doença, que levou seu pai, que Elisabeth diz ter sentindo, pela primeira vez, as dores descritas, tendo ficado um dia e meio de cama por isso. Entretanto, só dois anos depois do pai ter falecido que, de fato, ficou sem andar por causa das dores, principalmente no pé.

Posteriormente à morte do pai, ocorreram os casamentos de suas irmãs mais velhas. A primeira casou-se com um homem que parecia poder lhe oferecer uma boa vida, e o casal se mudou da cidade, fato que acarretou em um sentimento de desamparo em Elisabeth, especialmente porque se deparou com a impossibilidade de concretizar seu ideal de ter uma família feliz, 
mesmo com a falta do pai. A segunda irmã também se casou, e ainda que com uma pessoa menos inteligente, possuía um comportamento em relação às outras pessoas que agradava muito à Elisabeth e sua família. Isto inclusive fez com que o casamento fosse visto com outros olhos pela paciente.

Toda a família de Elisabeth se reuniu em uma estação de veraneio para que ela descansasse dos exaustivos cuidados aos outros. Foi então que seus sintomas se instauram. Tempos depois, sua irmã - casada com o cunhado "dos olhos" de Elisabeth - que estava grávida, morre. Freud ouve Elisabeth por um tempo, sempre atento às causas de seu sintoma e insistindo para que ela lhe dissesse tudo o que lhe passasse pelos pensamentos, sem se censurar. A partir desta técnica, da associação livre, chega ao esclarecimento do que provocara as dores em Elisabeth. O passeio à estação de veraneio é realmente o ponto central, pois ali, fica evidente, para Elisabeth, seu carinho e afeto pelo cunhado. Na ocasião da morte de sua irmã, no entanto, o pensamento de que ele agora estava livre e poderia se casar com ela, também lhe fora insuportável.

Assim, Freud considera que as dores de Elisabeth não tinham uma só origem. Elas decorriam de uma sucessão de eventos traumáticos, que se reuniam neste sintoma. A morte do pai lhe causara as dores que a estavam concentradas exatamente no lugar onde o pé de seu pai tocava suas coxas enquanto lhe cuidava. E, não conseguir ficar de pé (to stand), associava-se ao seu sentimento de desamparo, receio de "ficar só", especialmente relacionado ao fato de não conseguir estabelecer uma nova vida à sua família, não conseguindo mesmo "dar um único passo à frente”. Em inglês, como apontado na nota de roda pé deste texto de Freud, o verbo to stand tem sua tradução como "erguer-se sozinha" ou "ficar de pé sozinha". Freud associa a dor física à palavra falada, isto é, ao significante:

Em vista disso, fui forçado a supor que entre as influências que contribuíram para a formação de sua afasia, tiveram papel essas suas reflexões; não pude deixar de pensar que a paciente não fizera nada mais nada menos do que procurar uma expressão simbólica para seus pensamentos dolorosos, e que a encontrara na intensificação de seus sofrimentos. (...) Por conseguinte, essa afasia, na fase de desenvolvimento que encontrei, devia ser igualada não só a uma paralisia baseada em associações psíquicas, mas também a uma paralisia baseada na simbolização (Freud, 1893-1895, p.176-177).

A histeria de conversão de Elisabeth nos diz de um excesso de simbolização que se escreve no corpo, lhe tirando a capacidade de caminhar. A paciente não aceitava seus pensamentos relacionados ao cunhado, recalcando seu desejo, mas fazendo sintoma. Esta é a trama de real, simbólico e imaginário, é deste modo que, Elisabeth, o sujeito barrado relaciona-se com o objeto de seu desejo, o objeto $a$. A ideia insuportável de desejo pelo seu cunhado, da ordem do real, do furo, que é recalcado, aparece de outro modo, no simbólico, se apossando do corpo, impedindo que Elisabeth fique de pé, e no imaginário enquanto a admiração fraternal por seu cunhado. Elisabeth é "prensada" por estas três dimensões, como os são todos os sujeitos:

Ao conceber a histeria como o encadeamento de "símbolos" (significantes) ou "ideias limítrofes" - "ideias patogênicas" ou "extravagantes" - que se apossam do corpo, Freud define a causal da histeria como "uma relação simbólica". Na discussão do caso de Fräulein Elisabeth Von R., Freud afirma que a simbolização é meio caminho entre a autossugestão e a conversão, e que "a histeria restaura o significado original das palavras" (Freud 18935). Um sintoma histérico de dor precordial, por exemplo, pode corresponder à ideia não enunciada, ou melhor, enunciada no corpo: "apunhalou-me até ao coração" (Pollo, 2003, p.33).

É assim que vemos na clínica a emergência do sujeito do inconsciente, que irá se manifestar de uma forma efêmera, mas, com efeito. $\mathrm{O}$ processo de análise é o meio pelo qual se pode ter alguma referência do pensamento inconsciente, uma vez que a técnica da associação livre proporciona que o eu ceda lugar e que o sujeito do inconsciente "apareça". É deste modo que a Psicanálise pode operar sobre o sujeito que emerge do simbólico. 


\section{Referências bibliográficas}

Askofaré, S. (2009). Da subjetividade contemporânea. A Peste: revista de psicanálise e sociedade. São Paulo: EDUC. 1 (1). 165-175.

Elia, L. (2007). O conceito de sujeito. Rio de Janeiro: Jorge Zahar Ed.

Fink, B. (1998). O sujeito lacaniano: entre a linguagem e o gozo. Rio de Janeiro: Jorge Zahar Ed.

Freud, S. (1996) Edição Standard Brasileira das Obras Psicológicas Completas de Sigmund Freud. $2^{\mathrm{a}}$ Ed. Rio de Janeiro: Imago.

(1893-1895). Estudos sobre a histeria. vol. II.

(1927). O futuro de uma ilusão. vol. XXI.

Lacan, J. (1932/1987). Da psicose paranoica em suas relações com a personalidade, seguido de Primeiros escritos sobre a paranoia. Rio de Janeiro: Forense-universitária.

(1938/1997). Os complexos familiares na formação do indivíduo: ensaio de análise de uma função em psicologia. Rio de Janeiro: Jorge Zahar Ed.

(1949/1998). O estádio do espelho como formador da função do eu. Escritos. Rio de Janeiro: Jorge Zahar Ed.

(1953/1998). Função e campo da fala e da linguagem em psicanálise. Escritos. Rio de Janeiro: Jorge Zahar Ed.

(1953- 1954/1986). O Seminário, livro 1: Os escritos técnicos de Freud. Rio de Janeiro: Jorge Zahar Ed.

(1954-1955/1985). O Seminário, livro 2: O eu na teoria de Freud e na técnica da psicanálise. Rio de Janeiro: Jorge Zahar Ed.
(1960/1998). Subversão do sujeito e a dialética do desejo no inconsciente freudiano. In: Escritos. Rio de Janeiro: Jorge Zahar Ed.

(1960/1998). Observação sobre o relatório de Daniel Lagache Escritos. Rio de Janeiro: Jorge Zahar Ed.

. (1958/1998). De uma questão preliminar a todo tratamento possível da psicose. Escritos. Rio de Janeiro: Jorge Zahar Ed.

. (1957/1998). A instância da letra no inconsciente ou a razão desde Freud. Escritos. Rio de Janeiro: Jorge Zahar Ed.

Pollo, V. (2003). Mulheres Histéricas. Rio de Janeiro: Contra Capa.

Quinet, A. (2002/2004) Um olhar a mais: ver e ser visto na psicanálise. Rio de Janeiro: Jorge Zahar Ed.

Saussure, F. (1916/2006) Curso de Linguística Geral. São Paulo: Cultrix.

Žižek, S. (2006). Lacrimae Rerum - Ensayos sobre cine moderno y ciberespacio. Buenos Aires: Debate.

(2007). El acoso de las fantasías. Buenos Aires: Siglo XXI Editores. 


\section{O cuidado em saúde mental e a noção de sujeito: Pluralidade e movimento}

\section{Emanoel José Batista de Lima ${ }^{1}$}

\section{Introdução}

$\mathrm{P}$

roduzir um texto de caráter teórico-científico requer, de quem o escreve, uma série de cuidados e algumas considerações. René Lourau (2004), um dos construtores do campo conhecido como Análise Institucional, ao propor o conceito de implicação, denunciou a falsa ideia da pretensa neutralidade científica ao indicar que o observador, desde a eleição de objetos, encontra-se implicado com o âmbito a ser observado; apontava que os processos de análise provocam transformações nos espaços institucionais de investigação e/ou de intervenção.

Segundo Lourau (ibid.), o sujeito que se põe em processo de investigação/intervenção encontra-se implicado em termos afetivos, econômicos, ideológicos e epistemológicos com o campo que se interessa. Como consequência, devemos analisar a implicação que estabelecemos com os territórios de análise, pois tal procedimento acaba se configurando como um ponto de reflexão ética para os processos de produção de conhecimento. Dessa maneira, a análise da implicação se torna fundamental em função das reverberações ético-políticas do que a implicação em si, a relação entre o sujeito e o campo que se debruça deve ser o foco desta analítica.

O sujeito investigador deve pôr em questão suas vinculações institucionais, seu posto de saber-poder perante o mundo, seu posicionamento na vida social e estar consciente que também é objetivado pelos âmbitos que se propõe a examinar, sejam eventos sociais, fatos institucionais,

\footnotetext{
${ }^{1}$ Bolsista pela Fundação de Amparo à Pesquisa do Estado do Piauí (FAPEPI).
}

representações das mais diversas ordens, grupos, movimentos sociais etc. Tais mobilizações possibilitam ao sujeito problematizar o objetivismo científico tradicional, o que pode criar condições para o surgimento e o incremento das vozes dos sujeitos investigados, pois já não se cai na armadilha da superioridade do saber científico (ibid.).

A análise da implicação concede ao sujeito uma visão acurada da relação com o campo, tensionando a ideia da mesma a partir da averiguação dos processos de desimplicação e sobreimplicação. O primeiro se refere ao movimento de desinteresse e desinvestimento em relação às temáticas estudadas. O segundo indica uma forma de implicação exacerbada que pode ser marcada por grande participação, mas se configurar como uma espécie de mais-valia exagerada para com o campo, ou seja, um modo que pode produzir uma certa cegueira em relação aos eventos agenciados nos espaços investigados em função da extrema imersão nesses territórios (ibid.).

O deslizar nos eixos desimplicação, implicação e sobreimplicação deve ser o foco da análise da implicação, pois os tensiona, uma vez que admitimos o caráter de positividade da implicação. Deste modo, ao compreendermos e explicitarmos a implicação, podemos melhorar a aproximação com o campo, apreender, com maior profundidade, o que nos propomos conhecer e promover cuidados éticos, além de dispor condições para problematizações, inflexões e transformações nos contextos de trabalho (ibid.).

Quando tomamos nossos aparatos teórico-metodológicos e os fenômenos sociais que nos interessamos como produzidos historicamente, e também problematizamos os nossos lugares de saber-poder e a relação que temos com os saberes e o modo como se desvaloriza outras formas de construção de conhecimento, podemos criar territórios potentes para promover alterações nas realidades.

A partir desses balizamentos da análise da implicação, discutiremos a temática do Cuidado em Saúde Mental no âmbito da Reforma Psiquiátrica. Este conceito vem ganhando força no Brasil nos últimos 10 anos, sobretudo no âmbito da saúde, e propõe transformações nas práticas, além de englobar 
olhares amplificados para os usuários dos serviços e em relação ao conceito de saúde, portando uma crítica contundente às formas tradicionais de trabalho ancoradas no objetivismo científico bem como desenhando modos inventivos de se lidar com os sujeitos e seus territórios. De acordo com Eduardo Vasconcelos (2004), um dos pilares do processo de produção de conhecimento é a pega no desejo, é o investimento afetivo em relação àquilo que nos propomos estudar. Deste modo, elencaremos alguns eventos que nos mobilizaram no trabalho como docente em Teresina - PI, algumas estórias/cenas que agenciaram afetos e reverberações ético-políticas e produziram uma relação com o campo da Reforma que tentaremos esboçar e analisar neste ensaio.

Antes das cenas e seus ecos, faz-se necessário demarcar o plano da Reforma Psiquiátrica e seu impacto no contexto nacional.

\section{Reforma Psiquiátrica e algumas questões}

Segundo Amarante (2003), a Reforma Psiquiátrica configura-se como um processo social complexo que engloba mudanças significativas nas formas de cuidado em saúde mental e no tecido sociocultural, bem como transformações jurídicas no que tange a conquista de direitos de pessoas portadoras de transtornos mentais.

Em outra produção textual, Amarante (2008) aponta que tal processo social complexo inclui quatro dimensões: teórico-conceitual, técnicoassistencial, jurídico-política e sociocultural. Segundo o autor, a partir da primeira dimensão, deve-se operar um rompimento conceitual com a construção tradicional da Psiquiatria, ancorada no positivismo, acerca da ideia de doença mental que acaba produzindo um afastamento do sujeito que por ela é acometido, encobrindo o sujeito, sua existência e suas múltiplas dimensões da vida; deste modo, na dimensão técnico-assistencial, deve-se articular a integralidade do sujeito, levando-se em consideração sua singularidade, seus contatos afetivos e redes de solidariedade, seus problemas cotidianos, seus referentes socioculturais, sua ligação com o seu território de inserção, seus desejos e projetos de vida. Nessa direção, a Reforma acaba se estabelecendo como um movimento político que visa transformações importantes em nossa sociedade, posicionando-se para além de mudanças técnicas, enfrentando a cultura manicomial e a intolerância ao diferente.

Desta forma, os serviços que desenvolvem a assistência às pessoas com transtorno mental não podem ser cristalizados e marcados por um cotidiano em que se reproduzem técnicas e protocolos de saúde; devem se ancorar numa perspectiva da inventividade e fomentar ações voltadas para seus usuários, e não para suas doenças, desenvolvendo práticas de acolhimento, de sociabilidade, de desenvolvimento de potencialidades e de produção de vida e de singularidade.

No Brasil, os Centros de Atenção Psicossocial (CAPS) têm se configurado como dispositivos importantes vinculados à Reforma Psiquiátrica e devem auxiliar, em articulação com outros serviços, como, por exemplo, a atenção básica, na substituição dos tradicionais hospitais psiquiátricos, ou seja, o conjunto desses equipamentos devem assumir o lugar, na assistência à saúde mental, de toda uma rede manicomial e a partir dos princípios éticos encampados pela Reforma.

Na prática profissional como docente no Estado do Piauí, percebemos a produção de ações que repõem a cultura manicomial e reativam processos de segregação ainda que no âmbito dos CAPS. Cenas que delineiam impasses que dificultam o avanço da Reforma, que apontam para uma certa reprodução de práticas aprisionantes e manicomiais em dispositivos que deveriam funcionar em uma perspectiva libertária, inclusiva e de reconhecimento do diferente. São cenas que aconteceram nos espaços de relação intersubjetiva entre profissionais e usuários destes serviços e que nos levaram a refletir acerca do modo como estamos trabalhando nesses locais, ou melhor, acerca do modo como estamos cuidando das pessoas que procuram essas instituições.

A seguir, descreveremos algumas dessas cenas com o intuito de apresentar como foi surgindo nosso interesse por tal temática e como as 
mesmas produziram afetações e engendraram uma relação entre nós e o campo em questão.

\section{Cenas e inquietações}

\section{CENA 01}

Uma das instituições em que trabalhamos foi convidada, por uma prefeitura de um município da Grande Teresina, para a realização de estágios em serviços de saúde e assistência social de sua rede. O CAPS era uma desses serviços e, em conjunto com outros professores, comporíamos um grupo de supervisores de estágios que lá aconteceriam.

Marcamos um primeiro encontro com alunos e com coordenadora do CAPS do município para acordarmos como o estágio seria articulado. Tal reunião aconteceu no próprio serviço, e o quadro que encontramos era desolador. A nossa ida se deu em pleno dia da semana no meio da manhã, em um horário em que a instituição deveria estar a pleno vapor, e vários eventos chamaram a nossa atenção. No CAPS não havia um usuário sequer, havia apenas um funcionário da limpeza e nos disse que as duas técnicas daquela manhã estavam chegando, e, quando as mesmas chegaram, elas estavam trajando uniformes, como marcas de diferenciação entre elas e os loucos que poderiam aparecer por ali. Percebemos também que o CAPS arquitetonicamente perfazia o modelo de instituições tradicionais de saúde, com as paredes brancas, com locais de acesso restrito e com indicações específicas para circulação de usuários nos banheiros, nos bebedouros e na cozinha.

Ficamos nos perguntando se, num dia como aquele, não poderiam estar ocorrendo oficinas das mais diversas ordens, grupos terapêuticos, assembleias, etc. Mais tarde, quando a Coordenadora chegou, como a adivinhar nosso questionamento, foi adiantando que o CAPS estava vazio daquele modo porque não era o dia de atendimento psiquiátrico: "Aqui, meu filho, só tem gente quando o médico está por aqui”. Fala que nos deu um pequeno indicativo das relações de saber-poder lá travadas.

\section{CENA 02}

Chegamos em um CAPS de maior porte em Teresina bem na hora do almoço. Mais uma vez nos chamaram atenção a questão das vestimentas, a maioria dos técnicos estava trajando jaleco; percebi que estavam usando a mesma roupa de ontem: o figurino manicomial! Mas foi o momento da alimentação dos usuários que mais nos afetou. O cardápio parecia bom: arroz, feijão, salada e bife. No entanto, os talheres à disposição não ajudavam muito para comer os pedaços de carne. Tinham apenas colheres à disposição, e com muita dificuldade cortavam a carne forçando as colheres contra os bifes ou rasgando-os com os próprios dentes. Os garfos e as facas poderiam funcionar, aos olhos dos técnicos, como armas para violências autoinfligidas ou em relação a terceiros. Vimos, em nossa frente, a materialização, a atualização da velha cultura que naturaliza loucura e periculosidade. Na hora do almoço, acredito que o que se alimentava ali era a diferença entre razão e loucura.

\section{CENA 03}

Em outro CAPS de Teresina, um usuário, militante da Reforma Psiquiátrica Piauiense e um grande artista plástico, entra em crise e quebra objetos e quadros produzidos por ele mesmo em uma atividade grupal coordenada pelos artesões do serviço. Ao invés de ser acolhido em seu episódio de sofrimento mental, ele foi expulso do CAPS pelos responsáveis pela instituição, tal como um estudante que não cumpriu as regras de uma escola e foi premiado com a expulsão como lição de moral. Os seguranças passaram a impedir a entrada do artista no CAPS por ordem da direção. Em crise, o usuário, dias depois, tentou suicídio, mas não conseguiu se matar. Mais tarde, contou com o apoio de seus amigos para procurar outro CAPS. Orientado pelos colegas de luta antimanicomial de uma ONG, procurou o Ministério Público para fazer a denúncia do que 
viveu. Os colegas de ONG não se conformavam com a situação toda e com o fato de um cidadão ser proibido de entrar em um serviço público. $\mathrm{O}$ processo ainda está caminhando...

\section{CENA 04}

Em um pequeno estudo sobre o cuidado em saúde mental realizado em um CAPS do interior, técnicos apontaram que o sucesso de uma prática de cuidado residiria no fato de o usuário aceitar tudo aquilo que a equipe teria para oferecer para ele, principalmente os medicamentos prescritos: "Aqueles que aceitam sempre ficam mais tranquilos, mais calmos" (Batista \& Lima, 2008).

\section{Poder e sujeito em Foucault}

Todas essas cenas têm em comum uma produção de sujeito que encontramos problematizada no pensamento foucaultiano. Como podemos perceber, as relações de poder são agenciadas com contundência no cotidiano desses serviços. Talvez, um exercício de aproximação dessas relações possa ajudar a desvendar o sujeito que se produz nesses contextos.

Foucault, conhecido como um estudioso do poder, em um texto intitulado Sujeito e Poder (1995), onde tenta fazer uma pequena análise de sua produção dos anos 60 e 70, procurou apontar que seu objetivo em seus estudos não foi promover uma análise do poder nem de seus eixos fundamentais. Tentou traçar uma história das redes complexas e das práticas concretas que fazem com que os seres humanos se tornem sujeitos. A constituição do sujeito é a preocupação central de Foucault nos domínios do saber, do poder e da ética: como o sujeito se insere e aparece no âmbito do conhecimento científico ("As Palavras e As Coisas"), como o sujeito aparece nas práticas divisoras e normativas ("História da Loucura", "Vigiar e Punir", "O Nascimento da Clínica") e como o sujeito se torna objeto para ele próprio ("História da Sexualidade") (Foucault, 2004; Araújo, 2008).
O estudo acerca do poder tomou grande espaço em suas produções, pois, segundo ele, as relações de poder, quando analisadas a partir das formas de resistência aos mesmos, tem a potencialidade de revelar como o poder se exerce no cotidiano de vida dos indivíduos, produz marcas que os identificam, essencializa identidades, impõe verdades que devem ser reconhecidas por todos. Logo, a compreensão do sujeito passa pela análise das relações de poder agenciadas (Foucault, 1995; Fonseca, 2007).

A abordagem do poder deve caminhar em busca mais do como se exerce o poder? do que em busca do o que é o poder?. Tal exercício permite um deslocamento crítico em direção às relações de poder e não em direção a um poder fundamental; o que pode dar acesso à complexa rede de relações de poder no cotidiano, dar acesso ao modo como tais relações se dão no âmbito das práticas humanas, nos âmbitos microssociais (Foucault, 1995).

Para Foucault, o que define uma relação de poder diz respeito a uma ação sobre a ação, a uma condução de conduta. Dessa forma, as relações de poder não se configuram no âmbito da violência, que imobiliza o outro ou o destrói. O poder necessita do outro e, ao mesmo tempo, abre um campo que permite certas reações, certas respostas e algumas criações. O poder só é exercido a partir de sujeitos livres, conduzindo suas condutas e organizando probabilidades.

O poder não é algo que se concentra ou se possui, é uma estratégia de localização, é da ordem relacional entre homens ou grupos de homens; é algo que se exerce e se apoia nos despossuídos, ao invés de desapossar. Não se encontra convergido para um ponto específico, mas encontra-se espargido, borrifado, derramado nas mais diversas relações, enfim, nas microrrelações (Foucault, 2009a; Araújo, 2008).

Foucault apontou, nesses debates, definições importantes para a palavra sujeito que auxiliam na compreensão de seus trabalhos: um sujeito a alguém a partir de ações de controle e dependência, e um sujeito aprisionado à sua própria identidade a partir de um certo autoconhecimento ou consciência. 
A partir dessas discussões, podemos perceber que o estudo do sujeito necessariamente passa pela aproximação das relações de poder travadas no cotidiano e nos mais ínfimos espaços bem como pelas formas de resistência que se insinuam em relação aos poderes que prescrevem modos de vida.

$\mathrm{Na}$ primeira cena, os próprios sujeitos se encontravam elididos do espaço que deveria articular práticas de cuidado em saúde e de proteção; nenhuma atividade estava sendo realizada e o estabelecimento estava abandonado por seus técnicos. As relações de assujeitamento se faziam perceber através dos jogos de saber-poder inscritos nas vestimentas dos técnicos, marcando o lugar da ciência e da razão em relação aos loucos, em relação ao não saber; além de reafirmar o preconceito social em relação às pessoas em sofrimento mental. Outro ponto importante, neste sentido, era a centralização das atividades do CAPS no saber psiquiátrico, que define os territórios de ação dos demais saberes e lhes atribui valoração, bem como perfazia novamente vinculações tutelares agenciadas pela Psiquiatria para com a loucura. Também é importante notar o controle da circulação dos sujeitos no CAPS através da arquitetura e das ordenações dos espaços.

Percebemos, na segunda cena, a construção de um cotidiano de serviço baseado na naturalização das relações entre loucura e periculosidade. Uma prescrição de papéis inscritos historicamente para com os loucos, um processo de criminalização da loucura. O louco seria, nesta perspectiva, um sujeito que guardaria uma potencialidade para a prática de violência (Delgado, 1992). Como consequência, na cena em questão, os usuários não tinham à disposição garfos e facas para a alimentação, o que provocou um quadro difícil de ver: os sujeitos se alimentando como animais.

Na cena três, encontramos processos impactantes de assujeitamento. Primeiramente, vemos um processo contundente de exercício de poder realizado pela direção do serviço, materializado na expulsão de um usuário de um serviço público. Depois, a articulação de uma certa violência através dos seguranças da instituição que passaram a não permitir a entrada do usuário. Além disso, percebemos uma negligência de escuta e acolhimento em um episódio de crise, o que pode indicar uma desvalorização da fala do sujeito e de seu sofrimento. Todas essas ações parecem estar ancoradas num olhar tradicional que é lançado ao louco em termos de preconceito (depreciação do discurso do sujeito louco) e periculosidade, bem como numa moralização no trato com a loucura, que os concebe como sujeitos passíveis de corrigenda, punição, admoestação, de modo que, através destas, pode-se produzir um bom sujeito, bom cidadão para a sociedade.

A última cena indica imposições e tutelas nas relações para com os usuários. Apontam para um processo de docilização dos sujeitos, que devem se submeter a tudo que a equipe de trabalho prescreve. Outro vetor importante é a medicalização das práticas em saúde mental, delineando mais uma vez as relações de saber-poder presentes no cotidiano desses serviços, uma centralidade no papel da medicina psiquiátrica e em sua tecnologia, o que acaba por reduzir a importância dos outros campos de produção de conhecimento e suprimir as vozes, saberes e modos de levar a vida construídos pelos próprios usuários e por suas comunidades.

Estes eventos, em articulação com outros acontecimentos, foram forjando nossa relação com o campo da Reforma Psiquiátrica, marcada por afetos que denotam indignação, tristeza, surpresa, estranhamento, e, ao mesmo tempo, uma vontade de luta e de mudança de quadros. Para aqueles que têm alguma trajetória na Reforma, torna-se difícil deparar-se com tais práticas e não se afetar. No entanto, precisamos desenvolver uma certa atenção para com essa relação, é necessário problematizá-la para podermos agenciar uma melhor aproximação com esses espaços institucionais e constituir uma vinculação ética em todo o processo de produção de conhecimento e/ou intervenção.

Primeiramente, devemos tensionar nossa relação com a Reforma Psiquiátrica como um todo, pois corremos o risco de tomá-la como uma perspectiva universalizante, o que acaba por desenvolver uma discussão prescritiva em relação às práticas em saúde mental que pode comprometer nossos olhares e, como consequência, não considerarmos as diferenças locais, os processos históricos de constituição dos serviços específicos bem como as estruturas contextuais para execução das políticas de saúde. 
Outro ponto importante é questionar constantemente nosso olhar acadêmico, indagando-se sobre nossa relação com o saber e com o poder que o mesmo implica. Por exemplo, nas cenas descritas, os profissionais que nos receberam, assim como nós fizemos com eles, também nos objetivaram e podem ter levado em consideração nossos lugares de docentes e de, algum modo, podem ter feito funcionar as engrenagens da relação saber-poder, o que pode ter alterado a dinâmica do cotidiano nos CAPS com a nossa presença. Além disso, nossa imersão na academia pode também instituir olhares que vão em busca de modos idealizados de proceder nesses serviços, dificultando a leitura de especificidades no cotidiano, de invenções nas formas de cuidar, bem como do papel do contexto sóciocomunitário na constituição das maneiras de funcionar dessas instituições.

No que diz respeito aos usuários, um processo de sobreimplicação com a Reforma Psiquiátrica pode promover discussões e práticas que sustentam posições das mais diversas ordens, reproduzindo tutelas sutis, vitimizações, ou debates que se apoiam em perspectivas assistencialistas. Uma das consequências mais duras desses movimentos é a despontecialização política dos usuários, o que pode entravar as transformações sociais propostas pelo Movimento Antimanicomial.

Uma sobreimplicação ainda pode dificultar a compreensão do contexto estrutural em que estão imersos os profissionais desses serviços. Uma prescrição de formas atuação ligadas à Reforma pode impedir a apreensão de vetores vitais, tais como, dificuldades financeiras dos municípios, escassez de treinamentos e capacitações, formação em saúde precária em relação à luta antimanicomial, alta rotatividade de trabalhadores, entre outros.

A partir desse esboço de nossa implicação, apresentaremos, a seguir, algumas produções teóricas acerca do cuidado em saúde mental surgidas nos últimos anos na academia com os propósitos de debater a noção de sujeito presente nas discussões elencadas e de refinar as reflexões sobre implicação com a Reforma Psiquiátrica.

\section{Derivas do cuidado em saúde mental}

Os profissionais de saúde mental se deparam com uma pluralidade de demandas no cotidiano de serviço. Em relação às demais áreas da saúde, que gozam de alguns sistemas protocolares de atuação, o âmbito em questão se caracteriza pela amplitude de necessidades e ferramentas para lidar com as problemáticas trazidas pelos usuários, requerendo ações interdisciplinares, multiprofissionais, comunitárias, além de uma produção de transversalidades. ${ }^{2}$ Dessa forma, cuidado em saúde mental implica uma concepção polissêmica bem como projetos de transformações, processualidades e invenções constantes. Embora marcado por tal extensão, refletir acerca do que vem a ser o cuidado em saúde mental e a noção de sujeito veiculada pelo mesmo se torna uma tarefa vital para todos envolvidos com a Reforma Psiquiátrica, pois indica reverberações éticas e políticas (Ballarin, Carvalho e Ferigato, 2009).

\section{Cuidado e cartografias de encontros entre os sujeitos}

Em um texto publicado em 2006, Alves e Guljor elencam premissas basilares para o cuidado em saúde mental. Primeiramente, destacam a necessidade da liberdade do usuário; operam uma crítica em relação ao isolamento instituído pelo aparato manicomial. Torna-se fundamental para o usuário o agenciamento do convívio social e de seus laços afetivos. Como consequência, investe-se no potencial do sujeito em levar sua própria vida e fazer suas escolhas, auxiliando na construção da autonomia de modo singular.

\footnotetext{
${ }^{2}$ Conceito de Felix Guattari que propõe uma transversalidade no lugar de uma verticalidade que remete na instituição aos vínculos feitos através de uma hierarquia fechada e da fixidez dos papéis descritas num organograma objetivo, um sistema de pirâmide. Uma transversalidade no lugar de uma horizontalidade que seriam as vinculações feitas entre "iguais" da mesma categoria funcional, por exemplo, que estão dentro de uma estrutura piramidal. O processo de transversalização não caminha no sentido da igualdade, mas ao contrário, prevê que o grupo comporte a diferença, o embate e até as opiniões diversas ao mesmo tempo sem que isso seja tomado como erro, dissidência política ou brigas pessoais. Sustentação do dissenso, sem que isso signifique uma dissidência. Diz respeito também aos canais de comunicação estabelecidos com os diferentes campos, saberes, grupos. Ver: Guattari (2004).
} 
Em seguida, os autores sinalizam que devemos conceber o sujeito de uma forma amplificada, ou seja, estendermos nossos olhares para além do sofrimento mental, de modo a considerar os múltiplos vetores que sustentam a vida dos usuários. Desse modo, acabamos indo ao encontro de uma história de vida, ao invés de um olhar reducionista tradicionalmente voltado para os sintomas. Nesta perspectiva, apoiar os projetos de vida se institui como dispositivo fundamental.

Outra premissa destacada é a consideração das redes onde os sujeitos se inserem, tanto para compreensão dos próprios usuários como para apreensão dos processos de crise e sofrimento psíquico. Aqui, a complexidade contrapõe-se em relação à simplificação que marca os modos tradicionais de se lidar com a loucura. Assim, as redes podem, além de fornecerem informações importantes acerca dos sujeitos, configurarem-se também como recursos para o agenciamento do cuidado.

A ideia de reparo também é questionada por Alves e Guljor (2006). Propõem que a assistência ofertada aos sujeitos deve estar ancorada no direito que têm em serem diferentes da norma. A partir desta premissa, podemos enfrentar as relações de saber-poder em que tradicionalmente se assentam as vinculações entre técnicos e usuários. Como consequência, o sujeito assistido vai construindo sua própria autonomia e exigindo uma maior amplificação das práticas do cuidado para lidar com o desenvolvimento de seus direitos e projetos de vida.

Uma das tarefas fundamentais do cuidado em saúde mental é auxiliar na construção das autonomias possíveis a partir das singularidades dos sujeitos, o que faz com que a noção de cura também seja tensionada. Cunhado pela medicina biológica, o termo cura perde potência no âmbito da Reforma Psiquiátrica porque indica uma ação que deve ser articulada sobre objetos que estão funcionando de modo errôneo com o intuito de restaurar um estado adequado.

Outro ponto importante é o respeito à singularidade dos sujeitos. As práticas em saúde mental devem partir da ideia de que para cada pessoa um projeto de cuidado. Para Alves e Guljor (ibid.), o cuidado se configura como uma atitude perene, pois leva em conta o movimento de construção singular da autonomia de cada usuário, as mudanças e as processualidades impressas nessa operação.

O papel de agenciador, incorporado pelo profissional, é a última questão destacada pelos autores. Esse papel se reflete numa atitude de responsabilização pelo usuário, questionando a neutralidade científica e a compartimentalização do indivíduo e dos saberes. Desse modo, o profissional deve se vincular afetiva e eticamente com as pessoas que buscam os serviços e agenciar seus processos de cuidado, e evitar, por exemplo, os procedimentos de encaminhamentos como simples atos de repasse para outros profissionais bem como procurar acompanhar os sujeitos em suas trajetórias nos serviços e no movimento de cuidado como um todo.

\section{Cuidado, ética e rupturas epistemológicas}

Em uma produção que se propõe refletir acerca do papel do CAPS como produtor de cuidado e espaço privilegiado de encontros, Silvio Yasui (2007) promove debates sobre o cuidado em saúde mental e enumera alguns pontos de ancoragem que auxiliam na compreensão do conceito e de seu desenvolvimento. O autor aponta que a ação de cuidar se constitui como a essência do trabalho em saúde mental na Reforma Psiquiátrica, pois a mesma propõe novos modos de lidar com a loucura a partir de uma crítica contundente à racionalidade médica biologizante. Para tanto, o cuidado deve estar mais voltado para a invenção de uma vida social ética e potente do que preocupado com uma cientificidade tradicional.

Yasui (ibid.) ainda ressalta que o cuidado está para além do âmbito da saúde, configurando-se como uma atividade central na vida humana, sendo o encontro o lócus privilegiado de sua efetivação. O espaço das relações entre os sujeitos é onde se dá a produção do cuidado, onde surgem reflexões éticas em função da vinculação que estabelecemos com os outros. Desse modo, "o cuidado é uma condição que possibilita, produz, mantém, preserva a vida humana, que é frágil e fugaz” (Yasui, 2007, p.161). 
Nas práticas em saúde mental, o cuidado não deve ser concebido apenas como uma reprodução ou mera execução de técnicas para tratar uma problemática que se encontra no sujeito. Cuidar nos remete a relações com os outros, que envolvem comprometimento e implicação nos espaços de encontro.

Um olhar amplificado também se sobressai no pensamento de Yasui (ibid.). A compreensão do sujeito deve englobar as múltiplas dimensões da vida dos usuários, histórias de vida, contextos sociais, culturais e econômicos. Os procedimentos de cuidado devem estar para além do quadro apresentado como problemático, os diversos âmbitos de vida devem ser articulados tanto na compreensão das questões trazidas como nas possíveis formas de solução.

O reconhecimento da singularidade e do lugar social dos usuários também é condição fundamental para as relações de cuidado. Isso implica em um rompimento epistemológico com saberes e práticas tradicionais, pois não lidaremos mais com objetos de estudo ou intervenção, mas sim com um sujeito e toda a dinâmica de sua vida e do seu existir. Cuidar, nessa direção, significa estar em um processo relacional de constante invenção, construção, costura, montagem, de projetos de vida singulares; é agenciar e articular um espaço intersubjetivo. Desse modo, conseguiremos enfrentar os modelos hegemônicos que se concentram unicamente nos fenômenos patológicos e nas ações prescritivas (ibid.).

\section{Loucura, cuidado, resistência e transformação}

Antonio Lancetti (2010), em um texto em que avalia as ações de Serviços Residenciais Terapêuticos (SRT's) e o trabalho de agentes de saúde e enfermeiros que trabalham na Cracolândia, ambos no município de São Paulo-SP, propõe que as práticas de cuidado se constituem como eixo fundamental nessas instituições de saúde mental e que guardam a potencialidade de produzir transformações subjetivas tanto nos usuários como nos profissionais.
Lancetti (ibid.), baseado na Filosofia de Heidegger, indica que o espaço de encontro e das relações intersubjetivas compõe o âmbito de atuação do cuidado. O cuidado seria a força motriz de composição do sujeito na arte do encontro. No entanto, também aponta, assim como os autores acima, que é necessária a articulação de uma pluralidade de campos para o agenciamento do cuidado e para a construção do sujeito, tais como, direito, artes, produção de renda e trabalho, cultura, apoio sóciocomunitário. Dessa maneira, o cuidado pode ser propulsor de novos modos de vida e de invenção de si. Segundo o autor, o cuidado funciona como princípio de resistência e sustentação ética para todos os trabalhadores, principalmente para aqueles que trabalham com sujeitos que não se encaixam e desafiam os padrões tradicionais da saúde como um todo, como as pessoas que estiveram por um longo período internadas em manicômio e as que são usuárias de crack, campos analisados por ele no artigo.

\section{Cuidado, movimento e invenções}

Ayres (2009), apoiado em Kant e Heidegger, propõe que os espaços de saúde se constituem como locais de encontro onde a busca pela resolutividade dos problemas de saúde deve ser acompanhada de uma noção de sujeito ancorada na intersubjetividade, indicando que a construção de si passa pela relação, e tal relação nos põe diante do outro em uma perspectiva desejante e na tarefa de construção de modos de vida que sustentem a nossa existência em um mundo compartilhado. Assim, como desdobramento desses encontros, a busca pelo sucesso no campo da saúde não se restringe a um êxito técnico, mas envolve a inventividade da saúde, a busca pela promoção da saúde, não como um estado homeostático, mas como uma relação em busca da concretização de projetos de vida em intersubjetividade.

Desse modo, nos âmbitos de assistência à saúde, torna-se tarefa vital do cuidado o movimento de consideração e construção de projetos de vida num palco onde o sujeito que cuidamos não seja compreendido como unidade estanque e permanente; tal encontro já revela o desejo de mudança em busca de transformações de quadros. Assim, a tarefa de cuidar se afasta 
das proposições de cura, tratamento e controle, o que proporciona uma abertura para a invenção da saúde e da vida (Ayres, 2009).

Em outra produção textual, Ayres (2005) aponta que o cuidado se aporta numa relação de encontro que deve ser pautada pelos seguintes aspectos: movimento; interação; identidade e alteridade; plasticidade; projeto; desejo; temporalidade; não causalidade; responsabilidade. Tais aspectos indicam outra frequência de cuidado, para além da reprodução tecnocientífica, delineando o fomento de relações baseadas na ética, na inventividade, na horizontalidade e na implicação afetiva em relação a quem se cuida.

\section{Cuidado e pluralidade}

Ballarin, Carvalho e Ferigato (2009), em um trabalho de resgate de produções brasileiras sobre o cuidado em saúde mental, distinguiram três eixos temáticos de sentidos para o cuidar, estando os mesmos entrelaçados, a saber: perspectiva ética e filosófica; a dimensão técnica e instrumental do cuidar em saúde mental; a dimensão política do cuidado.

No primeiro eixo, os autores ressaltaram a importância dos encontros entre os sujeitos, sendo o cuidado a linha principal dessas relações e constitutivo da condição humana, o que reverbera, em termos éticos, no reconhecimento das singularidades dos sujeitos em sofrimento mental e no questionamento das relações assimétricas que marcavam as práticas tradicionais. O segundo eixo revela que as práticas de cuidado devem ser pautadas em encontros intersubjetivos que primam por relações horizontalizadas, que podem ser materializadas através dos diálogos, da escuta acolhedora, da responsabilização de profissionais e usuários e no comprometimento político com as mudanças sociais e culturais. Por fim, o aspecto político do cuidado se sustenta a partir dos processos de emancipação dos usuários, ancora-se no apoio a construção das autonomias; além disso, indicaram que as ações do cuidar estão para além do aspecto técnico-científico, elas implicam engajamento e transformações de quadros de relação de poder, articulam e questionam uma pluralidade de campos necessários para o cuidado dos sujeitos envolvidos (ibid.).

Todas as produções textuais elencadas delineiam que a compreensão da noção de sujeito, presente nas discussões acerca do cuidado, deve passar pela consideração das múltiplas dimensões que envolvem a vida, sejam elas sociais, culturais, econômicas, familiares, de trabalho, redes afetivas de amizade e solidariedade. Todos os autores propõem uma visão de sujeito assentada numa perspectiva política de transformação e autonomia; elegem o encontro como âmbito fundamental para a constituição dos sujeitos.

As reflexões éticas propostas esboçam apontamentos que devem direcionar os caminhos das relações entre os sujeitos. Primeiramente, quando questionam os lugares de exercício de poder das práticas tradicionais de saúde e sugerem vinculações mais simétricas e, ao mesmo tempo, com respeito, reconhecimento e sem o apagamento das diferenças e singularidades. Cartografam também uma noção de sujeito que se pauta no movimento e na ação, ou seja, um sujeito capaz de agir politicamente nos mais diferentes campos e transformar realidades. Com efeito, o sujeito não é concebido como unidade estanque ou cristalizada, mas marcada por processualidade e com potencial de alteridade de seus modos de vida.

Acreditamos que essas problematizações são importantes porque ajudam a pensar o avanço das políticas públicas no cotidiano dos serviços e questionam, em termos éticos, as produções das mesmas acerca de seus impactos sociais e comprometimento político. Em especial, para o campo da Reforma Psiquiátrica, que se propõe como movimento político e social para além das mudanças técnicas, debates desta natureza devem ser uma constante e uma necessidade. A multiplicidade de vozes que encontramos acerca do sujeito nas produções acima se aproxima dos interesses da Reforma, pois reafirmam as diretrizes encampadas por ela e recolocam frequentemente velhas e boas questões: que sociedade queremos construir? Quais sujeitos estamos auxiliando a produzir? 
A seguir, debateremos mais um núcleo importante no pensamento de Michel Foucault, a saber: o cuidado de si. Esta ideia é fundamental para a história da construção da noção de sujeito no Ocidente bem como pode, talvez, fornecer reflexões para o âmbito das práticas de saúde.

\section{Cuidado de si}

Outra produção foucaultiana acerca da ideia de sujeito que pode auxiliar na aproximação com o campo da saúde mental é a noção de cuidado de si. Foucault trabalha, principalmente, esta noção no livro História da Sexualidade III e no curso de 1982, a Hermenêutica do Sujeito. Neles, Foucault procura escrever uma história acerca da noção de sujeito distinta do projeto articulado nos anos 70, no qual analisa a constituição do sujeito a partir da sujeição às máquinas de poder.

Para tanto, Foucault se debruça sobre as práticas de si, interessa-lhe escrever a história dos modos pelos quais o homem articula a relação de si para consigo, a "história do olhar a partir do qual eu me constituo para mim mesmo como sujeito" (Gros, 2008, p.128).

A compreensão do sujeito a partir das técnicas de si implica uma noção de sujeito que inclui a transformação, a ideia de um sujeito que pode se construir, que se produz através de exercícios, que oferece para si mesmo modos de existir e de se conduzir, que pode inventar modos de andar a vida (ibid.).

Em A Hermenêutica do Sujeito, Foucault (2010) indicou que a história do Cuidado de Si perfaz mil anos e destacou três momentos importantes: o momento socrático (séc. V a.C.); a idade de ouro do cuidado de si mesmo (sécs. I-II) e a passagem do ascetismo pagão ao ascetismo cristão (sécs. IV-V). A visita que Foucault faz aos antigos não se deu com a intenção de fornecer respostas para as problemáticas contemporâneas, mas com o intuito de apresentar que as relações entre o sujeito e os jogos de verdade se configuram como produções históricas e que diferentes desenhos dessas relações ganharam consistências diversas ao longo do tempo (Mattar \& Rodrigues, 2011).

A Filosofia era concebida, para os antigos, mais como uma arte de viver do que como um processo de conhecimento, o que delineia uma relação diferente entre o sujeito e a verdade. Uma série de práticas de si para si, o que Foucault chama de exercícios espirituais, é agenciada para que o sujeito possa se autoconstituir e se autogovernar. "A filosofia era então uma preparação para a vida, um modo refletido de exercer a liberdade, ou seja, uma ética" (2011, p.15). A liberdade estava relacionada com o cuidado de si, com o domínio de si, a partir de exercícios para com os apetites, excitações e exaltações que poderiam aprisionar o sujeito.

Ao perfazer os caminhos históricos da relação entre sujeito e verdade, Foucault propôs uma revisão da fórmula fundadora dessa relação na tradição filosófica ocidental, a saber: o conhece-te a ti mesmo (gnôuthi seautón). Foucault resgata a noção de epiméleia heautou ou o cuidado de si mesmo e mostra, a partir da análise dos textos antigos, como o preceito délfico gnôuthi seautón, enfatizado principalmente por Sócrates e Platão, emerge entrelaçado ao cuida de ti mesmo e, muitas vezes, em relação de subordinação (Foucault, 2010; Mattar \& Rodrigues, 2011).

O cuidado de si perdurou como um verdadeiro fenômeno cultural, extrapolando até mesmo o campo filosófico, ao longo das culturas grega, helenística e romana; constituiu-se como uma linha básica a ser seguida por aqueles que queriam ter uma vida ativa embasada em uma racionalidade moral. Ao demonstrar tal alcance, Foucault destacou a noção de epiméleia heautou para além de uma história das representações ou de uma história das noções ou teorias (embora tenha contribuído para ambas), e a configurou como uma ancoragem vital para a história dos processos subjetivos e de constituição do sujeito (Foucault, 2010).

A noção de cuidado de si envolve uma forma de agir em relação a si mesmo, aos outros e ao mundo; imprime uma nova direção ao olhar: da exterioridade para a interioridade; articula uma série de atitudes de si para si 
nas quais o sujeito procura apropriar-se de si mesmo, depurar-se, movimentar-se, mobilizar-se, converter-se, enfim, transformar-se, a partir de práticas e exercícios que podem concentrar a meditação, o exame de consciência, dietas, fixação das memórias pretéritas, etc. (ibid.)

Com os gregos, a partir da análise do Diálogo entre Sócrates e Alcebíades, Foucault buscou desenvolver a noção de cuidado de si a partir da necessidade política para os jovens que iriam exercer alguma forma de poder perante a cidade. A intenção socrática era discutir com Alcebíades: Qual o eu que se deve ocupar-se para se ocupar com os outros como convém? Uma circularidade entre: o objeto que se deve cuidar e o saber governar.

Foucault destacou como o cuidado de si, na Filosofia helenística e romana, abrange mais um campo vasto de práticas do que algo que se funda no conhecimento; não se restringe a pessoas que exercerão algum tipo de função de governo em relação a polis e se torna um imperativo para todos.

Um ponto vital é que o cuidado de si não se constitui como uma atividade solitária. No cuidado de si é preciso chamar um outro para nos ajudar a cuidar de nós mesmos, donde surge a figura do mestre, que articula atividades sociais de diálogos, de ensinamentos, de aprendizagens etc.

Além disso, o cuidado de si implica a relação com os outros, ações políticas. Segundo Foucault, o cuidado de si produz uma certa distância entre o sujeito e o mundo. No entanto, esta distância é que possibilita uma ação como convém e a fomenta em seu potencial transformador, impedindo uma reação precipitada perante o mundo (Gros, 2008).

Foucault (2009b), no entanto, demonstrou como a noção de cuidado de si foi sendo requalificada e perdeu força ao longo do tempo, em especial na era moderna. Apesar da distância em relação ao preceito socrático, o autor apontou o que ele chamou de momento cartesiano, entre os séculos XVI e XVII, como evento que marcou a desconsideração do cuidado de si como regulador da relação entre sujeito e verdade. Em linhas gerais, o acesso à verdade não se dará mais a partir dos exercícios espirituais, das transformações vividas pelas práticas dos sujeitos, e vai se dar como um ato de conhecimento, através de artifícios no interior do próprio ato conhecimento que visam neutralidade, objetividade e um sujeito a ser elidido. Desse modo, "A verdade não precisa mais ser vivida, apenas investigada e dialogada” (Mattar \& Rodrigues, p.23, 2011).

Como assinalado anteriormente, o resgate da noção de cuidado de si não se deu com a intenção de uma replicação de suas práticas na atualidade, mas com o objetivo de mostrar que as questões acerca do sujeito, da verdade e dos processos subjetivos se configuravam de forma diferente e assinalavam um processo ético de produção de si e do mundo. Através de tal analítica, Foucault apontou para o potencial de invenção, de estetização da vida e de transformação da realidade a partir da vivência da liberdade em articulação com o cuidado de si (Veyne, 2004). Acreditamos que existe aí um convite para podermos pensar a constituição da realidade de uma maneira diferente; em uma entrevista no ano de 1983, Foucault, influenciado pelo pensamento de Nietzsche, perguntava-se porque a nossa vida não pode ser uma obra de arte, uma criação, uma invenção, do mesmo modo como pensamos a arte somente relacionada aos objetos (Foucault, 1995). Nesse sentido, talvez possamos pensar novos processos subjetivos e novos modos de instituição da realidade social, bem como, quem sabe, repensar nossas práticas em saúde mental.

MAIS UMA CENA

Quem veio primeiro?

O ovo ou a galinha?

Se tiver sido a galinha quem botou o ovo?

Que dilema

Será que vieram os dois juntinhos?

Quem veio primeiro?

O amor ou a dor?

Se tiver sido o amor,

Como existiria dor de um apaixonado?

Que dilema

Será que vieram os dois juntinhos? ${ }^{3}$

${ }^{3}$ Poesia de autoria de usuários da rede substitutiva de saúde mental do Piauí. 
Uma Organização Não Governamental de Teresina-PI com o apoio do Ministério da Cultura, através do Concurso Público Prêmio Cultural Loucos pela Diversidade, realizou um trabalho com usuários da rede substitutiva de saúde mental de três municípios piauienses: Teresina, União e Água Branca. De maneira geral, a proposta do Ministério consistia em promover, por meio da cultura, a emancipação, a visibilidade e a sociabilidade de sujeitos em sofrimento mental.

Oficinas de poesia fizeram parte da proposta da atividade nesses três municípios, e contaram com a participação de 50 usuários aproximadamente. Em uma série de encontros entre usuários, oficineiros e trabalhadores, foram produzidas várias poesias. Em todo o processo, o centro das preocupações não foram parâmetros estéticos ou as diretrizes formais da língua portuguesa, o foco foi a vida dos participantes, seus afetos, suas ideias e seus anseios, em articulação com as produções textuais.

Muitas das poesias, a maioria de autoria dos usuários, foram compiladas para a publicação de um livro intitulado Recados da Alma (o qual acompanhamos o lançamento). $\mathrm{O}$ evento aconteceu em um grande teatro de Teresina-PI e foi marcado pela declamação das poesias por seus próprios autores bem como pelas falas que desenhavam os efeitos de todo o trabalho, que indicavam como o exercício da escrita pôde suscitar questões acerca de suas existências e reverberações em relação às suas próprias condições. Longe de ser pensado como um modelo ou como uma técnica a ser reproduzida, o trabalho relatado na cena em questão pode indicar caminhos para a invenção de cotidianos de serviços; refletir acerca de como práticas dessa ordem podem ajudar na potencialização de espaços de criação da vida e, talvez, aproximar-se da questão de Foucault (1995) em relação ao sujeito: “(...) não poderia a vida de todos se transformar numa obra de arte? Por que deveria uma lâmpada ou uma casa ser um objeto de arte, e não a nossa vida?" (p.261).

\section{Referências bibliográficas}

Amarante, P. (Coord.). (2003). Saúde mental: políticas e instituições. Rio de Janeiro: Fiotec/Fiocruz, EAD/Fiocruz.

(2008). Saúde Mental e Atenção Psicossocial. $2^{\mathrm{a}}$ ed. Rio de Janeiro: Editora Fiocruz.

Araújo, I. L. (2008). Foucault e a Crítica do Sujeito. $2^{\mathrm{a}}$ ed. Curitiba: Editora UFPR.

Ayres, J. R. (2005). Cuidado e Reconstrução das Práticas de Saúde. In: Minayo, M. C.; Coimbra Jr, C. (Orgs.). Críticas e Atuantes: Ciências Sociais e Humanas em Saúde na América Latina. $1^{\text {a }}$ ed. Rio de Janeiro: Editora Fiocruz.

(2009). Cuidado: Trabalho e Interação nas Práticas de Saúde. $1^{\mathrm{a}}$ ed. Cepesc: UERJ/IMS: Abrasco.

Ballarin, M. L.; Carvalho, F. \& Ferigato, S. (2009) Os Diferentes Sentidos do Cuidado: Considerações Sobre a Atenção em Saúde Mental. $O$ Mundo da Saúde, São Paulo, v. 33, n. 2, 2009, p. 218-224.

Batista, R. D. \& Lima, E. (2008). Práticas de Cuidado em Saúde Mental: Um Estudo Realizado no CAPS II do Município de Floriano-PI. IN: Anais do XVIII Congresso de Epidemiologia. Porto Alegre: Meio Magnético.

Delgado, P. G. (1992). As Razões da Tutela. Rio de Janeiro: Editora Te Corá.

Gros, F. (2008). O Cuidado de Si em Michel Foucault (p. 127-138). In: Rago, M. \& Veiga-Neto, A. (Orgs.). Figuras de Foucault. Belo Horizonte: Autêntica.

Fonseca, M. A. (2007). Michel Foucault e a Constituição do Sujeito. São Paulo: Educ. 
Foucault, M. (1995). O Sujeito e o Poder (p. 231-249). In: Dreyfus, H. \& Rabinow, P. Foucault, Uma Trajetória Filosófica: Para Além do Estruturalismo. Rio de Janeiro: Forense Universitária.

(2004). In: Ditos e Escritos V: Ética, Sexualidade, Política (p. 234239). Rio de Janeiro: Forense Universitária.

(2009a). Vigiar e Punir. 36 a ed. Petrópolis: Vozes.

(2009b). História da Sexualidade III: O Cuidado de Si. 10ª reimp. São Paulo: Graal.

(2010). A Hermenêutica do Sujeito. $3^{\mathrm{a}}$ ed. São Paulo: Martins Fontes.

Guattari, F. (2004). Psicanálise e Transversalidade: Ensaios de Análise Institucional. Aparecida - SP: Ideias e Letras.

Lancetti, A. (2010). Cuidado e Território no Trabalho Afetivo. Cadernos de Subjetividade, São Paulo, p. 90 - 97.

Lourau, R. (2004). Implicação e Sobreimplicação; Implicação Um Novo Paradigama?; Implicação-Transdução. In: Altoé, S. (org.). René Lourau: Um Analista Institucional em Tempo Integral. São Paulo: Hucitec.

Mattar, C. \& Rodrigues, H. (2011). O Cuidado de Si como Prática da Liberdade: Contribuições para uma Discussão sobre a Ética em Michel Foucault (p. 15-32). In: Lopes, K. J. M.; Carvalho, E. N.; Matos, K. S. A. L. Ética e as Reverberações do Fazer. Fortaleza: Edições UFC.

Vasconcelos, E. M. (2002). Complexidade e Pesquisa Interdisciplinar: Epistemologia e Metodologia Operativa. $2^{\mathrm{a}}$ ed. Petrópolis, RJ: Vozes.

Veyne, P. (2004). Un Arqueólogo Escéptico (p. 23-87). In: Eribon, D. El Infrecuentable Michel Foucault: Renovación del Pensamiento Crítico. São Paulo: Letra Viva.
Yasui, S. (2007). CAPS: Estratégia de Produção de Cuidado e de Bons Encontros. In: Pinheiro, R. et al. (Orgs.). Desinstitucionalização da Saúde Mental: Contribuições para Estudos Avaliativos. $1^{\mathrm{a}}$ ed. Rio de Janeiro: Cepesc/UERJ, Abrasco. 


\section{A questão do reconhecimento: \\ Axel Honneth e a atualização do modelo conceitual hegeliano a partir da Psicologia Social de George Herbert Mead}

\author{
Sheila Ferreira Miranda ${ }^{1}$
}

A

questão do reconhecimento social aparece de maneira significativa nas sociedades contemporâneas, a partir da constituição de um novo modelo de relações sociais (Paiva apud Mattos, 2006). Este modelo, calcado em modificações históricas, sociais e econômicas denunciou a transição de uma unidade sincrônica ${ }^{2}$ das posições de sujeito previsivelmente ocupadas pelos agentes sociais, para uma completa indeterminação das posições ocupadas pelos mesmos, causando um verdadeiro colapso nas teorias tradicionais das Ciências Sociais (Laclau, 1986).

Esta pluralidade do social (Laclau, 1986) permitiu que as novas relações estabelecidas, não mais calcadas em hierarquizações estáticas, possibilitassem a emergência de segmentos até então invisibilizados, que passaram a se organizar e reivindicar seus direitos (Mattos, 2006).

A politização das minorias emerge com vigor a partir da segunda metade do século XX (Mattos, 2006), de maneira que as demandas por direitos sociais ocorrem a partir de reivindicações que compreendem tanto a ideia de igualdade de direitos (por exemplo, o sufrágio universal),

\footnotetext{
${ }^{1}$ Bolsista pela Coordenação de Aperfeiçoamento de Pessoal de Nível Superior (CAPES).

${ }^{2}$ Segundo Laclau (1986), a identidade dos agentes sociais não é mais concebida como constituída num único nível da sociedade. "Torna-se cada vez mais impossível identificar o grupo, concebido como referente, como um sistema ordenado e coerente de posições de sujeitos" (p. 41), de forma que as categorias tradicionais - por exemplo, as de classe - são insuficientes para a realização de uma leitura da identidade global dos sujeitos. A posição dos indivíduos no sistema produtivo, por exemplo, não mais determina sua localização nos demais sistemas (político e social)
}

quanto às lutas pelo direito à diferença, a partir do reconhecimento de identidades coletivas específicas (movimentos gays, movimentos negros, movimentos feministas).

As conceituações das teorias tradicionais acerca da ideia de conflito perderam o sentido diante da reconfiguração da realidade, de maneira que a emergência dos novos movimentos sociais (Laclau, 1986) trouxe à tona a necessidade da construção de novos alicerces teóricos.

Neste contexto, a categoria neo-hegeliana do reconhecimento social emerge através de diversos autores ${ }^{3}$ e vem tomando importância crucial nos debates contemporâneos, trazendo novas perspectivas teóricas para reflexão sobre os problemas das sociedades democráticas.

Axel Honneth, dissidente da vertente intelectual denominada Teoria Crítica da Sociedade, pode ser localizado como um dos principais autores da atualidade que contribuem para a reatualização da perspectiva hegeliana. $\mathrm{O}$ autor, fazendo uma crítica à teoria dual elaborada por Habermas, defende que a análise da intersubjetividade comunicativa deve partir dos conflitos, para que seja superado o déficit sociológico cometido pelo seu antecessor. ${ }^{4}$

Baseado na leitura Habermasiana, nos textos do jovem $\mathrm{Hegel}^{5}$ e na conceituação pós-metafísica de Mead; Honneth irá tecer sua tese

${ }^{3}$ De acordo com Mattos (2006, p. 15-16), "os principais autores que procuram re-trabalhar essa honorável herança hegeliana são: o filósofo político canadense Charles Taylor, o filósofo social e sociólogo alemão Axel Honneth e a cientista política americana Nancy Fraser".

${ }^{4}$ Neste contexto, Honneth (2003) critica o choque de racionalidades (sistema e mundo da vida) estruturantes na teoria habermasiana, pelo fato de resultar em uma concepção de sociedade agonística, sem levar em conta a importância do conflito como mediador essencial na leitura das trajetórias que visam à emancipação.

${ }^{5}$ Refiro-me ao período dos escritos juvenis de Jena (1801/1806) ou trabalhos da juventude de Jena. Este momento de sua obra diz respeito a uma ocasião na qual o autor acata a importância da subjetividade e desenvolve a noção de reconhecimento em seus textos, partindo do principio de liberdade individual. Assim, a noção de reconhecimento aparece - e irá desempenhar um papel crucial em toda sua filosofia - pois para o autor, no Estado, o reconhecimento político de que todos são pessoas e cidadãos pode ser efetivamente assegurado de forma que, reconhecerse nas instituições dadas, significa para Hegel, considerar a autonomia e liberdade do sujeitopressuposto necessário para a realização do indivíduo (Ramos,2002). 
buscando ancorar-se na proposta original de uma teoria crítica vislumbrada por Horkheimer.

A noção de crítica remonta ao imperativo de apreensão da realidade a partir da história humana, buscando compreender o funcionamento da sociedade à luz de uma orientação emancipatória, e não através de conceitos teóricos que busquem apenas descrever as relações sociais vigentes de maneira parcial - modelo geralmente desenvolvido pelos teóricos tradicionais (Nobre apud Honneth, 2003).

Segundo esta linha de pensamento, a orientação para a emancipação permite uma compreensão mais ampla da sociedade, de forma

que a teoria esteja ancorada na realidade como parte dela, e, justamente por isso, seja capaz de mostrar quais são os elementos não desenvolvidos do real que permitem perceber o horizonte de sua superação através da crítica (Souza, 2009).

Por esta razão, Honneth (2003) parte de elementos teóricos não desenvolvidos por seus antecessores, para formular uma tentativa de atualização das ideias propostas pelos mesmos, buscando renovar as potencialidades da teoria crítica, a partir de uma tese que contempla a leitura dos conflitos sociais, feita através de uma clave comunicativa. ${ }^{6}$

Esta teorização está ancorada na forma como o autor compreende a sociedade: como um processo intersubjetivo de luta por reconhecimento, que apresenta como núcleo estrutural as intermináveis disputas por aceitação de diferentes pretensões identitárias. Estas envolvem tanto características individuais, contextualmente específicas, quanto o respeito solidário, institucionalizado através das normas do direito positivo. Um processo de lutas que pode resultar tanto na reelaboração de significados e práticas identitárias (individuais e/ou coletivas), quanto na reestruturação

\footnotetext{
${ }^{6}$ As contribuições deixadas pela "Teoria da Ação Comunicativa" habermasiana, aparecem como um dos eixos principais para a leitura dos conflitos sociais na luta pelo reconhecimento, pois a ideia de que a estrutura de dominação pode ser explicada como resultado de um processo comunicativo danificado leva Honneth a calcar sua elaboração teórica sobre o imperativo de um entendimento intersubjetivo para a integração social (Souza, 2009).
}

moral das sociedades. "Desse modo, Honneth preferirá partir dos conflitos e de suas configurações sociais e institucionais para, a partir daí, buscar suas lógicas" (Nobre apud Honneth, 2003, p.16). Vejamos como esta elaboração teórica é conduzida em sua tese a partir da etapa de apropriação da leitura da Psicologia Social de Mead.

\section{De Hegel a Mead: o entrelaçamento de ideias}

De acordo com Honneth (2003) e Habermas (2002), George Herbert Mead foi o primeiro autor a desenvolver uma teoria que contemplasse a importância da experiência intersubjetiva na formação das identidades, abandonando as premissas metafísicas de discussão da subjetividade.

O entrelaçamento das ideias de Hegel e Mead permitiu a edificação de uma Teoria Crítica que colocou em primeiro plano a ideia de conflito, na medida em que ambos os autores coincidem em dois aspectos centrais da tese defendida por Honneth (2003):

a) consideram a luta pelo reconhecimento como ponto referencial de uma construção teórica que elucide a evolução moral das sociedades;

b) concordam que a identidade está atrelada à experiência do reconhecimento intersubjetivo.

A intuição do reconhecimento intersubjetivo elaborada pelo primeiro autor é coincidentemente comprovada de maneira empírica pelo segundo, de forma que a construção teórica de Honneth (2003) toma contornos pósmetafísicos, a partir do trabalho de uma reatualização da obra hegeliana que assume formas sociológicas no contexto pragmatista (Farr, 2008) das produções de Mead.

\footnotetext{
${ }^{7}$ Tais premissas eram baseadas fundamentalmente numa herança teórica que conduzia à ideia de introspecção como unidade formadora da consciência. Assim, a precedência da reflexão isolada frente à matéria garantiria a unidade e essência da subjetividade humana (Habermas, 2002).
} 
Tal ideia é construída na Filosofia hegeliana da seguinte forma: o sujeito só consegue se conhecer através da realização objetiva das próprias intenções (que ocorre necessariamente através das relações intersubjetivas) e, portanto, pelo abandono de uma dimensão puramente cognitiva para assumir um estado de conhecimento prático de si mesmo (Honneth, 2003).

De acordo com Honneth (2003), Mead reitera esta discussão, comprovando empiricamente a teoria de Hegel ao discutir o significado do psíquico, através de um exame epistemológico do objeto da Psicologia.

Debatendo a postura acrítica das construções teóricas vigentes da disciplina, Mead (1991) conclui que a Psicologia se manteve, a partir de Descartes, entre fronteiras ambíguas que acarretaram problemas epistemológicos evidentes.

Como ciência natural e empírica, sua tendência remetia a uma leitura do psíquico a partir de uma concepção de consciência como algo meramente dado, partindo de uma visão de mundo que considerava os objetos externos estáticos e inquestionáveis, diante dos quais eram testadas ou refutadas suas hipóteses experimentais (Mead, 1991).

Assim, em lugar de dedicar-se a esclarecer as fronteiras do seu objeto - o psíquico - Mead (1991) conclui que a Psicologia, naquele contexto, estava transferindo seu interesse às condutas meramente externas, buscando o imperativo do reconhecimento como ciência:

A psicologia, no entanto, não se interessou por estes enigmas epistemológicos e metafísicos [...] Seu interesse mudou para os processos, ali onde o fenomenismo é inofensivo, aparecendo como psicologia fisiológica, como psicologia funcional, como psicologia dinâmica e ignorou os problemas que não the importavam (Mead, 1991, p.167). ${ }^{8}$

\footnotetext{
${ }^{8}$ Tradução nossa: "La psicología, sin embargo, no ha estado interesada en estos enigmas epistemológicos y metafísicos [...]. Ha desplazado su interes hacia los procesos, allí donde el fenomenalismo es más inofensivo, apareciendo como psicología fisiológica, como psicología funcional, como psicologia dinámica, y ha ignorado problemas que le tienen sin cuidado".
}

Tentando superar tais problemas epistemológicos, Mead (1991) propõe uma visão interacionista destes processos, sugerindo que a consciência da subjetividade (autoconsciência) só se constitui a partir da pressão gerada pelo surgimento de um problema prático em situações sociais, a partir do qual o sujeito é impelido a reagir. E para que este processo interativo seja bem-sucedido, ele deve alcançar tal nível de consciência que o permita compreender o significado social de suas próprias práticas, para estar em condições de prever e controlar os comportamentos dos demais (Honneth, 2003).

Partindo destas premissas, podemos então inferir que a compreensão dos mecanismos subjetivos assume implicações diretas ao entendimento da realidade social. De tal modo que surge uma questão de fundamental importância a ser respondida pela Psicologia Social: a descrição do mecanismo através do qual é gerada a consciência do significado intersubjetivo assumido pelas ações dos sujeitos (Honneth, 2003). Mead então irá se dedicar a este trabalho (Mattos, 2006), tomando como ponto de partida algumas inferências sobre as condições de surgimento da autoconsciência humana.

\section{Do self ao reconhecimento intersubjetivo}

Para Mead (1991), o que nos diferencia dos animais é a constituição do self. O self é uma estrutura eminentemente social (e não inata), que surge a partir de experiências ${ }^{9}$ de integração do indivíduo à realidade das interações humanas. Assim, o self constitui a dimensão da personalidade composta pela consciência que o indivíduo tem de si mesmo (autoconsciência).

Esta última edifica-se a partir da incorporação das atividades sociais, possibilitando a socialização dos indivíduos a partir da compreensão acerca dos símbolos compartilhados e a consequente reprodução de gestos e

\footnotetext{
${ }^{9}$ Mead (1991) demarca que o termo experiência diz respeito às condutas ou comportamentos dos indivíduos, e não aos diferentes estados subjetivos de consciência, diante de uma reflexão isolada e puramente introspectiva.
} 
valores comuns. Além disto, o desenvolvimento da autoconsciência também possibilita a reflexão sobre os próprios atos e os determinantes sociais, gerando a autonomização das ações (individuação) (Habermas, 2002).

Em Mead, a constituição da autoconsciência está intimamente ligada ao desenvolvimento da consciência dos significados sociais (Honneth, 2003), de forma que o individuo só atinge um self, quando é capaz de responder aos atos sociais ${ }^{10}$ e ver a si mesmo a partir da perspectiva dos outros (Mead, 1991).

E a explicação para estes processos está no desenvolvimento teórico da "eticidade intersubjetiva" (Mattos, 2006), a partir dos conceitos de Eu, Mim e Outro Generalizado desenvolvidos por Mead (1973, 1991).

Segundo este mesmo autor, o Eu e o Mim apresentam-se como componentes indissociáveis do self.

O Mim representa a dimensão da incorporação e internalização das regras institucionalizadas, traduzindo a presença do outro na consciência do indivíduo. Reflete $\mathrm{o}$ grupo de atitudes adaptativas organizadas e generalizadas, tendo como referencial as convenções sociais. O Mim confere ao sujeito "sua posição, lhe concede a dignidade de ser um membro da comunidade, constitui a fonte de sua reação emocional aos valores que pertencem a um membro da comunidade. É a base de sua incorporação à experiência de outros" (Mead, 1973, p.224). ${ }^{11}$

\footnotetext{
${ }^{10}$ Segundo Mead (1991, p.175, tradução nossa), quando falamos em ato social, nos referimos a uma "[...] classe de atos que implica na cooperação de mais de um indivíduo, e cujo objeto, tal como aparece definido pelo ato [...] é um objeto social. Entendo por objeto social um objeto que responde a todas as partes do ato complexo, ainda que estas partes estejam na conduta de diferentes indivíduos. O objetivo do ato se encontra, pois, no processo vital do grupo e não só nos dos indivíduos separados.

11 Tradução nossa: "sú posicion, le concede la dignidade de ser un miembro de la comunidade, constituye la fuente de su reacción emocional a los valores que le pertenecen como miembro de la comunidade. Es la base de su incoporación a la experiencia de otros".
}

O Mim diz respeito, portanto, não só às exigências cognitivas do comportamento, mas também às expectativas morais estabelecidas na relação intersubjetiva.

Já o Eu só se manifesta nas relações práticas e representa as novas reações dos sujeitos frente às atitudes dos demais. É nesta dimensão que se torna possível a manifestação da liberdade diante das situações sociais formalizadas. Assim, o Eu é o receptáculo das reações impulsivas do self e apresenta-se como dimensão capaz de proporcionar mudanças na estrutura social, já que emerge através das manifestações espontâneas de novos conteúdos, os quais apresentam resistência às convenções normativas (Mead, 1973).

Se para Mead (1973) o Mim representa a imagem que o outro tem do indivíduo, (necessária para a apreensão da própria identidade) este último só se torna capaz de desenvolver o Eu a partir do julgamento sobre questões práticas, estabelecido na perspectiva do Mim. Isto significa que o Eu só existe a partir do Mim.

E se, como já dissemos, o Mim concretiza a presença do outro na consciência do indivíduo, este só será capaz de reagir em contraste às convenções normativas (manifestando a dimensão do $\mathrm{Eu}$ ) se a priori, estiver apto a compreender, a partir da perspectiva do outro, as regulamentações sociais, assumindo-as como referências e aplicando-as na relação prática consigo mesmo (Mattos, 2006). Assim, o indivíduo só toma consciência de si mesmo na condição de objeto e "na medida em que ele aprende a perceber sua própria ação da perspectiva, simbolicamente mediada, de uma segunda pessoa" (Mead apud Honneth, 2003, p. 31).

Voltando à ideia de incorporação de regras, podemos localizar o conceito de "outro generalizado". Tal acepção remete às elaborações de Mead (1991) sobre o processo de socialização, que ele ilustra a partir de duas atividades lúdicas infantis denominadas play e game.

Neste processo, o indivíduo torna-se capaz tanto de adquirir consciência de si a partir da relação com um outro (play), quanto de 
absorver as normas e valores socialmente válidos, o que garante a capacidade de interação, a partir da previsão de respostas ou padrões de comportamento esperados num ambiente com regras estabelecidas (game). E uma vez que este indivíduo seja capaz de incorporar tais regras, sua reiteração no contexto social torna-se desnecessária, de forma que as normas se estabelecem no processo de autoconsciência (Mead, 1973, 1991).

O outro generalizado pode ser representado por sujeitos, grupos ou imagens, objetos físicos associados às convenções sociais. É a forma concreta através da qual a sociedade opera sobre o indivíduo, constituindo um elemento de mediação entre este e a sociedade. Seu desenvolvimento constitui o resultado do processo de socialização e se caracteriza como a incorporação (absorção) e generalização das expectativas de comportamento da sociedade e/ou comunidade.

Tal processo irá possibilitar a internalização (apropriação crítica) do mundo exterior, e a partir dele abrem-se as possibilidades de compreensão dos direitos e deveres na relação com os outros, de forma que as pretensões de reconhecimento se estabelecem:

Se o sujeito, pelo fato de aprender a assumir as normas sociais de ação do "outro generalizado", deve alcançar a identidade de um membro socialmente aceito de sua coletividade, então tem todo o sentido empregar para essa relação intersubjetiva o conceito de "reconhecimento": na medida em que a criança em desenvolvimento reconhece seus parceiros de interação pela via da interiorização de suas atitudes normativas, ela própria pode saber-se reconhecida como um membro de seu contexto social de cooperação. A própria proposta de Mead é falar aqui de uma relação de reconhecimento mútuo (Honneth, 2003, p.136, grifos do autor).

Deste modo, a proposição meadiana de outro generalizado nos permite também a compreensão acerca do reconhecimento jurídico, pois, com base nas reações de reconhecimento de seus parceiros de interação, os indivíduos podem saber-se confirmados portadores de direitos comuns a uma coletividade. Além disto, através da apropriação crítica dos conteúdos normativos, são capazes de ampliar a extensão dos direitos garantidos, elevando o grau de autonomia pessoal (Honneth, 2003).

Ainda segundo Mead (1973), existe uma tensão permanente entre o Eu e o Mim, uma vez que o Eu representa a dimensão da reação prática espontânea e inovadora, que ocorre em contraponto ao conteúdo normativo incorporado pelo Mim:

Mas, se esse potencial de reação criativa do "Eu" é concebido como contraparte psíquica do "Me" [Mim], então, salta à vista rapidamente que a mera interiorização da perspectiva do "outro generalizado' não pode bastar na formação da identidade moral; pelo contrário, o sujeito sentirá em si, reiteradamente, o afluxo de exigências incompatíveis com as normas intersubjetivamente reconhecidas de seu meio social, de sorte que ele tem de pôr em dúvida seu próprio "Me" [Mim]. Esse atrito interno entre "Eu" e "Me" [Mim] representa para Mead as linhas gerais do conflito que deve explicar o desenvolvimento moral tanto dos indivíduos como das sociedades (Honneth, 2003, p.141, grifos do autor).

A ideia de uma tensão permanente entre autonomia (reação criativa do Eu) e heteronomia (conteúdo normativo incorporado pelo Mim) será utilizada por Honneth (2003) como fundamentação à sua tese de que o conflito é o principal motor do desenvolvimento moral das sociedades, além de corroborar a noção da produção de uma identidade social também essencialmente conflitiva, que ocorre em meio às pretensões da individuação e a regulamentação estabelecida pela vontade global internalizada.

Este material é utilizado por Honneth (2003) como complementação e aprofundamento teórico às ideias de Hegel, de forma que o autor compreende que o trabalho de Mead traz novos elementos a uma teoria do reconhecimento, na qual a intuição hegeliana original pôde ser reiterada e atualizada nos termos de uma teoria social empiricamente sustentada e de bases epistemológicas compatíveis com o pensamento contemporâneo. 


\section{Referências bibliográficas}

Farr, R. M. (2008). George Herbert Mead: filósofo e psicólogo social. In: As raízes da Psicologia Social Moderna (pp.79-112). Petrópolis: Vozes.

Habermas, J. (2002). Individuação através da socialização: sobre a teoria da subjetividade de George Hebert Mead. In: Pensamento pósmetafísico (pp.183-234). Rio de Janeiro: Tempo Brasileiro.

Honneth, A. (2003). Luta pelo reconhecimento: a gramática moral dos conflitos sociais. São Paulo: Editora 34.

Laclau, E. (1986). Os novos movimentos sociais e a pluralidade do social. Revista do CEDLA, Latin American Studies, 29. Traduzido do inglês pela Tradutec, São Paulo.

Mattos, P. (2006). A sociologia política do reconhecimento: as contribuições de Charles Taylor, Axel Honneth e Nancy Fraser. São Paulo: Annablume.

Mead, G. H. (1973). Espíritu, persona e sociedad. Barcelona: Paidós.

Mead, G. H. (1991). La génesis del self y el control social. Revista Española de Investigaciones Sociológicas. Madrid, 55, jul./set. [Original publicado em 1925, pelo International Journal of Ethics, (35), 251277]

Ramos, C. A. (2002). Hegel e o processo de autorreferencialidade da liberdade no direito natural moderno. Cad. Hist. Fil. Ciências, v. 12, n. 1-2, 105-128, jan/dez.

Souza, L. G. da C. (2009). Reconhecimento como Teoria Crítica? A Formulação de Axel Honneth. Dissertação de mestrado não publicada, Programa de Pós-graduação em Sociologia, UNICAMP. Campinas: São Paulo.

\section{A noção de pessoa e a persona corporativa}

Heli de Andrade

Omo objetivo desse texto, gostaria de analisar como a Psicologia Social poderia nos ajudar a entender melhor o processo de formação da pessoa dentro do mundo corporativo.

Antes de adentrar na noção de pessoa e na sua relação com a persona corporativa, é importante caracterizar o que vem a ser essa persona corporativa. Esse conceito é advindo da área de Administração e tem o propósito de abranger a pessoa e o papel/função que ela exerce dentro de uma determinada organização, que seria a corporação da qual essa pessoa faz parte como funcionário remunerado no exercício de sua atividade profissional.

Essa pessoa, desde o momento em que se aproxima de uma determinada organização, começa a ser submetida a uma gama particular de influências que caracterizam o que passaremos a chamar nesse texto de cultura organizacional.

Em um primeiro momento, essa influência se dá através de informações que essa pessoa colhe e recebe de fontes externas ou internas à organização. Com base nessas informações ela tem a oportunidade de contrastar os seus valores e princípios, ou seja, o que entende por ser o conjunto de seus atributos pessoais, com o que ouviu e aprendeu sobre aquela organização e tem a oportunidade de fazer uma avaliação prévia sobre como seria vivenciar a experiência de trabalhar naquela organização. Não há dúvidas de que nesse momento essa avaliação é um tanto superficial e outros fatores socioeconômicos podem ser muito mais relevantes na tomada de decisão de vir a trabalhar naquela organização. Uma vez dentro da organização, as influências passam a ser diretas e reais, e a pessoa começa rapidamente a identificar o que aquela cultura organizacional significa em termos de comportamentos e atitudes daqueles que nela vivem, 
e como essa cultura impacta o seu dia-a-dia dentro daquela organização. Entretanto, essa leitura daquele ambiente corporativo é ainda muito limitada pelo grau de exposição que a pessoa tem dentro da organização e pela dimensão relativa da atividade da sua unidade de trabalho dentro do contexto maior da organização. Assim, com o tempo esse processo de aculturamento se aprofunda e a pessoa vai se tornando mais um ativo representante daquela cultura.

No desenvolvimento da carreira corporativa, ao alçar postos de liderança- ou seja, comandar equipes de trabalho - a pessoa passa a ser responsabilizada diretamente ou indiretamente por representar, valorizar e repassar os valores daquela cultura organizacional aos seus comandados. Algumas organizações são explícitas nessa responsabilização e buscam ajudar os seus líderes nessa tarefa através de inúmeros cursos de formação de liderança. Outras organizações não oferecem tal apoio e não colocam essa responsabilização de forma clara aos seus líderes, mas cobram assim mesmo, pois entendem que se aquela pessoa pode assumir o papel de líder naquela organização é porque ela está imbuída dos valores da organização e, portanto, ela deveria ser um exemplo para sua respectiva equipe.

Assim como a sociedade evolui, essa cultura organizacional também vive o seu processo de evolução, mas em um ritmo mais acelerado, sejam por inovações administrativas que são impostas pelos controladores ou mesmo pelo mercado, ou por fatos do mundo corporativo como fusões, aquisições, entrada em novos mercados ou internacionalização.

Nesse processo evolutivo da organização espera-se que os bons líderes sejam capazes de, rapidamente, se adaptar aos novos tempos, de absorver e disseminar ativamente a nova cultura organizacional vigente, isto sem abrir mão de continuar a obter alto desempenho econômico. Como referência teórica que aborda essa questão da liderança e para entender como uma pessoa seria capaz de exercer esse papel e conviver com esses desafios de uma forma saudável, seguirei como base a teoria do desenvolvimento da "Inteligência Emocional", de Daniel Goleman, psicólogo americano, $\mathrm{PhD}$ pela Harvard University.

\section{A Pessoa corporativa e a Inteligência Emocional/Social}

Dentro deste contexto corporativo, um conceito muito utilizado na área de Administração com relação à caracterização dessa persona corporativa advém do trabalho de Daniel Goleman (1996) Inteligência Emocional.

Essa caracterização tem como princípio uma visão essencialista, pois considera que a pessoa é essencialmente boa e pura, mas que essa bondade e essa pureza vão se perdendo na medida em que essa pessoa vai sendo transformada ao longo da sua vida, dentro dos contextos dos quais participa, sendo o ambiente do trabalho um desses contextos, cuja importância pode variar de pessoa para pessoa, mas sem dúvida, trata-se de um dos contextos mais importantes da vida de uma pessoa nos tempos atuais.

Um dos maiores legados de Goleman para a Administração é o de mostrar caminhos e tecnologias para o desenvolvimento da "Inteligência Emocional". Esse desenvolvimento proporcionaria à pessoa o autoconhecimento necessário para que ele possa desenvolver uma transformação reversa no sentido de conhecer a sua essência. Ao desenvolver o seu autoconhecimento, a pessoa passaria a entender cada vez melhor não somente suas próprias emoções e sentimentos, mas as emoções e sentimentos daqueles que o cercam, tornando-se mais eficaz nas suas relações e, principalmente, na administração de conflitos característicos na vida corporativa.

Assim, esse conceito tem servido de base para muitos treinamentos corporativos que visam à formação de lideranças internas, possibilitando à pessoa que desenvolve sua "Inteligência Emocional" a capacidade de se adaptar e de lidar de maneira mais saudável com as demandas da vida do trabalho dentro de uma organização. Portanto, na sequência da linha de argumento, busquei organizar e mostrar algumas contribuições advindas da Psicologia Social que nos permitirão compreender e definir melhor essa pessoa corporativa. Nesse estudo, selecionei três autores que nos ajudarão nessa busca, a saber: George H. Mead, Michael Foucault e Nikolas Rose. 


\section{Psicologia Social e a construção da pessoa}

O primeiro autor que mencionarei é George Herbert Mead, filósofo americano da Escola de Chicago, cujo trabalho foi muito importante para a Psicologia Social. De Mead pode-se extrair várias contribuições no sentido de se caracterizar o processo de construção da nossa persona corporativa. $\mathrm{O}$ desenvolvimento do self, a caracterização do controle social, a importância da linguagem do grupo ao qual a pessoa pertence, o conceito do outro generalizado, a conceituação da distinção e da junção do " $P$ " e do "me"; todos esses conceitos são muito relevantes na compreensão que buscamos. Em um trecho do seu livro Mind, Self and Society (1992), na parte III, The Self, Mead afirma:

A autoconsciência do indivíduo humano, então, toma ou assume as atitudes sociais organizadas de um dado grupo social ou comunidade (ou de um subgrupo deste) ao qual ele pertence, na direção dos vários tipos de problemas sociais que aquele grupo ou comunidade enfrenta em um dado momento, e que aparecem em conexão com os correspondentes projetos sociais ou iniciativas cooperativas nas quais aquele grupo ou comunidade está engajado; e como um participante individual nestes projetos ou iniciativas cooperativas, ele então governa sua conduta (p.156). ${ }^{1}$

Nesse processo de emergência do self, ele vai assumindo formas distintas conforme mudam as condições do ambiente em que ele está inserido. Segundo Mead, o self emerge nesse contexto dinâmico, onde são desenvolvidas as habilidades para se comunicar e adotar atitudes condizentes com o grupo ao qual ele pertence. Pode-se dizer que esse contexto dinâmico, ao mesmo tempo em que propicia o desenvolvimento desse self, exerce um controle social, na medida em que estabelece limites para a comunicação e a participação naquele determinado grupo, por meio da linguagem própria daquele grupo, nas palavras ou nos gestos usados pelo grupo, e também nas atitudes, que embora não sejam previamente definidas ou ditadas, são atitudes "aceitas" pelo grupo. A esse grupo social ou

\footnotetext{
${ }^{1}$ Tradução do autor
}

comunidade organizada que propicia ao indivíduo a expressão do seu self Mead chama de o outro generalizado.

Essa experiência pode ser perfeitamente transposta ao ambiente corporativo, com a sua cultura organizacional própria, com a sua linguagem própria, com suas regras próprias. E o indivíduo que nela se situa aprende a se comunicar, a agir conforme as expectativas daquele contexto. $\mathrm{E}$ as mudanças culturais e organizacionais que vão ocorrendo ao longo do tempo trazem essa dinâmica que faz com que o self daquele indivíduo esteja em constante evolução. Mas, por outro lado, como são cada vez mais frequentes essas mudanças da cultura organizacional, a pessoa corporativa se vê imersa em um processo onde não estão claras as regras vigentes, onde o controle social é exercido de forma não homogênea por diferentes grupos dentro da corporação, tornando a experiência da vivência e da sobrevivência neste outro generalizado um grande desafio pessoal.

Devemos ter claro que estamos tratando de uma parte do self, de um self particular daquela pessoa, não do seu self completo. Esse self, portanto, não se caracteriza pela unidade, pois pode estar mudando no tempo e também no espaço de convivência da pessoa, com diferentes selves nas diferentes relações com diferentes pessoas ou grupos e em diferentes situações. O que viria a ser o self completo seria o reflexo da totalidade do processo social em que a pessoa está inserida.

Dando sequência na análise desse processo de formação da persona corporativa na visão da Psicologia Social, apresentarei a seguir algumas das contribuições do filósofo francês Michel Foucault, e para isso baseei-me no texto de Marcio Alves da Fonseca (2003), intitulado Michel Foucault e a constituição do sujeito, de onde pode se extrair conceitos importantes para o nosso estudo.

O autor retrata a concepção de Foucault sobre as formas de exercício do poder, mas precisamente discutindo a disciplina como estratégia política. Em um trecho do texto, dentro do capítulo "Vigilância e controle sobre o desenvolvimento", M. Fonseca nos trás um retrato do 
exercício do poder através da vigilância que se apresenta de forma leve e natural, permeando nossa vida em um modelo que se enquadra perfeitamente na vivência corporativa.

A vigilância como instrumento da disciplina é que permite a essa estratégia de poder não necessitar recorrer à força para se realizar. Ela transfere a necessidade de qualquer limitação sobre o vigiado para ele mesmo. [...] O indivíduo vigiado é que se transforma no princípio de sua própria sujeição. Assim, o louco se força à calma, o operário ao trabalho, o aluno à aplicação, o criminoso à retidão de comportamento (p.57).

Mais uma vez, fazendo um paralelo com o ambiente de uma corporação, é possível identificar claramente essa estratégia política em ação, com todas as diretrizes e orientações comunicadas, todo um aparato de vigilância, formais (inspetorias, auditorias) e informais (chefias, colegas, monitoramento de e-mails, de acesso à Internet etc.) e de punição, desde os casos detalhados nos, hoje comuns, manuais de ética corporativa até a perda simples e sem motivo maior do emprego. Outra ferramenta muito utilizada no contexto corporativo é o exame, conforme descrito abaixo:

[...] pelo exame, o indivíduo passa a ser uma peça de um dispositivo estratégico que permite uma série de utilizações. $\mathrm{O}$ indivíduo enquanto caso é, ao mesmo tempo, o indivíduo tal como pode ser descrito, mensurado, medido, comparado a outros e isso em sua própria individualidade; e é também o indivíduo que tem que ser treinado ou retreinado, tem de ser classificado, normalizado, excluído, etc. (Foucault, 1988, p.170).

Uma prática também comum na atividade corporativa, definida por Foucault como uma ferramenta de exercício do poder, é o "controle das atividades", cujo princípio básico é de que nas atividades investidas pelos indivíduos, não deveria haver lugar para gestos inúteis ou ociosos.

Complementando nosso estudo, passarei agora a avaliar o conceito de subjetivação trazido pelo sociólogo britânico Nikolas Rose (2001) em seu texto Inventando nossos eus. Esse conceito é revelador na forma como podemos entender outro lado pelo qual se dá o processo de construção da persona corporativa. Um bom exemplo desse conceito pode ser obtido na seguinte afirmação de Rose:

Uma vez tecnicizadas, maquinadas e localizadas em lugares e práticas, emerge uma imagem diferente do processo de "construção de pessoas". As pessoas funcionam, aqui, como uma forma inescapavelmente heterogênea, como arranjos cujas capacidades são fabricadas e transformadas por meio de conexões e ligações nas quais elas são apreendidas em locais e espaços particulares. Não se trata, portanto, de um eu que emerge por meio da narração de estórias, mas, antes, de examinar o agenciamento de sujeitos: de sujeitos combatentes em máquinas de guerra, de sujeitos laborais em máquinas de trabalho, de sujeitos desejantes em máquinas de paixão, de sujeitos responsáveis nas variadas máquinas da moralidade. Em cada caso, a subjetivação em questão não é produto nem da psique nem da linguagem, mas de um agenciamento heterogêneo de corpos, vocabulários, julgamentos, técnicas, inscrições, práticas (p.166).

No contexto da vida corporativa, não é difícil enxergar e identificar as tecnologias de subjetivação que um indivíduo passa a vivenciar desde a sua integração aos quadros daquela organização. E quanto mais integrado e sujeitado àquelas particulares tecnologias, mais sucesso terá em ser agente ativo da disponibilização, e da implantação e aplicação dessas tecnologias junto a outros membros da organização. E passa a atuar até mesmo no desenvolvimento de novas tecnologias. E muitos desses agentes passarão a ocupar os cargos de liderança da organização e serão vistos como exemplos a serem seguidos, a serem copiados. Nikolas Rose faz menção em seu texto a essa força que move o indivíduo a copiar modelos de sucesso e a não copiar modelos de fracasso.

Eis que nos deparamos então com uma das principais incongruências do mundo corporativo. Pois os líderes que são vistos e identificados como vencedores em suas respectivas carreiras corporativas são copiados pelos mais novos que aspiram ao mesmo sucesso. Entretanto, esses líderes foram reconhecidos e subiram na hierarquia corporativa principalmente pelos resultados que apresentaram em suas atividades e seus comportamentos e atitudes não necessariamente representam a cultura organizacional que a 
corporação está pregando naquele dado momento. Mas, dado o respaldo e o poder que têm na organização, não se sentem tão impelidos a readequarem seus comportamentos e atitudes às exigências da nova cultura. Nesse meio ficam os novos líderes ou aspirantes a líderes, sendo treinados e avaliados sob as diretrizes dessa nova cultura, e no dia-a-dia, não observam em seus respectivos chefes o exemplo esperado e, muitas vezes, encontram comportamentos e atitudes contraditórias e até mesmo opostos ao que é recomendado pelas atuais diretrizes corporativas.

Rose, ainda detalhando o processo de subjetivação, traz um texto de Foucault que mostra a disciplina como uma dessas máquinas/tecnologias de subjetivação, exercendo o seu poder de uma forma indireta e positiva:

[...] isso "diagrama" um ser que, do interior dos discursos que o rodeiam e das práticas pelas quais ele é agenciado/montado, é capacitado a saber, ou obrigado a saber, aquilo que está em sua positividade - um ser que pensa a si mesmo tanto como livre quanto como determinado pelas positividades essenciais a si mesmo, que delimita a possibilidade de suas práticas de liberdade no mesmo momento em que concede a essas positividades o status de verdade (Rose, 2001, p.197).

Em outra de suas obras, Governando a alma: a formação do eu privado. N. Rose (1998) nos traz mais detalhes sobre esse processo de subjetivação, que age sobre nossas personalidades, subjetividades e relacionamentos, em suma sobre o que consideramos como nossa vida privada e, ingenuamente, podemos vir a acreditar que nesses lugares encontraremos nossos verdadeiros eus.

Segundo N. Rose, a vida organizacional adquiriu um matiz psicológico, e essa forma de atuação ele denomina como típica da organização moderna. Essas organizações moldam o que ele define como o sujeito cidadão, que tem como positividade o fato de que o alinhamento de seus objetivos e ambições pessoais com os objetivos institucionais passa a ser muito valorizado. A esse conjunto de relações que governa as interações entre esse cidadão e essas instituições N. Rose dá o nome de "técnicas do eu".
[...] técnicas do eu: as formas pelas quais nós somos capacitados, através das linguagens, dos critérios e técnicas que nos são oferecidos, para agir sobre nossos corpos, almas, pensamentos e conduta a fim de obter felicidade, sabedoria, riqueza e realização. Através da autoinspeção, da autoproblematização, do automonitoramento e da confissão, avaliamos a nós mesmos de acordo com critérios que nos são fornecidos por outros (p.43).

Sem dúvida, no mundo corporativo somos guiados por essas técnicas, mas há toda uma construção de um contexto que procura nos fazer acreditar que estamos sendo os guias de nossas carreiras, fingem que valorizam nossa singularidade, nos fazem donos do processo de criação de novas técnicas de subjetivação e quando nos damos conta, se é que um dia nos damos conta, o que entendemos como nossas metas pessoais, nosso caminho para a felicidade, com certeza estará profundamente imbricado com objetivos institucionais.

\section{Considerações finais}

Podemos concluir, sem sombra de dúvidas, que os olhares da Psicologia Social, ao analisar o processo de constituição de uma pessoa, possibilitam uma compreensão mais profunda do mundo particular da constituição e da vivência da pessoa corporativa.

Nos três autores selecionados, Mead, Foucault e Rose, pode ser identificada uma estrutura central no processo de formação da pessoa, o qual se concretiza a partir das transformações pessoais resultantes da interação constante da pessoa com o meio social em que está inserido.

No nosso foco de interesse, podemos afirmar que o ambiente corporativo não é o único, mas é o principal meio social a impactar a formação dessa pessoa corporativa. Além da corporação, os demais ambientes sociais nos quais a pessoa está inserida também têm influência nesse processo, na medida em que neles se manifestam expressões da relação da pessoa com o trabalho, sem dúvida uma das principais relações da vida da pessoa. 
Mead traz uma visão desse processo de evolução na perspectiva da pessoa e da constituição do seu self, de como uma pessoa é impactada dentro de um determinado meio social, quais são as forças que a influenciam e como essa influência acontece. Além disso, um conceito muito importante que Mead nos traz é o da existência de diferentes selves particulares de uma mesma pessoa, resultantes dos diferentes contextos sociais em que a pessoa vive.

Já Foucault e Rose trazem uma visão que complementa muito bem esse entendimento do processo, pois esclarecem como a sociedade e suas organizações públicas ou privadas, seu aparelhamento institucional; como tudo isso é utilizado para desenvolver e programar ferramentas e tecnologias que venham a exercer a influência, a força de transformação a qual as pessoas de uma sociedade são subjetivadas. E como todo esse processo de subjetivação se estabelece nas sociedades modernas de uma forma positiva, sutil, aceita sem maiores resistências, como se tudo fosse um processo de evolução natural das sociedades.

Quando se restringe essa análise para o mundo corporativo, torna-se claro e evidente todo esse processo de subjetivação da pessoa corporativa. Trata-se de ambientes onde o controle social se faz mais presente, onde a relação de trabalho impõe maiores graus de obediência e de sujeição, onde a possibilidade e o medo de ser excluído do grupo são permanentes.

Por outro lado, como descrito por Rose (2001), as próprias aspirações e imagens de sucesso felicidade dessas pessoas passam a ser constituídas por caracterizações de sucessos advindos desse mundo corporativo onde ele está mergulhado e assim passam a dirigir suas atitudes e comportamentos na direção desejada pela corporação.

Em resumo, podemos concluir que a Psicologia Social tem muito a contribuir para que possamos melhor entender e ajudar essa pessoa corporativa. E isso é possível conhecendo a Cultura Organizacional de uma determinada corporação, mas com um olhar exploratório de seu contexto dinâmico (ferramentas, regras, linguagem, mecanismos de reconhecimento e promoção etc.), através do qual essa corporação busca influenciar as pessoas que nela vivem.

\section{Referências bibliográficas}

Goleman, D. (1996) Inteligência Emocional. Rio de Janeiro, Editora Campus.

Mead, G. H. (1992) Part III: The Self. Capítulos: 18, 19, 20, 21, 22, 25, 29. In: . Mind, Self, \& Society: from the standpoint of a social behaviorism. USA: The University of Chicago Press.

Fonseca, M. (2003) A disciplina como estratégia política. In: Michel Foucault e a constituição do sujeito (pp.39-71). São Paulo, EDUC.

Rose, N. (2001) Inventando nossos eus. In: Silva, T. T. D., (Org.). Nunca fomos humanos: nos rastros dos sujeitos (pp.137-204). Belo Horizonte: Autêntica.

Rose, N. (1998) Governando a alma: a formação do eu privado. In: Silva, T. T. D., (Org.). Liberdades reguladas (pp.30-45). Petrópolis: Vozes. 


\section{A transformação através do processo de Coaching}

\section{Fernando Fernandes Pimenta}

E só muitos anos depois viríamos a descobrir que, para os outros, não éramos precisamente isto que somos - mas aquilo que os outros veem...

Há casos em que alguns acabam adaptando-se a essas imagens enganosas, despersonalizando-se, para o resto da vida num segundo "eu". O eu dos outros...

Mário Quintana em Porta Giratória (2007, p.38).

A articulação teórica a ser feita no presente texto, terá como eixo norteador o relato de um processo de coaching ${ }^{1}$ de uma cliente, cujo fragmento de história de vida é relatado a seguir.

A cliente chama-se Cristina ${ }^{2}$, tem 42 anos de idade e ocupa há alguns anos a diretoria de uma grande multinacional na cidade de São Paulo. Recentemente procurou um coach a fim de obter ajuda através de um processo de coaching de vida. ${ }^{3} \mathrm{Na}$ sua primeira sessão com o coach, Cristina contou-lhe que nos últimos vinte anos têm se submetido a diversos processos psicoterápicos, de forma descontínua e com terapeutas de

\footnotetext{
${ }^{1} \mathrm{O}$ processo de coaching é uma forma de apoio ao cliente que visa ajudá-lo a melhorar sua vida pessoal ou profissional e alcançar seus objetivos. Seu método de aplicação utiliza recursos da Psicologia, Filosofia e Educação, para que, de uma maneira objetiva, possa propiciar um processo de autorreflexão. Limita-se a cerca de doze sessões entre o coachee (cliente) e o coach (profissional que conduz o processo).

${ }^{2}$ Nome fictício.

${ }^{3}$ Coaching de vida (life coaching) é uma das aplicações do processo de coaching, que visa ajudar o cliente a buscar uma solução para um problema de ordem geral (não profissional), que não está resolvido em sua vida.
}

diferentes abordagens. Avalia que a terapia lhe tem feito muito bem e que não consegue se imaginar sem este suporte.

Em seguida, contou de forma metafórica qual foi a questão que a levou a procurar o coaching. Considera que sua vida está como que presa em uma armadilha. Pensa que se pudesse, reescreveria seu roteiro de vida, desde há muito tempo atrás. Embora pretenda continuar fazendo terapia, acha que o processo de coaching lhe será mais efetivo nas mudanças que pretende que aconteçam em sua vida.

Seu relato é de que tem vivido a vida que foi definida por seus pais. Entre as várias histórias que contou, destacam-se as seguintes: cursou engenharia por escolha de seus pais, mas sua preferência seria por Psicologia. O seu primeiro emprego, onde se mantém até hoje, foi conseguido há dezesseis anos por solicitação de seu pai a um amigo que ali trabalhava. Há seis anos tornou-se diretora da empresa, que é muito conservadora e com uma cultura que não lhe agrada. Tem se saído muito bem na carreira profissional, em razão de sua dedicação e comprometimento. A promoção ao cargo de diretora foi um reconhecimento pelo seu desempenho. Entretanto, não fosse pelo receio de causar um desgosto ao pai, já teria, desde longa data, procurado outra empresa, aonde pudesse ter mais liberdade e ser mais criativa e feliz.

Mora sozinha em local próximo para ficar mais tempo no trabalho. Tem poucos amigos, pois é difícil mantê-los devido a sua intensa agenda de compromissos. Seus relacionamentos sentimentais foram raros. Há oito anos conheceu um rapaz e apaixonou-se pela primeira vez. Sobre este acontecimento Cristina fez o seguinte relato:

Não me lembro de nenhum outro momento em minha vida que tenha sido mais feliz. Infelizmente o rapaz não pertencia a minha classe social, não tinha curso universitário e trabalhava como balconista em um pequeno comércio. Ao imaginar que meus pais poderiam não aprovar o relacionamento, senti-me obrigada a me afastar dele, antes mesmo de apresentá-lo a eles. Depois disso como não apareceu nenhum rapaz com um perfil aceitável, eu continuo sozinha. 
Poderíamos prosseguir com os fragmentos de sua história de vida, mas já temos elementos para poder iniciar nossas reflexões.

Desde a sua primeira sessão com o coach, Cristina compreendeu que tem muito pouco ou quase nenhum controle sobre sua própria vida. Tem aceitado viver o que seus pais decidem ou como imagina que eles iriam decidir. Este comportamento faz com que seus pais a vejam como a filha ideal. Eles têm lhe elogiado muito ao longo dos anos.

Embora Cristina tenha abordado muitas vezes esse tema em sua terapia, não conseguiu alterar essa situação. Como esta condição lhe traz muito sofrimento, para conseguir algum alívio, justifica que as escolhas na sua vida não foram suas, isentando-se totalmente da responsabilidade pelo que passa atualmente.

Nos últimos anos ela tem percebido que tudo se transforma à sua volta, que a vida está em transformação. Lamenta que somente sua vida esteja estagnada e sem qualquer alteração. Imagina estar vivendo mais do mesmo e sente que continua sendo a mesma de sempre. Esta percepção agora a incomoda de tal forma, que pretende buscar a transformação e mudar sua vida. Ainda não sabe exatamente o que quer, ou aonde quer chegar, mas pelo que já ouviu falar, participar de um processo de coaching pode ajudá-la a definir e realizar seus objetivos.

Para buscar analisar este relato de Cristina vamos recorrer aos recursos da Psicologia Social, recorrendo a dois de seus importantes pensadores: Antônio da Costa Ciampa com sua teoria de identidademetamorfose e a George Mead com seu conceito de self. Acreditamos que se articularmos estas teorias, será possível compreender o relato de Cristina e o desafio que ela terá pela frente para realizar a transformação pretendida. Após explorar esta questão buscaremos compreender como o coaching poderá ajudar Cristina em sua jornada.

A teoria de identidade de Ciampa (1993) considera que a identidade é metamorfose humana, que se define pela "construção, reconstrução e desconstrução constantes, no dia-a-dia das experiências vividas" (Kolyniak
\& Ciampa, 1994, p.9). Entende que o processo de metamorfose se inicia no nascimento e continua até além de sua morte, pois os personagens podem servir de referência para a constituição da identidade de outros personagens.

Outra perspectiva nos traz Outeiral (2002) que vê a identidade como uma "colcha de retalhos" (p. 59), que é composta desde criança por retalhos de identificações, que ocorrem com os pais, outros parentes, amigos, vizinhos, artistas, esportistas, ídolos, professores, colegas, chefes, subordinados e outros membros da sociedade. Estas identificações se misturam e se fundem continuamente, constituindo "uma identidade, um indivíduo, alguém único no mundo, sem igual" (ibid., p.59). Essa identidade vai se transformando (metamorfoseando) ao longo da vida, expressando-se "na capacidade de construir novas identidades, integrando nelas as identidades superadas e organizando a si mesmo e as próprias interações numa biografia inconfundível" (Habermas, 1983, p.80).

Cristina se expressa através de diferentes papéis: filha, diretora da empresa etc. Mas ela "nunca comparece frente aos outros apenas como portadora de único papel, mas como uma personagem, como uma totalidade [...] parcial" (Ciampa, 1993, p.170). Para o autor não é possível viver sem personagens, "ao comparecer frente a alguém, eu me represento. Apresentome como representante de mim mesmo". Ainda assim, nunca expresso minha totalidade, "posso falar de mim, agir por mim, mas sempre estou sendo o representante de mim mesmo. $\mathrm{O}$ mesmo pode ser dito do outro frente ao qual compareço e que comparece frente a mim" (Ciampa, 1993, p.171).

Ciampa (1993) acrescenta que é a articulação dos diferentes personagens vividos no dia a dia pelo indivíduo que melhor representa a constituição da identidade e pondera, que "podemos dizer que as personagens são momentos da identidade, degraus que se sucedem círculos que se voltam sobre si em um movimento, ao mesmo tempo, de progressão e de regressão" (1993, p.198).

As relações sociais constituem-se desta múltipla rede de representações, que ao mesmo tempo conserva-se e transforma-se. Portanto 
"a identidade que se constitui no produto de um permanente processo de identificação aparece como um dado, e não como um dar-se constante, que expressa o movimento social" (Ciampa, 1993, p.171).

Mas se identidade é metamorfose, o que tem ocorrido com Cristina que se vê sendo sempre a mesma, enquanto tudo a sua volta se transforma? Estaria Cristina de alguma forma impedindo a metamorfose ou estaria ela criando apenas uma aparência de não metamorfose?

Se nos apoiarmos na teoria de Ciampa (1993) para analisarmos o relato de Cristina, podemos supor que ela está enredada pela mesmice, que se define por uma situação em que um indivíduo tem sua identidade sendo re-posta continuamente.

Analisando o relato de Cristina, ela está "interiorizando a personagem que lhe está sendo atribuída e identificando-se com ela" (p.163). Além disso, vemos que Cristina mantém uma "identidade pressuposta que é re-posta a cada momento" (p.163), portanto sua identidade "é vista como dada e não se dando, num contínuo processo de identificação" (p. 163). Para manter sua rede de relacionamentos, as ações e comportamentos de Cristina seguem se repetindo como em um ritual social que foi estabelecido nesta relação indivíduo/meio social. Por conta disso pode-se esperar, seja por parte dela ou de seu meio social, que seu comportamento tenha alto grau de previsibilidade, quanto a como ela age no presente ou agirá no futuro. $\mathrm{O}$ autor considera que "a identidade de um indivíduo é um processo que se constitui de sua temporalidade: passado, presente e futuro" (p. 198). Nas suas palavras "a expectativa generalizada de que alguém deve agir de acordo com suas predicações e, consequentemente, ser tratado como tal [...] re-atualiza uma identidade pressuposta, que assim é vista como algo dado" (p.163).

Cristina tem vivido uma identidade pressuposta. Segundo Ciampa (1993) "ela tem interiorizado e tornado seu aquilo que os outros lhe atribuem, predicando-se com isto" (p.131). Quando ainda no início, esta predicação é transparente, depois menos direta e visível e então velada e complicada. Abaixo, vamos ver como o autor explica o funcionamento do mecanismo que mantém a mesmice. Esta compreensão nos ajudará a entender o que se passa com Cristina:

Como ser social, sou um ser-posto. [...] A reposição da identidade deixa de ser vista como uma sucessão temporal, passando a ser vista como simples manifestação de um ser sempre idêntico a si mesmo na sua permanência e estabilidade. A mesmice de mim é pressuposta como dada permanentemente e não como re-posição de uma identidade que uma vez foi posta. Algumas personagens que compõem nossa identidade sobrevivem, às vezes, mesmo quando nossa situação objetiva mudou radicalmente. [...] $\mathrm{Na}$ verdade, evitar a transformação - manter-se inalterado - é impossível; o possível, e que requer muito trabalho, é manter alguma aparência de inalterabilidade, por algum tempo, como resultado de muito esforço para conservar uma condição prévia, para manter a mesmice. O ser humano também se transforma, inevitavelmente. Alguns, à custa de muito trabalho, de muito labor, protelam certas transformações, evitam a evidência de determinadas mudanças, tentam de alguma forma continuar sendo o que chegaram a ser num momento de sua vida, sem perceber, talvez, que estão se transformando numa cópia daquilo que já não estão sendo, do que foram. De qualquer forma, é o trabalho de reposição que sustenta a mesmice (Ciampa, 1993, p.164-165).

De alguma maneira a mesmice parece ter sido conveniente à Cristina, pois pouco ou nada fez para atingir a condição de ser-para-si, ${ }^{4}$ de buscar a emancipação e conseguir libertar-se de sua identidade-mito, aquela que oculta a metamorfose.

Para ampliar o nosso entendimento sobre a cliente Cristina, recorremos à teoria de George Mead (1967), ${ }^{5}$ onde destacamos sua noção de

\footnotetext{
${ }^{4}$ Ciampa (1993) considera ser-para-si como "buscar a autodeterminação (que não é ilusão de ausência de determinações exteriores): tornar-se escrava de si própria' (que de alguma forma é tentar tornar-se sujeito); procurar a unidade da subjetividade e da objetividade, que faz agir uma atividade finalizada, relacionando desejo e finalidade, pela prática transformadora de si e do mundo" (p.146)

${ }^{5}$ George Herbert Mead que viveu de 1863 a 1931, trouxe novas ideias, teorias e valiosas contribuições para a Psicologia e Sociologia. Embora atualmente seja reconhecido como um
} 
self. ${ }^{6}$ Ciampa e Mead comungam do entendimento de que o processo identitário se estrutura nas relações sociais. Segundo Mead o self se desenvolve no relacionamento social (atividades e experiências), "através da interação com o processo em si e com os outros indivíduos" (p.135), portanto não nasce com o indivíduo. Ciampa acrescentaria que "quando o indivíduo encarna suas relações sociais, configura sua identidade pessoal" (1993, p.127). Retornando a Mead (1967), o self é consciência de si ou consciência autorreflexiva, aquela decorrente das experiências com o mundo exterior e consigo mesmo.

Não sofre qualquer desenvolvimento quando ações e experiências, mesmo que envolvam os afetos, ocorrem por puro hábito, sem a participação do pensamento. Também as recordações que não estão relacionadas a datas específicas, pertencem às reações do hábito, portanto ocorrem sem o envolvimento do self.

Mead (1967) considera que "o self é um objeto para si mesmo" (p.136), que pode ser ao mesmo tempo sujeito e objeto, diferenciando-se de outros objetos ou do próprio corpo como organismo fisiológico. Por isso é representado por uma palavra reflexiva. Ele considera como autoconsciência o fato do indivíduo ser capaz de sair de si mesmo, "de maneira empírica" (p.138), de forma a tornar-se objeto para si mesmo. Assim ele "pode experenciar-se a si mesmo, indiretamente, a partir do ponto de vista de outros indivíduos, membros do mesmo grupo social ou do ponto de vista generalizado do grupo social a que ele pertence" (p.171). Ele participa com sua própria experiência como self ou indivíduo, "tornando-se um objeto para si mesmo, assim como os outros indivíduos são objetos para ele" (p.136). Acrescenta que o indivíduo torna-se "objeto para si mesmo

dos mais importantes autores da Psicologia Social Crítica, ele não foi considerado como figura central na história ou nos manuais de Psicologia Social.

${ }^{6}$ O Self, segundo Mead "surge e se desenvolve no processo da experiência dos indivíduos e suas ações no espaço de interações sociais. [...] e não poderia ser simplesmente empregado como sinônimo ou equivalente de "eu", personalidade, ego, ou ainda como prefixo "auto", representando a própria pessoa, de acordo com o que se registra nos dicionários" (Bazilli, 1998, p.59). somente se assumir as atitudes dos outros indivíduos em relação a si, no ambiente social em que ambos estejam envolvidos" (p.193).

Comportar-se como objeto para si mesmo, onde se identifica o self, ocorre quando o indivíduo responde a si mesmo ao questionar a outro indivíduo e a própria resposta torna-se parte de sua atuação, falando e respondendo a si-mesmo. Ou seja, estamos falando de um diálogo interno consigo mesmo, como se fosse uma conversação com outro indivíduo.

Este diálogo interno com si mesmo ocorre a partir do ponto de vista do outro generalizado e permite restabelecer a totalidade dos nossos pensamentos e sentimentos. Esses são representados apenas parcialmente (expressão de partes do self) quando comunicados pelo indivíduo durante sua interação social. No entender de McGraw (2001) é neste diálogo interno, que ocorre de maneira incessante, que nos percebemos no mundo e que afetará nosso autoconceito e nossa vida. A internalização de informações consistentemente positivas ou negativas durante o desenvolvimento do self poderá criar uma visão distorcida de si-próprio e do mundo, trazendo consequências à Fisiologia, à saúde, às emoções e à própria vida em geral. Ele acredita que é possível interferir diretamente neste diálogo interno, evitando assim, que traga consequências negativas ao indivíduo. Para tanto, sugere que estejamos atentos à "conversa" desenvolvida durante o diálogo interno.

Para Mead (1967, p.140) o "self é essencialmente uma estrutura social, e se desenvolve na experiência social. É impossível imaginar o self desenvolvendo-se fora da experiência social". Para tanto, o self utiliza-se da linguagem (palavras, gestos e expressão corporal) para o seu desenvolvimento. Ele considera que para manter a unidade do self no indivíduo é necessária a existência do "outro generalizado" (p. 154), que pode ser a comunidade organizada ou o grupo social. Sendo que a atitude do outro generalizado representa a atitude da comunidade por inteiro. Este outro generalizado pode ser um objeto ou conjunto de objetos, um ser animado ou inanimado. Considera que é através da atitude reflexiva (autoconsciência) em relação a este outro generalizado, que desencadeará o 
desenvolvimento do self. O outro generalizado assume tal importância que "pode desencorajar ou impedir o desenvolvimento positivo do self" (p.262).

A comunidade ou grupo social organizados que proporcionam ao indivíduo sua unidade de self podem ser chamados o outro generalizado. A atitude do outro generalizado é a atitude de toda a comunidade. (...) E na forma do outro generalizado que os processos sociais influem na conduta dos indivíduos neles envolvidos e que os completam; quer dizer, que é nessa forma que a comunidade exerce seu controle sobre o comportamento de seus membros individuais; porque, dessa maneira, o processo ou comunidade social entra como fator determinante, no pensamento do indivíduo. No pensamento abstrato, o indivíduo adota a atitude do outro generalizado para si mesmo, sem referencia a expressão que este outro generalizado possa assumir algum indivíduo determinado; e no pensamento concreto adota essa atitude na medida em que é expressa nas atitudes para a conduta por parte daqueles outros indivíduos junto com os quais estão envolvidos na situação ou ato social dados (Mead, 1967, pp.154-156).

Mead (1967) vai separar os participantes deste diálogo interno em duas entidades, o "eu" $(I)$ e o "mim" $(M e)$ sendo que "a consciência de si mesmo, atualmente operante no relacionamento social é um 'mim' objetivo, ou vários 'mim'(s) num processo contínuo e que implica em um 'eu' fictício sempre fora do seu campo de visão". O "eu" que no momento presente é memória e experiência, no momento futuro será "mim", porque eu serei "mim" ao relembrar o que "eu" disse.

O $e u$ é a ação do indivíduo frente à situação social que existe em sua própria conduta e se incorpora à sua experiência só depois que tenha levado a cabo o ato. Então tem consciência deste. Teve que fazer tal e qual coisa, e a fez. Cumpre seu dever e pode contemplar com orgulho o que foi feito. $\mathrm{O}$ mim surge para cumprir tal dever: tal é a forma em que nasce em sua experiência. Teria em si todas as atitudes dos outros, provocando certas reações; esse era o mim da situação, e sua reação é o $e u$ (Mead, 1967, p.175).

As teorias destacadas acima permitem uma base de entendimento do processo identitário de Cristina e de alguns dos componentes de sua estrutura psíquica, de acordo com os autores abordados.
Proponho voltarmos ao caso em análise e discutirmos a abordagem do processo de coaching em busca de solução às questões trazidas por Cristina.

Vamos definir melhor como se desenvolve o processo de coaching. A função do coach no processo de coaching é a de facilitar à autoconsciência, a identificação do potencial de realização, o reforço da autoestima, a definição dos objetivos, a elaboração e acompanhamento da realização do plano de ação e o reconhecimento das conquistas.

O processo de coaching através da autorreflexão, definição de metas, ações e comportamentos, facilita a eliminação das barreiras e obstáculos que impedem a plena metamorfose da cliente.

A participação do coach é a de facilitar o desenvolvimento, ou melhor, a transformação do cliente, ajudando-o na realização de seus desejos e objetivos, facilitando para que ele possa atingir sua autonomia, emancipação, autorrealização e êxito, através da concretização de seus desejos.

O coach não dá treinamento, não ensina, não define padrões, não avalia o desempenho. Além disso, não dá conselhos, dele não se exige senioridade, e não necessita ser especialista em qualquer atividade da vida do cliente. No coaching não é o coach e sim o cliente quem identifica e estabelece os objetivos que ele mesmo pretende atingir.

O coaching não se confunde com terapia, embora exista alguma sobreposição entre as duas abordagens, como construções teóricas similares, confidencialidade, relacionamento praticante-cliente etc. Enquanto na terapia o foco é tipicamente retrospectivo, relacionamentos anteriores, problemas e padrões de comportamento, no coaching as recordações não compõem o seu principal eixo, pois o processo se dá com foco no presente e no futuro, buscando a desvelar as possibilidades presentes e tendo em vista despertar a consciência para a ação. Durante as sessões de coaching, embora os afetos atravessem a linguagem do cliente, as dificuldades de ordem emocional, traumas, angústias e sofrimentos não são abordados, mas recomendados para um processo terapêutico com outro profissional. 
O coaching de Cristina foi favorecido pela sua intensa vontade de transformar-se, fator essencial para o sucesso do processo. O coaching desenvolveu-se da seguinte maneira: depois de contatar e entrevistar o coach que foi indicado por sua terapeuta, Cristina teve a primeira das doze sessões semanais contratadas. Para manter a necessária discrição, as sessões foram realizadas no consultório do coach.

A preocupação do coach desde a primeira sessão foi a de criar um autêntico vínculo de confiança com a cliente. Também dedicou-se a rapidamente buscar empatia e rapport $^{7}$ com Cristina. Preocupou-se em manter sua escuta ativa, concentrando-se totalmente na cliente e dispondo-se a sua plena aceitação. Empreendeu também a escuta estruturada, encorajando-a, apoiando-a nos esclarecimentos, sintetizando aquilo que foi se desvelando durante as sessões e estimulando-a a refletir sobre os assuntos.

Os anos de terapia têm ajudado Cristina a lidar com as questões emocionais de sua vida, mas faltava-lhe encontrar uma forma de fazer a transformação desejada acontecer. O interesse pelo coaching visou torná-la capaz de realmente transformar sua vida.

Ao longo das sessões, o coach adotou a abordagem G.R.O.W. ${ }^{8}$ de coaching, que considerou a mais adequada para as necessidades de Cristina. $\mathrm{Na}$ aplicação das quatro etapas do método, a cliente decidiu os objetivos que pretendia atingir e os indicadores para a verificação que o teria atingido, compreendeu plenamente a situação vivida atualmente, realizou o levantamento de todos os dados relevantes para a ação, definiu o plano de ação para realizar os objetivos definidos, determinou as datas para a realização de cada etapa e estabeleceu as principais dificuldades e

\footnotetext{
${ }^{7} \mathrm{O}$ rapport diz respeito à capacidade do coach de se sincronizar com a cliente, em um ambiente de abertura, confiança e confidencialidade favoráveis ao desenvolvimento do processo de coaching.

${ }^{8}$ G.R.O.W. é o acrônimo para Goal, Reality, Options, What/Wrap Up. Esta abordagem de coaching foi desenvolvida por John Whitmore em Coaching for Performance, 1996.
}

obstáculos que poderiam ocorrer na execução do plano, e quais as alternativas e recursos necessários para superá-los.

O coaching de Cristina só será considerado efetivo, se de alguma maneira, alcançar o esperado. E terá fracassado, se as pessoas relacionadas à cliente não perceberem a transformação pretendida em sua identidade, aquela que é percebida pelo outro.

A partir de então, a identidade de Cristina, concretizando-se (como metamorfose), deverá continuar a lançar-se ao futuro através de novos projetos de vida, que impliquem em transformação. E esses projetos deverão seguir seus desejos e efetivar-se em atividade, em ação.

\section{Referências bibliográficas}

Bazilli, C. et al. (1998). Interacioniosmo simbólico e teoria dos papéis: uma aproximação para a psicologia social. São Paulo. EDUC.

Ciampa, A. da C. (1977). Identidade social e suas relações com a ideologia. Dissertação de Mestrado. São Paulo. PUC.

. (1993). A Estória de Severino e a História de Severina. São Paulo. Brasiliense.

Habermas, J. (1983) Para a reconstrução do materialismo histórico. São Paulo. Brasiliense.

Hargrove, R. A. (2008). Masterful Coaching. San Francisco. Jossey-Bass.

McGraw, P. C. (2001). Self Matters. New York: Simon \& Schuster Source.

Mead, G. H. (1967). Mind, Self \& Society. Chicago. The University of Chicago Press. [publicado originalmente em 1934].

Outeiral, J. (2002) Conhece-te a ti mesmo. São Leopoldo. Unisinos.

Quintana, M. (2007) Porta Giratória. São Paulo. Globo. 


\section{A constituição do $e u$ trabalhador}

Antônio Fernando Gomes Alves ${ }^{1}$

"Toda verdade é simples - Não será essa uma mentira composta?" Nietzsche (1888)

$\mathrm{C}$ oncentra-se este ensaio em examinar as relações de trabalho no capitalismo diante dos ininterruptos avanços da tecnologia e os efeitos daí advindos sobre a constituição do trabalhador e - por consequência sobre o seu eu, parte indivisível do ser. Para Leontiev (apud Bezerra, 2004, p.1) “(...) concebemos a atividade vital do homem, diferenciada da atividade dos animais por ser mediada pela reflexão consciente, livre e por produzir incessantemente o novo (...)".

O fio condutor deste ensaio é a relação entre o trabalhador (homo faber) e o sentido de trabalho que sobre ele opera, o qual se denominou $\mathrm{eu}$ trabalhador.

Por trabalho entenda-se a concepção marxista no contexto do capitalismo, a atividade responsável diferenciadora entre homens e animais. É a transformação proporcionada pelo esforço humano que agrega valor à mercadoria, valor que, transformado em lucro, acumula-se nas mãos capitalistas. Quanto ao sentido de trabalhador, adotou-se o critério de trabalhador produtivo de Braverman (1987, p.353), aquele que "representa as relações sociais entre o capital e o trabalho, visto que [correspondia ao] meio direto de criar mais-valia". Essa mesma relação capital e trabalho estabelece a divisão das atividades produtivas em que os trabalhadores são agrupados, fortalecendo a individualidade como imperativo na produção. Essas atividades produtivas coordenam o indivíduo para um trabalho qualificado, e em casos extremos, provocam alterações psicossociais,

\footnotetext{
${ }^{1}$ Bolsista pela Coordenação de Aperfeiçoamento de Pessoal de Nível Superior (CAPES).
}

como esforço repetitivo, irritabilidade social, conflitos na relação interpessoal, entre outros, frutos da desarticulação das capacidades físicas e mentais que o capital comanda.

Ainda como resultado desse processo psicossocialmente desestruturante, termina por desestimular o indivíduo de tomar parte no desenvolvimento da coletividade em que está inserido, com suas capacidades humanas em equilíbrio, ou seja, suas funções físicas e psíquicas normais, sem nenhum distúrbio físico ou mental. A indústria transforma o trabalhador num indivíduo incapaz de controlar suas ações na sociedade, levando-o a praticar ações que comprometem a ordem social. A poluição sonora, pressão e exaustão da capacidade física e mental invariavelmente levam o trabalhador a algum desequilíbrio psíquico.

A especialização que a divisão do trabalho acarreta faz do capitalismo o sistema de maior expansão como ordem econômica para todos os países, gerando excedente de capital promovido pelas forças produtivas. Esse excedente decorre da utilização eficiente das forças produtivas (capital e trabalho). A força produtiva (trabalho) tem capacidade de gerar um excedente que valoriza a grandeza do capital total: a mais-valia (absoluta e relativa).

A mais-valia, abstraída do trabalhador mediante os meios de produção, potencializa-se com a aplicação da tecnologia incorporada às práticas desses trabalhadores pelas inovações produtivas.

Ainda que mais de um século já tenha decorrido da definição précapitalista de Marx, persistem os problemas por ele apontados e as relações sociais verificam-se em condições de exploração no avanço do capitalismo. Num mundo de relações trabalhistas complexas e globalizadas devido às novas tecnologias, não seria de se esperar que o trabalhador resistisse incólume ou que a definição de seu "eu" não sofresse variação.

Nessa exigência de modificação, o binômio pessoa-trabalho altera endógena e exogenamente as relações sociais produtivas. Endogenamente em relação às mudanças provocadas nas organizações e, consequentemente, no 
ambiente corporativo, demandando desse trabalhador novos comportamentos e novas atitudes, elevados grau de competitividade perante os demais, atitudes individuais de sobrevivência, entre outras. Será o "eu" trabalhador a síntese desse binômio, alterando dialeticamente a pessoa e a atividade do trabalho perante os valores construídos em equipe - tolerância, respeito e partilha, constituintes de uma identidade social em construção em face das forças de mercado? Segundo Foucault (Fonseca, 2003), a meta dessa economia disciplinar é fabricar homens dóceis e submissos, do que resultou a pessoa moderna. Sob essa perspectiva, a preocupação de Foucault concentra-se na constituição do indivíduo e muito menos numa abordagem essencialista na qual a disciplina que o modela está presente nas materialidades e sociabilidades postas nas relações do campo social.

Posicionar-se e pensar em face dessas mudanças e desafios ora postos exogenamente nas relações sociais que se estabelecem fora ou dentro da organização, no ambiente familiar, cotidiano ou mesmo no campo social, requer compreender a possibilidade de modelagem de outro trabalhador, o surgimento deste "eu" trabalhador. A construção dessa subjetividade é moldada numa trama social em que se busca constantemente entender, decifrar a relação singular/universal e as relações que dela se originam e transformam a sociedade. Numa "relação que se estabelece e se transforma continuamente entre ambos de forma dialética, indivíduo e mundo social não são estruturas separadas, mas sim polos extremos de um mesmo elo de continuidade" (Ribeiro, 2004, p.98), razão por que, reafirma Furtado (2002), a realidade "será sempre subjetiva".

Essa mesma realidade aponta como componentes de tais transformações as inovações e mudanças no contexto das relações econômicas e sociais, ganhando espaço na medida em que considera a convivência humana o ingrediente inerente da evolução social.

Tornou-se importante considerar que os novos conhecimentos não se reduzem a máquinas, equipamentos e processos, mas incorporam de forma essencial aqueles que as operam e diferenciam a sociedade atual: os sujeitos. Reconstruindo a visão existencialista, o sujeito é sempre um vir-a- ser em permanente superação, realçada por seus valores, como uma "bússola" para retomar o caminho. Esses sujeitos dotados de subjetividades completam o todo a partir das suas singularidades e particularidades, ainda que característica da vida cotidiana seja em geral o "manuseio grosseiro do singular", destaca Heller (2000), de um mundo histórico e dado. Agnes Heller procura capturar o cotidiano na sua forma mais precisa singularidade - cotidiano - particularidade -, cotidiano em que o sujeito, na sua historicidade, reflete a universalidade, consequências dessa singularidade, ainda que as particularidades possam ser desconhecidas, remetendo-nos a outros significados. Juntam-se aos outros para compor o todo, mas sem perder a consciência de si mesmas.

A construção desse conceito do "eu" assemelha-se a um mosaico pela multiplicidade que há em ambos de peças e encaixes. O mosaico é plural, mas existe tão somente porque se constrói a partir do singular, do encaixe multifacetado, sem que suas peças percam por isso forma ou contorno para compor a representação coletiva desse grupo ou mesmo desse trabalhador. Cada "eu" é continuamente tocado por outro, de onde se estabelecem as relações, os encontros e a reciprocidade no campo social. Resgata-se a noção de Moscovici (2010, p.153), pela qual "a ciência do conflito entre o indivíduo e a sociedade" acabou definindo parte dos estudos na Psicologia Social. Esclarecendo sua afirmação, o autor acrescenta que o social do qual o indivíduo faz parte "é estudado em termos da presença de outros indivíduos ou de 'numerosidade' não são realmente as características fundamentais do sistema que estão sendo exploradas, mas sim um de seus subsistemas - o subsistema das relações interindividuais". Interessa-nos em especial nesse contexto reafirmar como Moscovici permitiu um deslocamento conceitual ao valorar o seu pensamento ao destaque do papel da ontologia social expressa por Durkheim, vinculando sua aplicação nas relações interpessoais entre o social e o psicológico. Moscovici valorizou o seu campo de investigação ao atribuir à ação no cotidiano o destaque relevante para as construções das representações coletivas, ressaltando que essa representação é fruto da interação social e da socialização entre os 
indivíduos (Xavier, 2002). Assim como ele, cumpre resgatar mais uma vez que o social é algo intimamente ligado à condição humana e necessita ser tomado como "sinônimo de sociabilidade", como dirá Silva (2004), ao discutir uma genealogia da Psicologia Social.

Outro aspecto deste ensaio é o modelo de consciência política proposto por Salvador Sandoval, para quem a consciência política é composta por aspectos identitários, pela cultura socialmente construída e expressa na sociedade, por meio de um conjunto de valores e crenças internalizadas pelo trabalhador e pela perspectiva politizada do contexto social em que se localiza o sujeito. Uma vez que a construção da consciência política é um processo dinâmico e evolutivo, importa categorizar o "eu" trabalhador no aspecto dinâmico da estrutura das relações sociais, indissociável do movimento societal. Essas dimensões, segundo o modelo proposto por Sandoval, informam a consciência política de sujeitos individuais e coletivos. Mediante essa estrutura esquemática, oferece-nos o autor um modelo conceitual de consciência política entendida como um "[...] processo contínuo de elaboração de visões de mundo em seus sentidos normativos, pragmáticosituacionais e cognitivo-informativos" (Sandoval, 1989, p.70).

Tais exigências modificam a aplicação e formação das práticas na relação social, alteram prioridades e comprimem espaços de convivência, modificando significativamente a gênese do conceito desse trabalhador necessário à sociedade. Característica dos tempos modernos, a individualização impede a capacidade de construir o bem comum, o espaço comum de convivência, tendendo invariavelmente ao singular: o particularismo das necessidades construídas em que os fins justificam os meios. Eis o cenário em construção de uma nova realidade social, formatada na evolução de uma nova economia - ambiente propício ao surgimento de outro "eu" trabalhador?

\section{A relação produtiva na nova economia: Que trabalhador é esse?}

Em primeiro lugar, importa contextualizar a nova economia considerando a transição do capitalismo de base industrial para outra forma de expansão do capitalismo, classificada como "imaterial", em que a força produtora de maior relevo passa a ser o conhecimento. Os produtos da atividade do trabalho passam a ter como medida a quantidade de conhecimento utilizada no trabalho. É o conhecimento, o trabalho abstrato, que se cristaliza no produto e é ele que determina o valor a ser dado a esse produto.

Essa nova versão do capitalismo desloca a predominância da produção industrial para um processo chamado setor de serviços, acompanhado pelas relações humanas inerentes às práticas do trabalho. A produção capitalista permanece, mas o trabalho característico desse setor evidencia muito mais um esforço intelectual-cognitivo do que propriamente físico. É por esses dois pressupostos que a nova economia vem moldando o trabalhador e assegurando a transferência e ampliação da riqueza mundial pelos capitalistas, vetores da sociedade de consumo.

Em tempos de fortes mudanças tecnológicas, o debate sobre o trabalho e as relações que dele se originam ganha novo fôlego. Uma das questões debatidas é o rompimento entre o tempo e o espaço de aprendizagem e o espaço de que o ato de trabalhar ocupa na formação do trabalhador. A ideia de que primeiro uma pessoa se forma em um ambiente educativo e depois se qualifica por meio do mundo do trabalho perdeu quase todo o sentido. Hoje se vê o processo de formação do trabalhador como contínuo e sistemático, acompanhado de constantes transformações do mundo do trabalho. Cumpre mencionar Nikolas Rose (2001, p.35), para quem "o foco não é, portanto, a história da pessoa, mas a genealogia das relações que os seres humanos têm estabelecido consigo mesmos, isto é, as práticas nas quais eles se relacionam consigo mesmos como eus".

Paradoxalmente, a evolução das dinâmicas tecnológicas em relação às práticas do trabalho - e ao trabalhador - provocou considerável aumento de desemprego e restringiu seriamente a possibilidade de retornar em 
condições adequadas ao mercado de trabalho, alterando e promovendo as adaptações que o trabalhador precisa vivenciar para manter-se nas relações sociais do capitalismo.

A dinâmica evolutiva da tecnologia é preocupação permanente dos estudiosos da relação homem-trabalho. Nilton Vargas (1983) descreve com propriedade essa intervenção e modificação na relação produtiva desse trabalhador:

A tecnologia passou a articular o conhecimento científico com o conhecimento produtivo. Em outros termos, a articular as leis da natureza com as leis do capital. Esse "novo trabalhador", fruto da racionalização do tempo, invade a discussão atual, sendo subordinado a esse fator (p.62).

Parece-nos evidente que o atual entusiasmo tecnológico da sociedade capitalista, uma vez que - sob as mais diversas formas produtivas - a tecnologia visa ao trabalho e maximiza as limitações humanas, acentua a subordinação do trabalhador no processo de acumulação capitalista, aumentando a tensão no bojo da relação entre capital e trabalho pela excelência competitiva no trabalho. Essa lógica reafirma a necessidade do trabalhador modelado para as relações capitalistas e com possibilidades de alternar as atividades no mundo do trabalho.

A reflexão meadiana enseja pensar que vários selves coabitam um self global por meio do qual as alterações no campo social afetam a individualidade da pessoa, passando sua singularidade a conter o universal. Alterado pela dinâmica capitalista, o "eu" do trabalhador é reconstruído na convivência social, produzindo ações que evidenciam a mudança no self e no comportamento do trabalhador.

\section{A inscrição do "eu" na Psicologia Social: Em busca do "eu" trabalhador?}

A busca de superar a concorrência provocou alterações significativas na relação do trabalhador. Em contato com os escritos de Mead, revi minha noção sobre nós mesmos e passei a ver-nos como pessoas (self) vitaissociais cultivadas - "por meio da emoção e da linguagem", nas palavras de Silvia Lane, e pela cultura e consciência da sociedade que nos precedeu, propõe Sandoval. Sociedade, a propósito, mediatizada por "outros significativos" e por "outros generalizados", composta, entretanto, por pessoas (self) que, integradas por um "eu" e um "mim”, são um "mesmo" que integra, pela reflexão da linguagem, um "eu" vital-pessoal para um "mim" pessoal-social. Dessa indissociação "eu" e "mim" é possível pensar o surgimento do "eu" trabalhador? Ainda que reafirmemos o surgimento de uma nova categoria do "eu", agora o "eu" trabalhador é o conhecimento, sinônimo da transformação do sujeito, termo que Mead utiliza para pôr em evidência as transformações socioculturais da formação humana numa perspectiva da mudança social pela qual passa o trabalhador em busca da materialidade que, numa relação dialética, transforma para ser transformado, procedente das relações dos trabalhadores produtivos. Farr (2008), pensando Mead, distingue que:

A individualização é o resultado da socialização, e não sua síntese. O self nos seres humanos deve ser compreendido tanto filogeneticamente, em termos de evolução da espécie, como ontogeneticamente, em termos de desenvolvimento de cada membro individual da espécie (p.80).

A noção de pessoa está ligada à de sociedade e é direta a relação do "eu" trabalhador com os espaços produtivos que atuam sobre ele. Essa relação do "eu" trabalhador com o espaço produtivo enseja um "eu" diferente e com características próprias, como performance competitiva, disposto ao trabalho e com sentido de resiliência, ${ }^{2}$ espírito de equipe mas com capacidade para a delação, entre outros. Portanto, é nas práticas do cotidiano que as tramas da relação entre o "eu" e o "mim" da pessoa se estruturam para constituir a consciência do trabalhador. Nessa convergência, destaca-se "o fato social total", em que as dimensões da

\footnotetext{
${ }^{2}$ Entende-se por resiliência a capacidade do ser humano de recuperar-se psicologicamente quando submetido a adversidade, violência ou catástrofes na vida.
} 
manifestação do "eu" criam uma ligação entre o desenvolvimento físico, o psíquico e o social, numa rede complexa traduzida pelas suas práticas, o que faz lembrar o real sentido da "noção de pessoa" trazida por Mead, em que ao conceituar o self remete à autonomia do sujeito diante do controle da sociedade e sua capacidade de decisão em agir no campo pessoal e político (Sant'ana, 2004). Em Mead, observa Farr (2008), o self é resultante de um interacionismo simbólico em que a linguagem assume papel central na discussão da constituição desse "eu" na psicologia social.

Cumpre lembrar a importância de Mead para a legitimação da psicologia como relação social e não apenas como nascente das ciências naturais. Ao contrário de alguns pensadores, Mead evocou a mente como processo de investigação na constituição do self, transformando-se num "pragmático filosoficamente sofisticado". Por ser pensador da obra descartiana, também viveu as inquietações do dualismo corpo e mente, questionando amiúde "como os pensamentos podem dar origem às ações?"

Esse dualismo condicionou o que Mead viria a chamar de dualismo entre o self e o outro. Assim, o self emerge da interação social e o outro exerce o papel fundamental para nós mesmos e o reflexo psíquico resulta do movimento dialético da atividade objetivada por meio da qual o indivíduo entra em contato com o mundo circundante. "Nesse movimento o indivíduo apropria-se dos objetos materiais e também dos significados sociais mediatizadores dos vínculos entre o sujeito e o mundo" (Silva, 1986, p.49). O self surge das profundezas do humano e não como algo dado da experiência humana, isto é, processos simbólicos construídos. Como aponta Sant'ana (2004, p.27) ao discutir o self, Mead distingue o "eu" e o mim, concebendo o "eu" "como a fase do self que se exterioriza, em resposta às atitudes dos outros, enquanto o "mim" é a fase do self que internaliza aquelas atitudes" e ambos articulados resultam no self elaborado.

As inovações no contexto das relações sociais ganham espaço na medida em que consideram a convivência humana o ingrediente inerente da evolução social. Tornou-se importante considerar que os novos conhecimentos não se reduzem a máquinas, equipamentos e processos, mas incorporam de forma essencial aqueles que as operam e diferenciam a sociedade atual, alterando significativamente o psiquismo das pessoas. Por que parecemos desfocados do sentido evolutivo do psiquismo? Repensar abordagens complexas como a relação dialética do trabalho com os trabalhadores tornase imperioso neste século de mudanças para assegurar a sustentabilidade pessoal e social e indagar coletivamente: o seu trabalho é com sentido?

Os comportamentos humanos incorporam-se ao "eu" trabalhador no cotidiano mediante a formação do self. Embora não seja possível individualizar a ação de cada um dos termos propostos por Mead na formação humana - "eu", "mim" e self -, essa triangulação constitui a característica "unificadora" de cada pessoa a partir das mudanças ocorridas no campo social. Tais mudanças alteram o protótipo do trabalhador, em busca dos objetivos construídos por uma sociedade que ensina que ser é ter e que as relações afetivas e sociais são construídas sobre bases de trocas. Característica dos tempos modernos, a individualização devora a capacidade de construir o bem comum, o espaço comum de convivência, convergindo invariavelmente para o singular, o egoísmo e o individualismo das necessidades construídas, em que os fins justificam os meios.

\section{Considerações finais}

Inquietudes. Eis o painel que se descortina aos nossos olhos. Revisitar essas concepções do "eu", self e "mim" preconizadas por Mead requer reposicionar valores e comportamentos antes construídos para determinar a busca da sustentabilidade no campo social, mas para quê? Que sujeitos estão envolvidos? Nessa linha não muito linear, cabe destacar a revisão do papel concorrencial dos sujeitos, suas identidades contrárias aos valores de cooperação e, portanto, pensar e repensar a capilaridade que assumem as decisões nos ambientes produtivos, comunitários ou mesmo familiares na construção desse mosaico de relações humanas.

Dessas interconexões, na medida em que o conhecimento materializado obtém espaço e voz, resulta um eu do trabalhador. Entretanto 
é nas práticas em que se sustenta o processo de valorização nas relações subjetivas e intersubjetivas da criação do conhecimento, ou seja, na relação entre o trabalho abstrato e o trabalho coletivo em que esse trabalhador se inscreve que emerge a possibilidade de outra identidade, apontada neste século XXI de transformações críticas no capitalismo industrial e de efervescentes mutações sociais.

Nas primeiras décadas do século XX, trabalhar em organizações industriais do Primeiro Mundo era extremamente sacrificante. Da Era Moderna, surge um individualismo capaz de estabelecer elementos para um eu individualizado? Seria esse novo eu trabalhador resultante do individualismo moderno de que nos fala Dumont (1985)? Explora ele um valor e um "indivíduo" cujo objetivo está fora e além de si próprio, indivíduo cognitivo e falante, como caracterizado na evolução social. Da outra parte, aquele cuja moral rege suas ações, possuído de valores e de ideologia, "essencialmente não social".

É esse trabalhador produtivo do "admirável mundo novo" que abre mão da vida social para consagrar-se na racionalidade do progresso e determinar seu próprio destino? Justificam-se jornadas de mais de doze horas (às vezes ininterruptas), absoluta falta de segurança e qualidade da saúde no trabalho, salários baixos, nenhuma garantia de justiça social e uma relação de extrema competitividade entre os próprios trabalhadores: eis o panorama de que provêm as insatisfações históricas vivas até hoje na memória dos trabalhadores. Memórias que constituem a construção de um self trabalhador individualizado. Seriam reminiscências desse trabalhador dos primórdios da era pré-capitalista, ou mesmo capitalista para o eu trabalhador deste século? Inquietações! Examinando o cenário do século passado, as condições não parecem distantes das atuais, como revelam fatos que marcam a sociedade do trabalho do século XXI.

Dizer que surge um "eu" trabalhador dessa nova relação homemtrabalho seria lançar suspeita de que tempos sombrios reapresentam um "eu" exteriorizado diferente? Não seriam essas "novas" relações as já vistas no passado, agora mediadas e transformadas pelo avanço tecnológico? Mas de que ser humano estamos falando? Seria um self que permite legitimar as condições sociais e de trabalho, modelando um protótipo de trabalhador flexível, adaptável às empresas do "futuro"?

Por terem sido de extrema angústia e privação, tais experiências e memórias dos trabalhadores foram transmitidas geração após geração, o que constitui a consciência de si como mediadora para a constituição do mim. Esse "eu" estaria aqui expresso na relação do espelho quando o self passa a permitir e legitimar as mudanças ocorridas com o "mim" e na explicitação do "eu", no caso em discussão o trabalhador quando no ato de trabalhador, na interação social. Entre o prescrito e o previsto, cresce o abismo na relação entre capital e trabalho e ergue-se uma barreira real entre os interesses do capitalista e do trabalhador na qual os meios de produção passam a prevalecer sobre o self individualizado, produzindo um self coletivo que permite alterar e maximizar as formas de expansão do capitalismo mediadas pelo capitalismo imaterial cujo aporte de discussão é o conhecimento gerado pelo trabalhador.

Vale dizer que o status dos espaços produtivos em termos competitivos e de valor de mercado é resultado de um conjunto de variáveis, entre as quais o conhecimento tácito, muitas vezes associado ao inconsciente de cada pessoa como intangível das relações entre os seres que rege a dialética capitalista. É desse conhecimento interno que o self reelabora, por intermédio do mim, um eu trabalhador capaz de suportar as capturas do capitalismo e, a partir delas, a captura da consciência, instalando uma "falsa consciência".

Vivemos numa economia do conhecimento, num capitalismo cognitivo em que o trabalho abstrato e social dos sujeitos é fruto de uma energia intelectual e linguística capaz de produzir bens intangíveis. Esse conhecimento é capturado pela mente - self-, que processa tudo o que lhe é atribuído por meio externo, o eu que revela o trabalhador.

A mente, aqui, inclui a capacidade de aprender e usar a mediação simbólica para atingir a inter-relação entre os sujeitos no meio social, na 
construção da identidade e da consciência. Dessa forma, pode-se interpretar a prática da atividade humana como a construção inteligente de seres humanos por meio da interação social entre os sujeitos e os artefatos símbolos - que compõem a trama produtiva.

No cotidiano das relações entre o trabalhador e o trabalho e das consequências que os envolvem diariamente, a formação do "eu" trabalhador pode ser modificada na sua construção ou, não raro, ser negada pela relação social. Isso costuma acontecer quando a satisfação da vida não é vivenciada pelos seres humanos e acaba por desequilibrar a evolução social das espécies. Trata-se de perguntar ontologicamente: de onde viemos e para onde vamos?

A subjetividade negada no mundo do trabalho se fortalece pelo desrespeito à dignidade do trabalhador, obrigando-o a converter desejos em valores ou a sucumbir à estrutura dominante, obrigando-o a tornar-se mecanismo de produção, desconsiderando sua condição humana, merecedor de benefícios e satisfações acordados ou mesmo conquistados. Nesse cenário de incertezas, a formação do "eu" trabalhador não subsiste em base tão frágil e efêmera, desprovida de elementos capazes de transpor o inesperado, de competências que separam, paradoxalmente, as incoerências da vida.

É essencial compreender a relação bilateral - "eu"-sociedade - que constitui a noção de pessoa do "eu" trabalhador no modelo emergente da sociedade capitalista. A retórica do paradigma emergente nas relações sociais destaca a importância da criação dessa relação "intersubjetiva". $\mathrm{Na}$ relação desenhada nos cenários produtivos, os trabalhadores são chamados a integrar essa dinâmica capitalista para contribuir numa relação de trocas econômicas, políticas e sociais.

Não há certezas diante do conflito clássico que opõe o trabalhador e o trabalho, cenário cotidiano de todos os que trabalham e deixa perplexos os estudiosos da sociedade no mundo do trabalho. Importa preparar-se para lidar com a instabilidade, o que vale dizer estar apto para tomar decisões, ressignificar conceitos, atitudes e comportamentos.
$\mathrm{Na}$ relação trabalhador-trabalho, as características inconstantes e flexíveis tomam proporções assustadoras. Seu desenvolvimento humano self - não é mais possível à medida que as fragilidades da sociedade capitalista introduzem nas relações produtivas a negação do outro pela competitividade e à medida que individualiza o "eu" trabalhador como sinônimo de sobrevivência por meio das mudanças nos comportamentos.

Deixou de ser possível o eu que se satisfaz com sua história de vida numa relação socialmente construída na presença do outro. Assim, a busca pela satisfação no acontecimento produtivo do cotidiano é ir e vir constante, um construir para desconstruir e reconstruir quase instantaneamente pela negação do outro. O “eu” não deveria ser investigado como um espaço contido de individualidade humana, "limitado pelo envelope da pele, que foi precisamente a forma como, historicamente, ele acabou por conceber sua relação consigo mesmo", como ensina Rose (2001, p.144).

Escreve Rose, (2008) "o self é para aspirar autonomia, para esforçarse para alcançar satisfação pessoal em sua vida na terra" (p.162). Retomar a questão do sentido do trabalho na vida de cada trabalhador - a formação do eu trabalhador com um trabalho digno - parece ser o primeiro passo. A tentativa de negar a perda do eu, a ausência da noção de coletivo ou mesmo do outro, de partilha no sentido mais amplo da palavra "comunitário" constitui para alguns a razão da falência ou da perda da esperança desse eu trabalhador.

Equacionar a questão da relação trabalhador-trabalho que nasce do clássico conflito capitalista capital $x$ trabalho exige desconstruir o sistema para focalizar o humano, despertar sonhos, encantar a vida e reinventar saídas que reproponham o coletivo como o centro dessa discussão. Dessa forma, mantém na dobradura do cotidiano das práticas produtivas do eu trabalhador a certeza da vida, ainda que admitamos, como Foucault, não existirem verdades gerais que modelem o eu trabalhador pela racionalidade que conduz a constatações e replicações gerais, mas que o que existe é a arqueologia humana do viver (Fonseca, 2003) na construção do humano, segundo Silvia Lane, transpassado pela emoção e pela linguagem na sua formação. 
A discussão acerca desse "olhar" crítico sobre a atividade humana trabalho - no espaço social para a construção do "eu" trabalhador é muito complexa. Cumpre lembrar que a noção do social trazida para o ensaio não se resume ao espaço e às possibilidades de sociabilidades entre os sujeitos aqui os trabalhadores - nas fábricas, mas abrange a forma em que tais relações acontecem, não como um social predeterminado ou mesmo prescrito, mas a "trama" pela qual constrói o trabalhador a partir da prática do "uso de si" em que ele próprio executa sua atividade e com que vai se constituindo ao longo da sua história, num processo de subjetivação constante e na articulação dos saberes. Busca-se sair da simplificação trazida pelo viés econômico como única resposta ao sentido do trabalho. Outro desafio é pensar o trabalho como uma via de acesso para entender o social, remetendo quase sempre à forma de organização do processo produtivo como uma variável determinante para a observação sobre a complexidade do trabalho, que contraria o ato de trabalhar, uma vez que as múltiplas relações e estruturas do cotidiano podem revelar a diferenciação do humano.

\section{Referências bibliográficas}

Bendassolli, P. F. (2007) Trabalho e identidade em tempos sombrios. Aparecida, São Paulo: Ideias e Letras.

Beserra, F. de M. et.al. (2004) A contribuição da teoria de Leontiev no estudo da relação entre trabalho e educação. www.abrapso.org.br. Acesso em 03.07.2011.

Bock, A. M. B. e Gonçalves, M. da G. M. (Org.). (2009) A dimensão subjetiva da realidade: uma leitura sócio-histórica. São Paulo: Cortez.

Braverman, H. (1987) Trabalho e Capital Monopolista. Rio de Janeiro: Guanabara.

Dumont, L. (1985) Do indivíduo-fora-do-mundo ao indivíduo-no-mundo. In: Dumont, L. O Individualismo (pp.35-71). Rio de Janeiro: Rocco.
Farr, R. (2008) George Herbert Mead, filósofo e psicólogo social. In: . As raízes da psicologia social moderna. Petrópolis: Vozes.

Fonseca, M. (2003) A disciplina como estratégia política. In: Michael Foucault e a constituição do sujeito (pp.39-71). São Paulo: Educ.

Furtado, O. e Rey, F. L. G. (2002) Por uma epistemologia da subjetividade: um debate entre a teoria sócio-histórica e a teoria das representações sociais. São Paulo: Casa do Psicólogo.

Gorz, A. (2003) Metamorfoses do Trabalho: crítica da razão econômica. São Paulo: Annablume.

. (2004) L'immateriale, Conoscenza, Valore e Capitale. França: Multitudes.

Heller, A. (2000) O Cotidiano e a História. $6^{\text {a }}$ Ed., São Paulo: Paz e Terra.

Marx, K. (1975) O Capital. São Paulo: Abril Cultural, Vol. 2.

Mead, G. H. (1993) Parte III: La Persona. Capítulos 18, 19, 20, 21, 22, 29. In: . Espíritu, persona y sociedad: desde el punto de vista del conductismo social. México: Paidós.

Moscovici, S. (2010) Representações Sociais: investigações em psicologia social. Petrópolis: Vozes.

Ribeiro, M. A. (2004). A trajetória no mundo do trabalho: o conceito de carreira. In: Orientação profissional para "pessoas psicóticas": um espaço para o desenvolvimento de estratégias identitárias de transição através da construção de projetos (pp. 83-105). Tese de Doutorado, Programa de Estudos Pós-Graduados em Psicologia Social e do Trabalho, Universidade de São Paulo, São Paulo, SP.

Rose. N. (2008) Psicologia como uma ciência social. Universidade de Londres, Psicologia \& Sociedade, 20 (2), 155-164. 
(2001) Como se deve fazer a história do eu? Educação \& Realidade. Porto Alegre, 26 (1), jan./jun, 34-57.

(2001) Inventando nossos eus. In: Silva, T. T. da (Org.). Nunca fomos humanos: nos rastros dos sujeitos (pp.137-204). Belo Horizonte: Autêntica

(1998) Governando a alma: a formação do eu privado. In: Silva, T. T. da (Org.) Liberdades reguladas (pp.30-45). Petrópolis: Vozes.

Sandoval, S. A. M. (1989) Consideração sobre aspectos microssociais na analise dos movimentos sociais. Psicologia e Sociedade, 7, 61-89.

(1989) A crise sociológica e a contribuição da psicologia social ao estudo dos movimentos sociais. Educação e Sociedade, 34, 122-130.

(1994) Os trabalhadores param. Greves e mudança social no Brasil: 1945-1990. São Paulo: Ática.

(1994) Algumas reflexões sobre cidadania e formação de consciência política no Brasil. In: Spink, M. J. (Org.). A cidadania em construção: uma reflexão transdisciplinar. São Paulo: Cortez.

Sant'ana, R. B. de. (2004) O processo de formação do sujeito e o self na psicologia social de G. H. Mead. Revista de Psicologia Política, jan/jun, 4 (7).

Silva, R. (2004) Notas para uma Genealogia da Psicologia Social. UFRGS, Psicologia \& Sociedade, 16 (2), maio/ago.

Silva, M. N. (1986) A produção social da consciência: uma abordagem histórica da consciência como fenômeno psíquico. Dissertação Mestrado em Educação. Campinas: Unicamp.

Varga, N. (1983) Gênese e difusão do taylorismo no Brasil. São Paulo: Cortez/ANPOCS.
Xavier, R. (2002) Representação social e ideologia: conceitos intercambiáveis? Psicologia \& Sociedade, 14 (2), jul/dez. 


\section{Sobre os Autores e as Autoras}

\section{Antônio Fernando Gomes Alves}

Doutorando do Programa de Estudos Pós-Graduados em Psicologia Social da Pontifícia Universidade Católica de São Paulo, Núcleo de Pesquisa Psicologia Política e Movimentos Sociais. Possui graduação em Ciências Econômicas pela Universidade São Francisco (1992) e Filosofia pelo Instituto Santo Tomás de Aquino (1998). Especialização em História, Sociedade e Cultura pela Pontifícia Universidade Católica de São Paulo (1998) e Mestrado em Economia Política PUC/SP (2000). É professor titular da Universidade São Judas Tadeu e da Universidade Municipal de São Caetano do Sul. Tem experiência na área de Economia e Administração, com ênfase em Economia e Psicologia do Trabalho, Psicologia Política, Políticas e Finanças Públicas, Educação, Aprendizagem Organizacional e Gestão do Conhecimento.

E-mail: prof_alves@uol.com.br

\section{Beatriz Akemi Takeiti}

Doutoranda do Programa de Estudos Pós-Graduados em Psicologia Social da Pontifícia Universidade Católica de São Paulo, Núcleo de Pesquisa em Lógicas Institucionais e Coletivas. Possui graduação em Terapia Ocupacional pela Pontifícia Universidade Católica de Campinas (2000) e Mestrado em Psicologia Social pela Pontifícia Universidade Católica de São Paulo (2003). É Professora Assistente do Curso de Terapia Ocupacional do Centro Universitário São Camilo. Tem experiência em atividades de ensino, pesquisa e extensão na área de Fisioterapia e Terapia Ocupacional, com ênfase no Campo Social, atuando principalmente nos seguintes eixos: infância e adolescência em situação de vulnerabilidade e desfiliação social, jovens autores de ato infracional, população em situação de rua, ações territoriais, educação e violência.

E-mail: biatakeiti@gmail.com

\section{Emanoel José Batista de Lima}

Doutorando do Programa de Estudos Pós-Graduados em Psicologia Social da Pontifícia Universidade Católica de São Paulo, Núcleo de Pesquisa em Lógicas Institucionais e Coletivas. Possui graduação (2000) e licenciatura (2001) em Psicologia pela Universidade Federal do Rio Grande do Norte e Mestrado em Psicologia pela Universidade Federal do Rio Grande do Norte (2005). É professor da Faculdade Santo Agostinho e professor-assistente da Universidade Estadual do Piaú, atuando principalmente nos seguintes temas: saúde coletiva, saúde mental, reforma psiquiátrica, violência, jovens, adolescentes, recursos comunitários.

E-mail: emano_lima@yahoo.com

\section{Fernando Fernandes Pimenta}

Doutorando do Programa de Estudos Pós-Graduados em Psicologia Social da Pontifícia Universidade Católica de São Paulo, Núcleo de Estudos e Pesquisas sobre Identidade-Metamorfose. Possui graduação em Administração de Empresas pela Escola Superior de Administração de Negócios (1979), Mestrado em Psicologia (área: Psicanálise) pela Universidade São Marcos (2006), MBA em Recursos Humanos pela Fundação Getúlio Vargas (2009), Formação em Psicanálise pelo Centro de Estudos Psicanalíticos (2005) e em Personal and Executive Coach pelo Integrated Coaching Institute (2009). Experiência profissional no Brasil, Argentina e USA em Administração Geral, Finanças, Marketing e Gestão de Pessoas. Coach de Executivos e de Vida. É professor universitário em cursos de graduação e MBA.

E-mail: fernando.f.pimenta@gmail.com 


\section{Heli de Andrade}

Doutorando do Programa de Estudos Pós-Graduados em Psicologia Social da Pontifícia Universidade Católica de São Paulo, Núcleo de Trabalho e Ação Social. Possui graduação em Engenharia Mecânica-Aeronáutica pelo Instituto Tecnológico de Aeronáutica (ITA-1988), Pós-Graduação em Administração de Empresas pela Fundação Getúlio Vargas (SP-1991) e Mestrado em Administração pela Stanford University (USA-1998). Experiência profissional nas áreas de Finanças e de Administração, com ênfase em Gestão de Cultura e Transformação Cultural em Organizações.

E-mail: heliade@uol.com.br

\section{José Estevam Salgueiro}

Doutorando do Programa de Estudos Pós-Graduados em Psicologia Social da Pontifícia Universidade Católica de São Paulo, Núcleo de Trabalho e Ação Social. Possui graduação em Psicologia pela Pontifícia Universidade Católica de São Paulo (1978) e Mestrado em Educação, Arte e História da Cultura pela Universidade Presbiteriana Mackenzie (2003). É professor no curso de Psicologia da Universidade Presbiteriana Mackenzie e do lato sensu na mesma IES. Trabalha principalmente nos seguintes temas: subjetividade e trabalho, psicologia institucional e psicologia organizacional e do trabalho. Experiência profissional em Psicologia Organizacional (Recursos Humanos), como técnico, gestor e consultor.

E-mail: estevamsalgueiro@uol.com.br

\section{Jullyane Chagas Barboza Brasilino}

Doutoranda do Programa de Estudos Pós-Graduados em Psicologia Social da Pontifícia Universidade Católica de São Paulo, Núcleo de Estudos e Pesquisas em Práticas Discursivas e Produção de Sentidos. Possui graduação em Psicologia pela Universidade Federal de Pernambuco (2006) e Mestrado em Psicologia pelo Programa de Pós-Graduação em Psicologia da Universidade Federal de Pernambuco (2010). É integrante do GEMA Núcleo de Pesquisas em Gênero e Masculinidades/UFPE. Tem experiência na área de Psicologia, com ênfase em Psicologia Social. Pesquisando atualmente sobre violência contra a mulher, gênero e judicialização das relações conjugais.

E-mail: jullyanebrasilino@gmail.com

\section{Mary Jane Paris Spink}

Possui graduação em Psicologia pela Universidade de São Paulo (1969) e doutorado em Psicologia Social - University of London (1982). É professora titular da Pontifícia Universidade Católica de São Paulo, Programa de Estudos Pós-graduados em Psicologia Social. Tem experiência na área de Psicologia, com ênfase em Psicologia Social, atuando principalmente nos seguintes temas: práticas discursivas e produção de sentidos, risco como estratégia de governamentalidade e saúde coletiva.

E-mail: mjspink@pucsp.br 


\section{Patrícia do Prado Ferreira-Lemos}

Doutoranda do Programa de Estudos Pós-Graduados em Psicologia Social da Pontifícia Universidade Católica de São Paulo, Núcleo Psicanálise e Sociedade. Possui graduação em Psicologia pela Universidade Estadual Paulista (UNESP-2003), Especialização em Psicologia Clínica pela PUCRio (2005) e Mestrado em Psicanálise, Saúde e Sociedade na Universidade Veiga de Almeida (2009). Tem experiência em pesquisa, clínica e formação contínua em Psicanálise, atuando principalmente nos temas: psicanálise, cultura, sujeito, ciberespaço, laços sociais.

E-mail: patricia.ferreiralemos@gmail.com

\section{Pedro Paulo Viana Figueiredo}

Doutorando do Programa de Estudos Pós-Graduados em Psicologia Social da Pontifícia Universidade Católica de São Paulo, Núcleo de Estudos e Pesquisas em Práticas Discursivas e Produção de Sentidos. Possui graduação em Psicologia pela Universidade Federal de Pernambuco (2007) e Mestrado em Psicologia pelo Programa de Pós-Graduação em Psicologia da Universidade Federal de Pernambuco (2010). Têm experiência na área de Psicologia, com ênfase em Psicologia Social, pesquisando principalmente nos temas: violência contra criança, segurança da criança no trânsito, psicologia social discursiva e retórica.

E-mail: pedro.vfigueiredo@gmail.com

\section{Sheila Ferreira Miranda}

Doutoranda do Programa de Estudos Pós-Graduados em Psicologia Social da Pontifícia Universidade Católica de São Paulo, Núcleo de Estudos e Pesquisas sobre Identidade-Metamorfose. Possui graduação em Psicologia (bacharelado e licenciatura) pela Universidade Federal de São João Del Rei (2006) e Mestrado em Psicologia pela mesma Universidade (2009). É docente da Universidade Presidente Antônio Carlos. Tem experiência na área de Psicologia, com ênfase em Psicologia Social, atuando principalmente nos seguintes temas: identidade, grupos comunitários, oficinas, processo grupal, desigualdade social, violência e afro-descendência no Brasil.

E-mail: sheilaze@gmail.com 